SELECTED WATER-QUALITY CHARACTERISTICS AND FLOW OF GROUND WATER

IN THE SAN LUIS BASIN, INCLUDING THE CONEJOS RIVER SUBBASIN, COLORADO AND NEW MEXICO

By Robert S. Williams, Jr., and Stephen E. Hammond

U.S. GEOLOGICAL SURVEY

Water-Resources Investigations Report 89-4040

Denver, Colorado

1989 
DEPARTMENT OF THE INTERIOR

MANUEL LUJAN, JR., Secretary

U.S. GEOLOGICAL SURVEY

Dallas L. Peck, Director

For additional information write to:

District Chief

U.S. Geological Survey

Box 25046, Mail Stop 415

Federal Center

Denver, CO 80225-0046
Copies of this report can be purchased from:

U.S. Geological Survey Books and Open-File Reports Section Federal Center

Box 25425

Denver, CO 80225-0425

[Telephone: (303) 236-7476] 
Abstract-1-0

Introduction--1-0

Purpose and scope-1-0.-1

Physical and geohydrologic setting--

Previous studies-0.-

Description of the data base-1

Wells and springs-0.

Water quality-0.-

Selected water-quality characteristics and flow of ground water-.......

Water type-1.

Dissolved-solids concentrations-1-n

Water temperature and fluoride concentrations-

Tritium concentrations--

Future ground-water information needs--

Summary and conclusions-0.-

References cited-1

Supplemental water-quality data-

PLATE

Plate 1. Map showing location of wells and springs for which chemical analyses are available, San Luis basin, Colorado and New Mexico.

\section{FIGURES}

Figure 1. Map showing location of the San Luis basin, extent of the

2. Map showing physiographic subdivisions in the San Luis basin

3-5. Graphs showing:

3. Monthly mean precipitation at Alamosa, Colo., 1951-70-...-

4. Monthly mean snowfall at Alamosa, Colo., 1951-70-.-.---

5. Monthly mean maximum and mean minimum air temperatures at Alamosa, Colo., 1951-70-10

6. Map showing location of wells and springs in the Conejos River subbasin-.-1 11

7. Diagrammatic geohydrologic section along the Conejos River-- 12

8. Hydrograph showing frequency distribution of the ionic balance--- 14

9-11. Maps showing:

9. Water types in the unconfined aquifer (less than 100 feet deep) in the Colorado part of the San Luis Valley--.---

10. Water types in the confined aquifer (more than 100 feet deep) in the Colorado part of the San Luis Valley--.--

11. Areal distribution of dissolved-solids concentrations in the unconfined aquifer (less than 100 feet deep) in the Colorado part of the San Luis Valley-.-

12. Diagrammatic geologic section along the Conejos River---- 


\section{TABLES}

Table 1. Well and spring sample sites and sample sources in the

Page

Conejos River subbasin-- 10

2. Selected water-quality characteristics of wells and springs in the Conejos River subbasin- 17

3. Selected water-quality characteristics of springs in the New Mexico part of the San Luis basin- 20

4. Water-quality information from selected wells and springs in the San Luis basin in Colorado and New Mexico-a. 28

5. Water-quality information from selected wells and springs in the Conejos River subbasin in Colorado-

\section{CONVERSION FACTORS}

Inch-pound units used in this report may be converted to metric (International System) units by using the following conversion factors:

$\begin{array}{lc}\text { Multiply } & B y \\ \text { foot (ft) } & 0.3048 \\ \text { inch (in.) } & 25.4 \\ \text { mile (mi) } & 1.609 \\ \text { gallon per minute (gal/min) } & 0.06308\end{array}$

To obtain

meter millimeter $(\mathrm{mm})$ kilometer liter per second $(\mathrm{L} / \mathrm{s})$

Temperature in degree Celsius $\left({ }^{\circ} \mathrm{C}\right)$ can be converted to degree Fahrenheit $\left({ }^{\circ} \mathrm{F}\right)$ as follows:

$$
{ }^{\circ} \mathrm{F}=9 / 5\left({ }^{\circ} \mathrm{C}\right)+32
$$

Temperature in degree Fahrenheit $\left({ }^{\circ} \mathrm{F}\right)$ can be converted to degree Celsius $\left({ }^{\circ} \mathrm{C}\right)$ as follows:

$$
{ }^{\circ} \mathrm{C}=5 / 9\left({ }^{\circ} \mathrm{F}-32\right)
$$

The following terms and abbreviations also are used in this report: $\mathrm{mg} / \mathrm{L}$, milligram per liter; $\mu \mathrm{g} / \mathrm{L}$, microgram per liter; $\mu \mathrm{S} / \mathrm{cm}$, microsiemens per centimeter at 25 degrees Celsius.

Sea level: In this report "sea level" refers to the National Geodetic Vertical Datum of 1929 (NGVD of 1929)--a geodetic datum derived from a general adjustment of the first-order level nets of both the United States and Canada, formerly called Sea Level Datum of 1929. 


\title{
SELECTED WATER-QUALITY CHARACTERISTICS AND FLOW OF GROUND WATER IN THE SAN LUIS BASIN, INCLUDING THE CONEJOS RIVER SUBBASIN, COLORADO AND NEW MEXICO
}

By Robert S. Williams, Jr., and Stephen E. Hammond

\begin{abstract}
Chemical analyses of water from 99 wells and 19 springs in the San Luis basin in Colorado and New Mexico were evaluated to determine selected waterquality characteristics as an aid in understanding the flow of ground water in the basin. The evaluation shows that the distribution of chemical water types in the basin is consistent with chemical changes to be expected along flow paths in rocks typical of those in the basin.

The San Luis basin area is underlain by a surficial (less than 100 feet thick) unconfined aquifer and, in turn, by a confining bed and a deeper confined aquifer. Previous studies have indicated that the ground-water system is recharged around the edges of the basin and that ground water then moves toward discharge areas in the topographically closed part of the basin and along principal streams. Results of this ground-water-quality evaluation support these previously developed concepts of flow through the aquifer system in the San Luis basin.
\end{abstract}

\section{INTRODUCTION}

The San Luis basin, in southern Colorado and northern New Mexico, was included in the Southwest Regional Aquifer System Analysis (SWRASA) program. The objective of the RASA program is to assemble geologic, hydrologic, and geochemical information, to analyze and develop an understanding of the aquifer system, and to develop predictive methods that contribute to effective management of the aquifer system. The SWRASA study involves parts of Colorado, New Mexico, and Texas. The San Luis basin was included as part of the SWRASA program to assess selected ground-water-quality characteristics and, if possible, to use these characteristics as a means to determine source and direction of ground-water flow.

The study of the San Luis basin was designed to fulfill the following objectives :

1. Screen existing water-quality data from the U.S. Geological Survey WATSTORE files (Hutchison, 1975);

2. Determine the areal distribution of water types and selected water-quality characteristics in the basin;

3. Determine sources and direction of ground-water flow; and

4. Determine guidelines for future ground-water information needs in the basin. 
The purposes of this report are to:

1. Describe the screening procedure used to evaluate water-quality data in the WATSTORE files and to tabulate data for selected waterquality characteristics. All data for each selected sample are tabulated and included in the "Supplemental Water-Quality Data" section at the back of this report.

2. Describe the water types, based on percent composition of major ions, present in the shallow aquifer system (less than $100 \mathrm{ft}$ deep) and the deep aquifer system (more than $100 \mathrm{ft}$ deep). Additional waterquality characteristics, including dissolved-solids concentration, water temperature, and concentrations of fluoride and tritium, also are described.

3. Describe the change in ground-water quality as ground water flows from areas of recharge to areas of discharge.

This report presents information about two major parts of the San Luis basin, the closed basin and the Conejos River subbasin. The discussion of the hydrogeology of the New Mexico area is minimal because available data are few. The hydrogeology of the San Luis basin has been studied by many investigators, but they have concentrated on the closed basin (as discussed in the "Previous Studies" section). The Conejos River subbasin was emphasized in this report because it is vital hydrologically for inflows to the Rio Grande, and because information about this area has not been reported extensively.

The WATSTORE file (Hutchison, 1975) contains information on 486 water samples collected from 1940 to 1985 . The samples represent 367 separate sampling sites.

\section{Physical and Geohydrologic Setting}

The San Luis basin is located in parts of nine counties in south-central Colorado and two counties in north-central New Mexico (fig. 1). In Colorado, the basin is bounded primarily by the Culebra Range and Sangre de Cristo Mountains to the east and the Cochetopa Hills and the San Juan Mountains to the west. The western boundary primarily is delineated by the Continental Divide. In New Mexico, the basin is bounded by the Sangre de Cristo Mountains to the east and in part coincides with the Taos and Rio Arriba County lines to the west.

The San Luis Valley is the part of the San Luis basin adjacent to the Rio Grande and its major tributaries (fig. 1). The valley is about 125 to $150 \mathrm{mi}$ long and $50 \mathrm{mi}$ wide; it is flanked by the San Juan Mountains to the west and the Sangre de Cristo Mountains to the east. The San Juan Mountains and the Sangre de Cristo Mountains meet at the northern end of the valley and form a northern boundary. The southern boundary of the valley is not well defined and has been arbitrarily set about $15 \mathrm{mi}$ south of the Colorado-New Mexico border by Siebenthal (1910). 


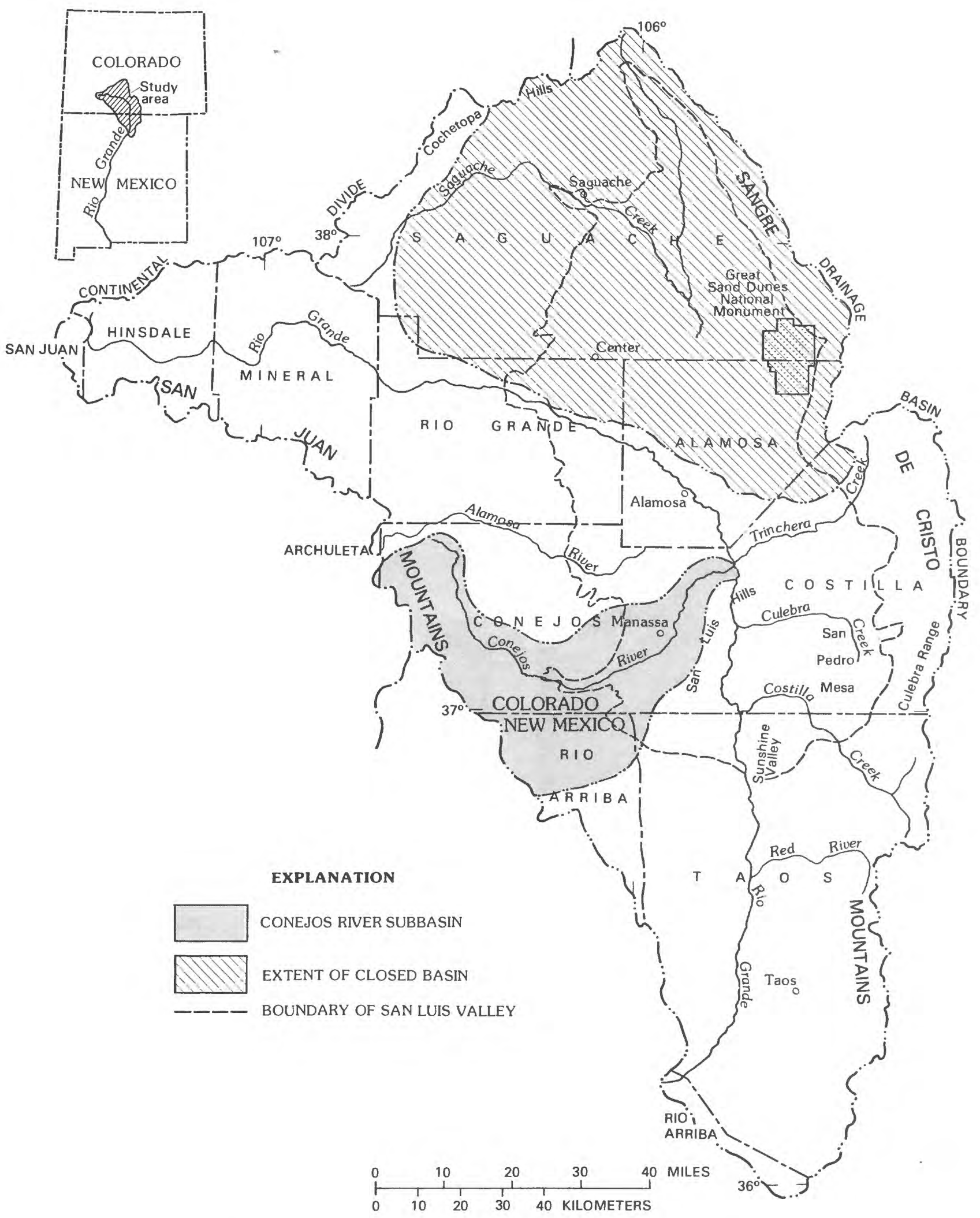

Figure 1.--Location of the San Luis basin, extent of the closed basin, and location of the San Luis Valley. 
The physiographic setting of the San Luis basin has been described in various reports. The San Luis basin contains the San Luis Valley in southcentral Colorado and the Taos Plateau in north-central New Mexico. The basin is a structural depression that lies between the Sangre de Cristo Mountains to the east and the San Juan Mountains to the west (Burroughs, 1981). Upson (1939) subdivided the basin into five physiographic provinces--the Alamosa Basin, the San Luis Hills, the Taos Plateau, the Costilla Plains, and the Culebra Reentrant (fig. 2).

The San Luis basin has an arid to semiarid climate. Mean annual air temperature at Alamosa is $6^{\circ} \mathrm{C}$; mean annual precipitation is 7 in.; mean annual snowfall is 36 in. The data are based on 20 years of record from 1951 to 1970 (ENMAP Corporation, 1981). Monthly mean precipitation for Alamosa, Colo., is shown in figure 3; monthly mean snowfall is shown in figure 4; monthly mean maximum and mean minimum air temperatures are shown in figure 5 (ENMAP Corporation, 1981). The dry environment and prevailing southwesterly winds facilitated development of sand dunes in Great Sand Dunes National Monument, located in parts of Saguache and Alamosa Counties.

West of Alamosa, in the San Juan Mountains, the mean annual air temperature is $3{ }^{\circ} \mathrm{C}$; mean annual precipitation is 41 in.; mean annual snowfall is 364 in. These data indicate that the San Juan Mountains have a cooler and wetter climate than does the San Luis basin. Because of the larger quantity of rain and snow and the lower air temperature, much of the ground-water recharge and surface-water discharge originates in the mountains that surround the valley floor of the basin.

Agriculture is a major use of water in the basin. Irrigated areas receive water from ground- and surface-water sources. Water in the basin in New Mexico primarily is used for domestic purposes, but some water is used for agriculture.

A significant geologic feature that affects the hydrology of the San Luis basin in Colorado is a confining clay layer that occurs throughout large parts of the basin (Emery and others, 1973, p1. 2). This clay layer separates an unconfined aquifer from a confined aquifer.

North of Alamosa, water in the shallow unconfined aquifer flows within a topographically closed basin where evapotranspiration losses are the major discharge from the ground-water system, and dissolved-solids concentrations may exceed $30,000 \mathrm{mg} / \mathrm{L}$ (see tables 4 and 5 in the "Supplemental Water-Quality Data" section at the back of this report). Water from the surface and from the unconfined aquifer does not flow out of the closed basin. Some water from the confined aquifer may flow out of the closed basin.

The headwaters of the Conejos River are in the San Juan Mountains. After leaving the mountains, the river generally flows northeasterly along the western side of the San Luis Hills. The Conejos River joins the Rio Grande near the northern extent of the western San Luis Hills. The river generally is losing water to ground water in its upper reaches and gaining water from ground water in its lower reaches (E.L. Nickerson, U.S. Geological Survey, written commun., 1986). 


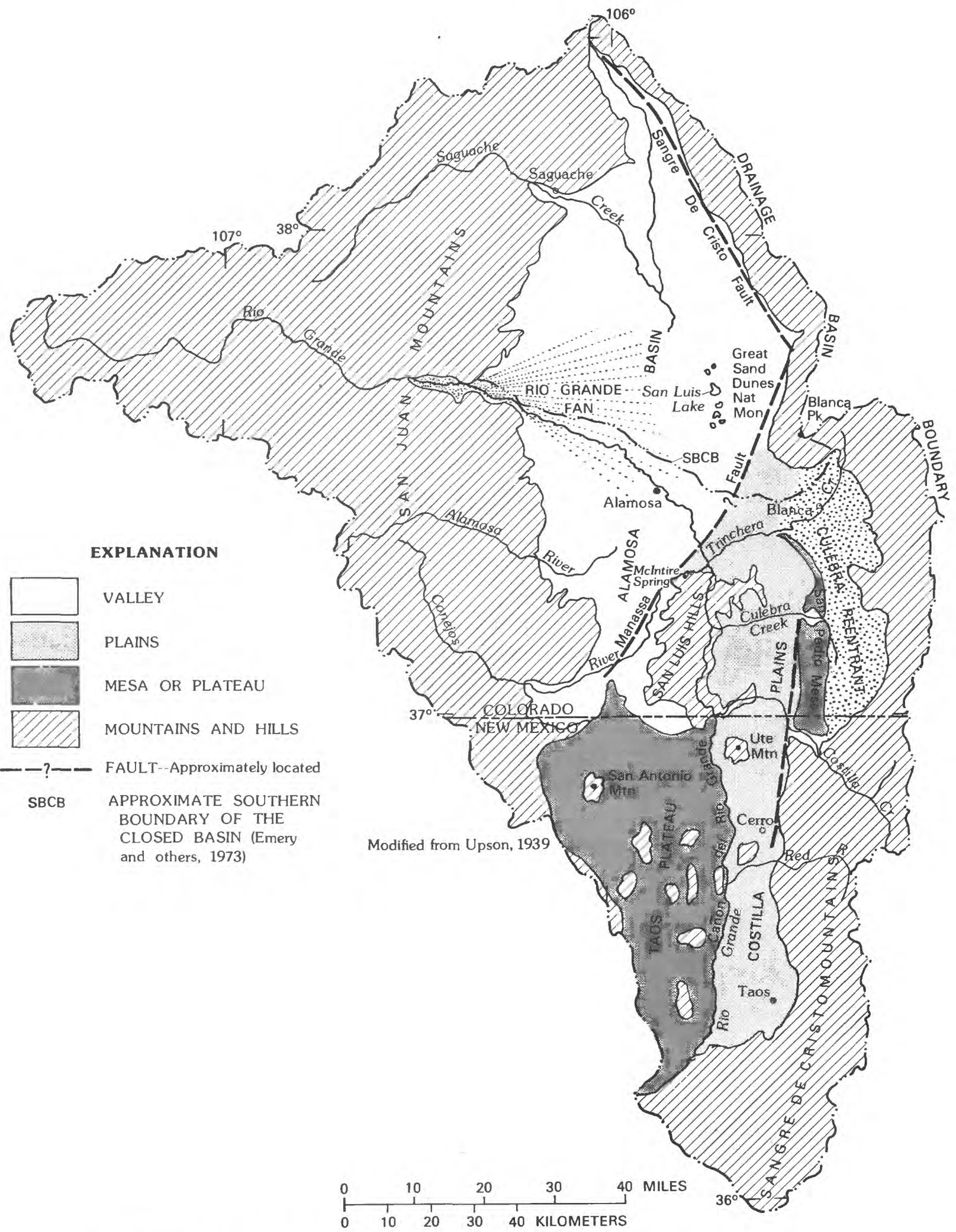

Figure 2.--Physiographic subdivisions in the San Luis basin (modified after Upson, 1939). 


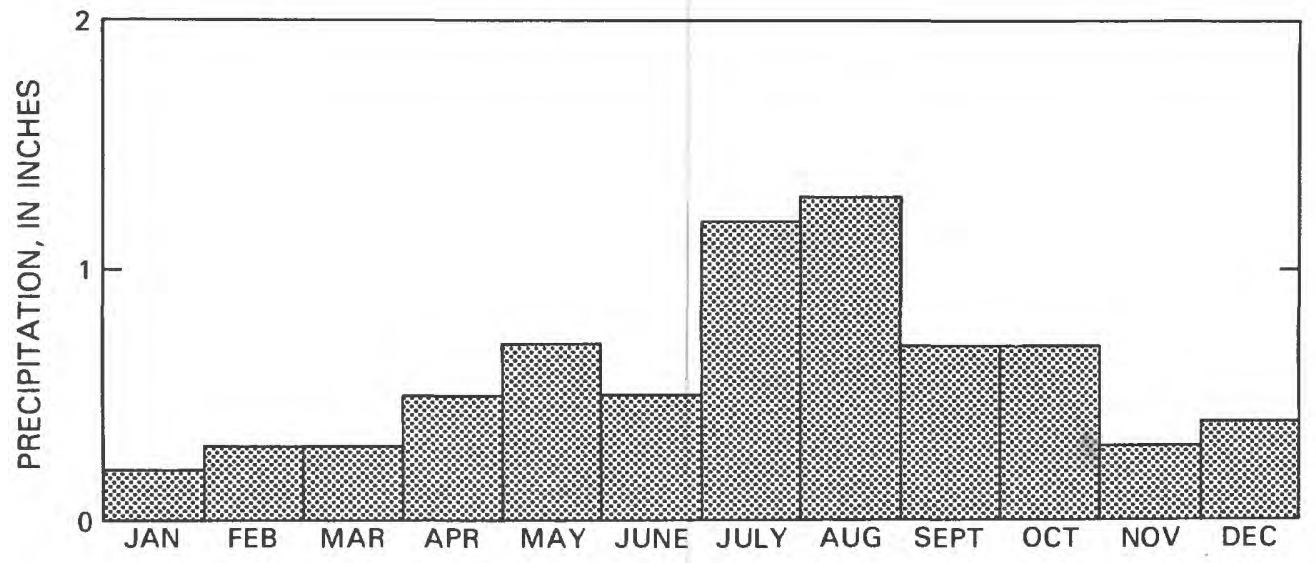

Figure 3.--Monthly mean precipitation at Alamosa, Colo., 1951-70.

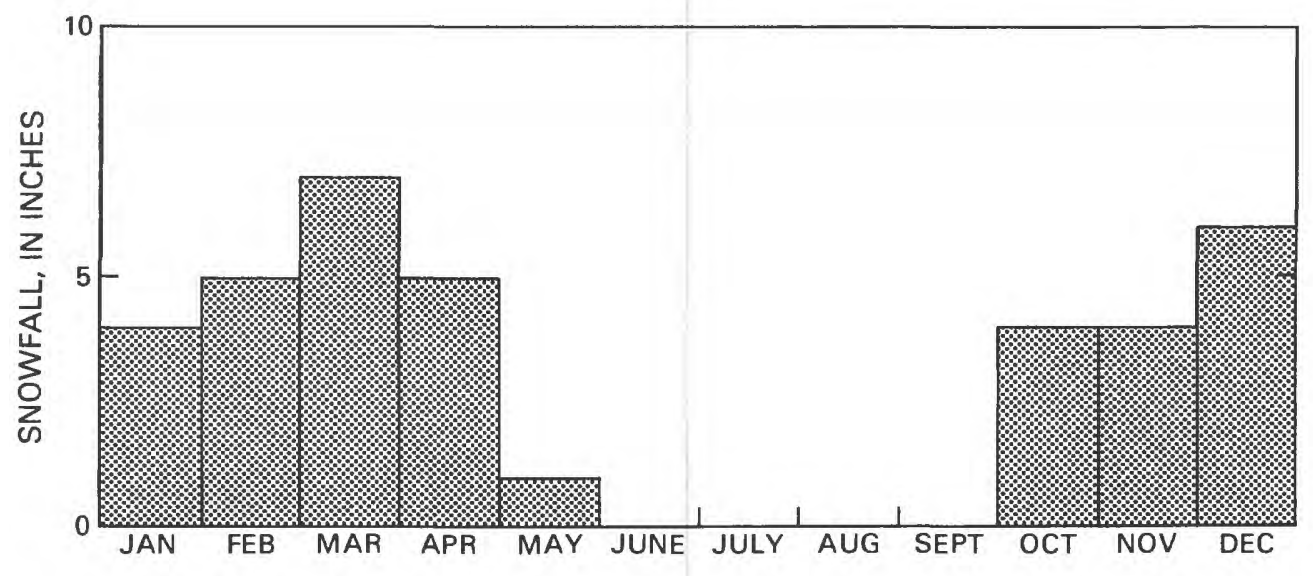

Figure 4.--Monthly mean snowfall at Alamosa, Colo., 1951-70. 


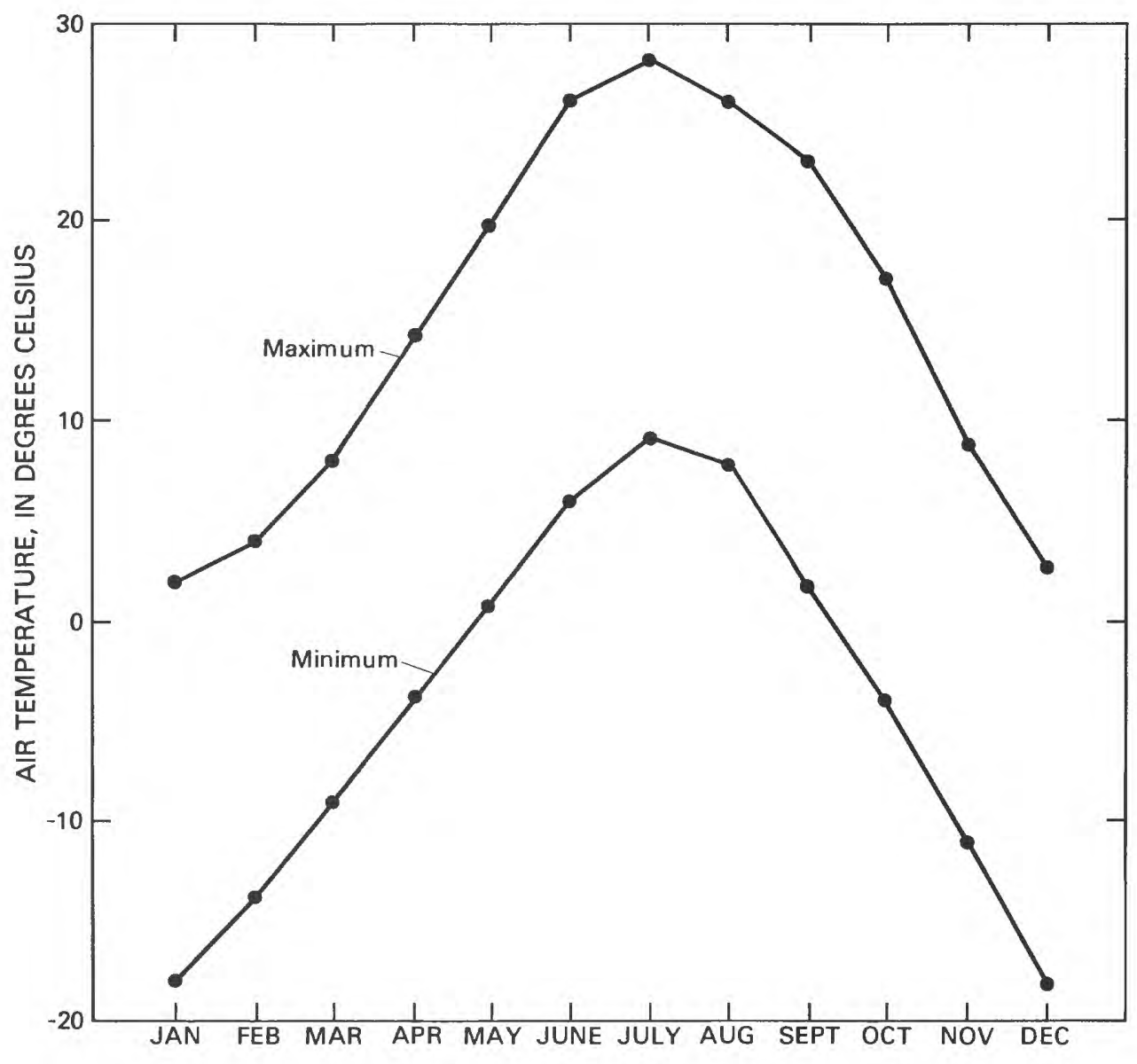

Figure 5.--Monthly mean maximum and mean minimum air temperatures at Alamosa, Colo., 1951-70.

The Conejos River flows over unconfined and confined aquifers. Emery and others (1973, pl. 2) approximated the extent of a confining clay layer that has southern limits near Manassa, Colo. (fig. 1). Emery and others (1973) also reported approximate depth to the uppermost lava flow in this same area, which is the principal confining unit. Gravel beds are interbedded with lava flows, forming a lava-gravel complex that is recharged near the outcrops of the lava. The water then flows downgradient either through the lava flows, the grave1, or both. Potentiometric contours for the area indicate that ground-water generally flows northeasterly toward McIntire Spring (fig. 2) (Emery and others, 1973, p1. 6; Crouch, 1985). Lava flows in the same area tend to dip to the north, indicating that water in the lava moves deeper as it flows north.

A fault, commonly known as the Manassa fault (fig. 2), lies somewhat parallel to the Conejos River near the San Luis Hills. This fault, or other attendant faults, may allow upward leakage from the confined aquifer to the many springs in the area. 


\section{Previous Studies}

The closed basin (fig. 1) north of Alamosa was studied in detail by Huntley (1976), who divided the basin and nearby mountains into three distinct but hydrologically connected regions. The Sangre de Cristo Mountains were considered a region of relatively low, depth-dependent permeability, and the San Juan Mountains and the San Luis Valley, where the closed basin is located, were considered regions of moderate to high permeability. Huntley (1976) stated that:
"Ground-water recharge to the western San Luis Valley is primarily from ground-water flow in the volcanic rocks of the San Juan Mountains. Ground-water recharge to the eastern valley is primarily from seepage of surface water into the upper parts of the alluvial fans bordering the eastern edge of the valley."

Huntley also indicated that the limit of the flowing wells in the San Luis Valley did not correspond to the limit of the confining clays. Because of the interconnection of aquifers in the San Luis Valley, Huntley also noted that development of one aquifer would affect other aquifers. Huntley noted that, while bicarbonate was the major anion throughout the closed basin, the major cation changed from calcium in areas of recharge along the basin margins to sodium near the center of the basin. This change in the predominant cation mainly resulted from cation exchange on the clays. Huntley used ratios of calcium to sodium to define the lateral extent of the confining layers, and he noted that the change from calcium to sodium along the eastern margin of the closed basin resulted from hyperfiltration through the confining clay. Hyperfiltration results when water driven by hydraulic head flows through a semipermeable membrane, and ionic solutes remain on the input side of the membrane.

Emery and others (1971, 1972, 1973, 1975) described the closed basin and the Colorado part of the San Luis basin. These reports presented data, described hydrology and water availability, and documented an electric-analog model of ground-water flow in the valley. Huntley's (1976) findings mostly agreed with the findings of these reports. One difference in interpretation between the reports was that Huntley indicated that the confining clay extended farther to the east than Emery and others predicted. Huntley noted that chemical evidence and a gradual eastward thickening of the entire clay series might imply that the clays terminated at the Sangre de Cristo fault (fig. 2). Emery and others $(1971,1972,1973,1975)$ assumed the clays ended 4 or $5 \mathrm{mi}$ west of the Sangre de Cristo fault.

More recent work in the valley includes a report by Edelmann and Buckles (1984) that describes the quality of ground water in agricultural areas in the San Luis Valley. The authors determined that the chemical quality of ground water in the area generally is suitable for domestic and agricultural uses. However, water from the unconfined aquifer near Center, Colo. (fig. 1), contained excessive concentrations of dissolved nitrite plus nitrate as nitrogen (33 $\mathrm{mg} / \mathrm{L})$, because of recharge from irrigated fields. Dissolved nitrate as nitrogen that exceeds $10 \mathrm{mg} / \mathrm{L}$ in a drinking-water supply can harm infants younger than 3 months old (U.S. Environmental Protection Agency, 1986). However, excessive nitrogen concentrations can be beneficial to crops as fertilizer. 
Edelmann and Buckles (1984) also determined that large concentrations of dissolved solids occur in some areas. The salinity hazard associated with the water in those areas can decrease crop yields. The authors noted that the "...high salinity hazard in ground water seems to occur in those areas where evapotranspiration from a shallow water table and leaching of salts by recirculation of applied water may be concurrently concentrating the dissolved solids in the ground water." A sodium hazard also existed in some areas that had large dissolved-solids concentrations. Without careful management practices, use of water having a high sodium hazard can decrease crop yields severely.

Burroughs (1981) evaluated the hydrogeology and the quality of water from the confined aquifer in Colorado and New Mexico. He noted that the confined aquifer was composed of volcanic, volcaniclastic, and other rocks, and that it was located between the confining clay series and the basement Precambrian rocks. Dissolved-solids concentrations that occur at depths of 5,304 to $5,491 \mathrm{ft}$ were about $4,000 \mathrm{mg} / \mathrm{L}$. Chloride concentrations ranged from 2,800 to $3,100 \mathrm{mg} / \mathrm{L}$.

The most comprehensive evaluation of the New Mexico part of the San Luis basin was made by Winograd (1959). His work primarily focused on the Sunshine Valley and the area in western Taos County. The report evaluated the availability and occurrence of ground water in conjunction with the geology of the area. Ground-water quality in alluvial sediments in the Sunshine Valley (fig. 1) in New Mexico was evaluated based on data from nine wells (Winograd, 1959). Dissolved-solids concentrations were less than $200 \mathrm{mg} / \mathrm{L}$, and the water did not contain excessive concentrations of trace elements. Water from lava deposits also was sampled at three spring sites and one stock well. The quality of water in these materials was similar to the quality of water in alluvial sediments. Dissolved-solids concentrations ranged from 144 to 155 $\mathrm{mg} / \mathrm{L}$. In general, the water was acceptable for domestic and irrigation uses.

\section{DESCRIPTION OF THE DATA BASE}

Only data readily available from the U.S. Geological Survey WATSTORE computer data file (Hutchison, 1975) were used in this report. Well depth and specific chemical constituents were used as criteria for selecting results of analyses so that a consistent set of water-quality data were available for evaluation. The WATSTORE file contains data for 486 samples collected from 1940 to 1985 . The samples represent 367 separate sampling sites. Fifty-three of the samples are from springs, and the remainder are assumed to be from wells.

\section{Wells and Springs}

The depth of a well is indicative of the aquifer sampled. The location of perforated intervals in the well casing and the method of well completion also can help determine the source of the water sampled. However, the WATSTORE file did not contain information about the method or zone of completion for most wells. If a well is completed in more than one aquifer, or if the well is assumed to be completed in one aquifer when it actually is 
completed in two aquifers, mixing of aquifer waters can result, and interpretation of the geochemistry may be misleading or false. For this report, the wells were assumed to be completed in only one aquifer, either the unconfined aquifer above the clay layer or the confined aquifer below the clay layer. Wells less than $100 \mathrm{ft}$ deep are assumed to be completed in the unconfined aquifer, and wells more than $100 \mathrm{ft}$ deep are assumed to be completed in the confined aquifer. Reported depth of the well is assumed to be the depth from which water was sampled; only 149 wells had well-depth information.

To help understand the hydrology of the Conejos River subbasin, two of the springs, McIntire Spring and Dexter Warm Spring, were investigated, as were nearby wells tapping the aquifers that may yield water to the springs. The depth of the wells was assumed to approximate the depth from which the wells are drawing water. McIntire Spring is located beside the San Luis Hills along the Conejos River and near the Manassa fault (fig. 6). WATSTORE-file data were combined with data collected for this study to help understand the ground-water flow system near McIntire Spring (table 1). Data from wells completed in the confined aquifer (sites $21,22,24,32$, and E, fig. 7), the unconfined aquifer (sites 23 and 26, fig. 6), and Dexter Warm Spring (site 31, fig. 6) were used to evaluate interactions between McIntire Spring and the nearby aquifers. Sites $21,22,23$, and 24 are designated as upgradient sites to sites 26, 27 (McIntire Spring), 31 (Dexter Warm Spring), 32, and E, which are designated as downgradient sites (fig. 6). Although well 26 probably is not in the flow path downgradient from the other wells (fig. 6), data from the well are included in the data set because it is the only well completed in the unconfined aquifer near McIntire Spring. The assumption is made that the quality of water from the well is typical of water from the unconfined aquifer near the San Luis Hills.

Table 1.--Well and spring sample sites and sample sources in the Conejos River subbasin

[--, no new samples collected]

\begin{tabular}{ccl}
\hline $\begin{array}{c}\text { Site- } \\
\text { observation } \\
\text { number } \\
\text { (p1. fig. 6) }\end{array}$ & $\begin{array}{c}\text { Site- } \\
\text { observation } \\
\text { letter }\end{array}$ & \multicolumn{1}{c}{$\begin{array}{c}\text { Sample } \\
\text { source }\end{array}$} \\
\hline 21 & new sample, fig. 6) & \\
22 & -- & Confined aquifer \\
23 & A & Confined aquifer \\
24 & -- & Unconfined aquifer \\
26 & -- & Confined aquifer \\
27 & -- & Unconfined aquifer \\
31 & B,C & McIntire Spring \\
32 & D & Dexter Warm Spring \\
Confined aquifer
\end{tabular}

${ }^{1}$ At sites $A, B, C$, and $D$, new water samples were collected to supplement existing data available from WATSTORE; site $\mathrm{E}$ is a new sampling site. 


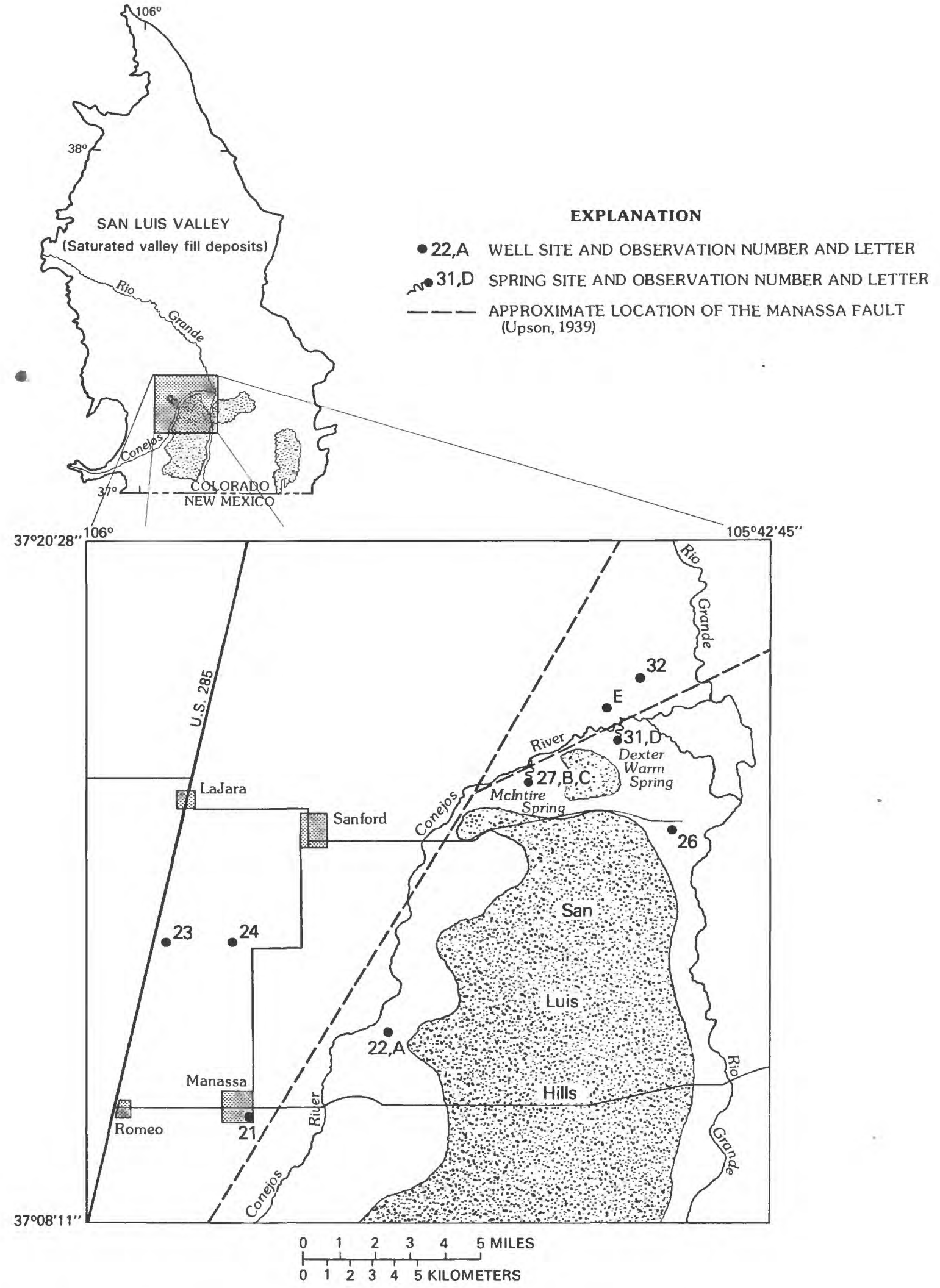

Figure 6.--Location of wells and springs in the Conejos River subbasin. 

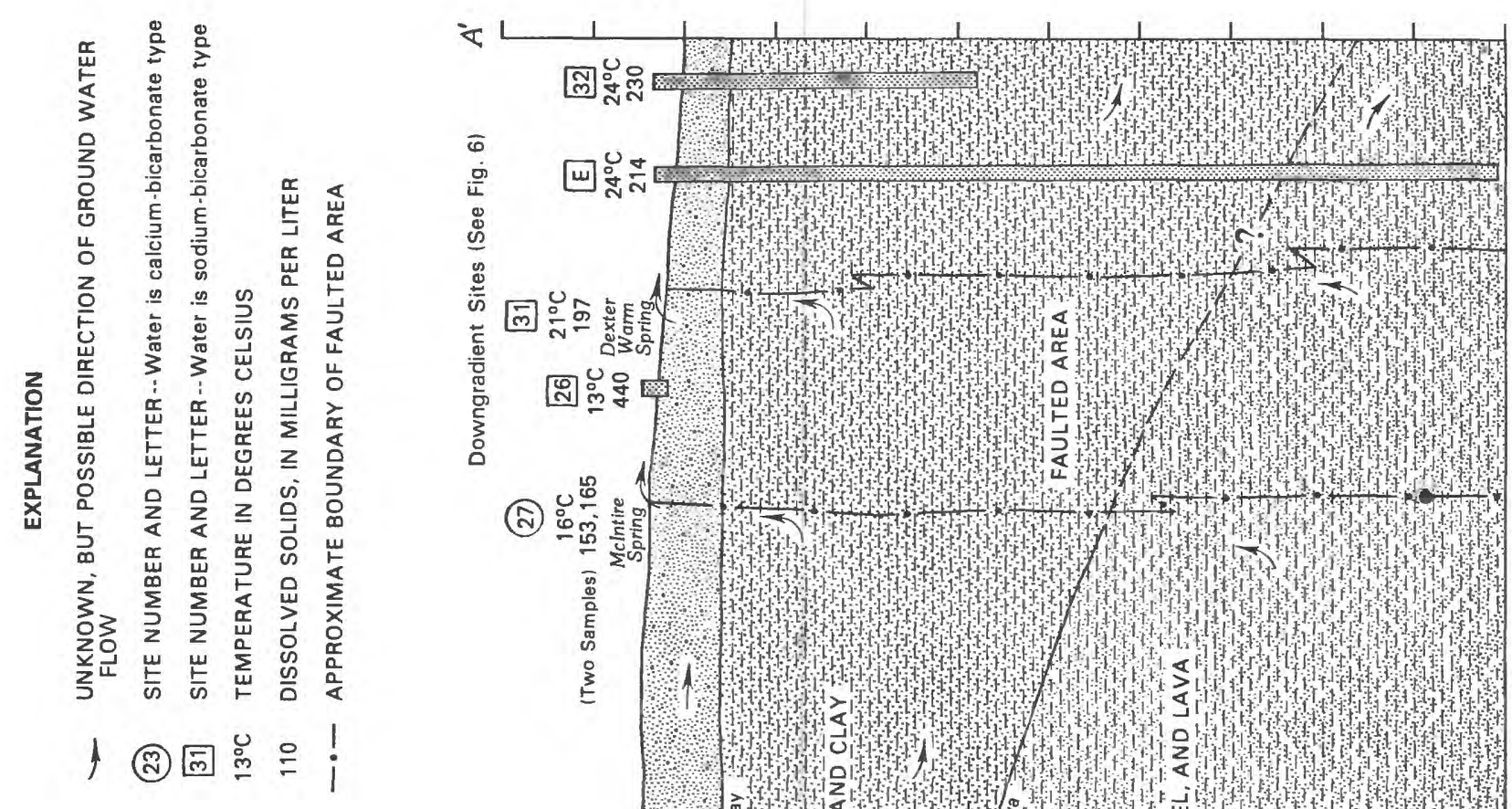

(a)
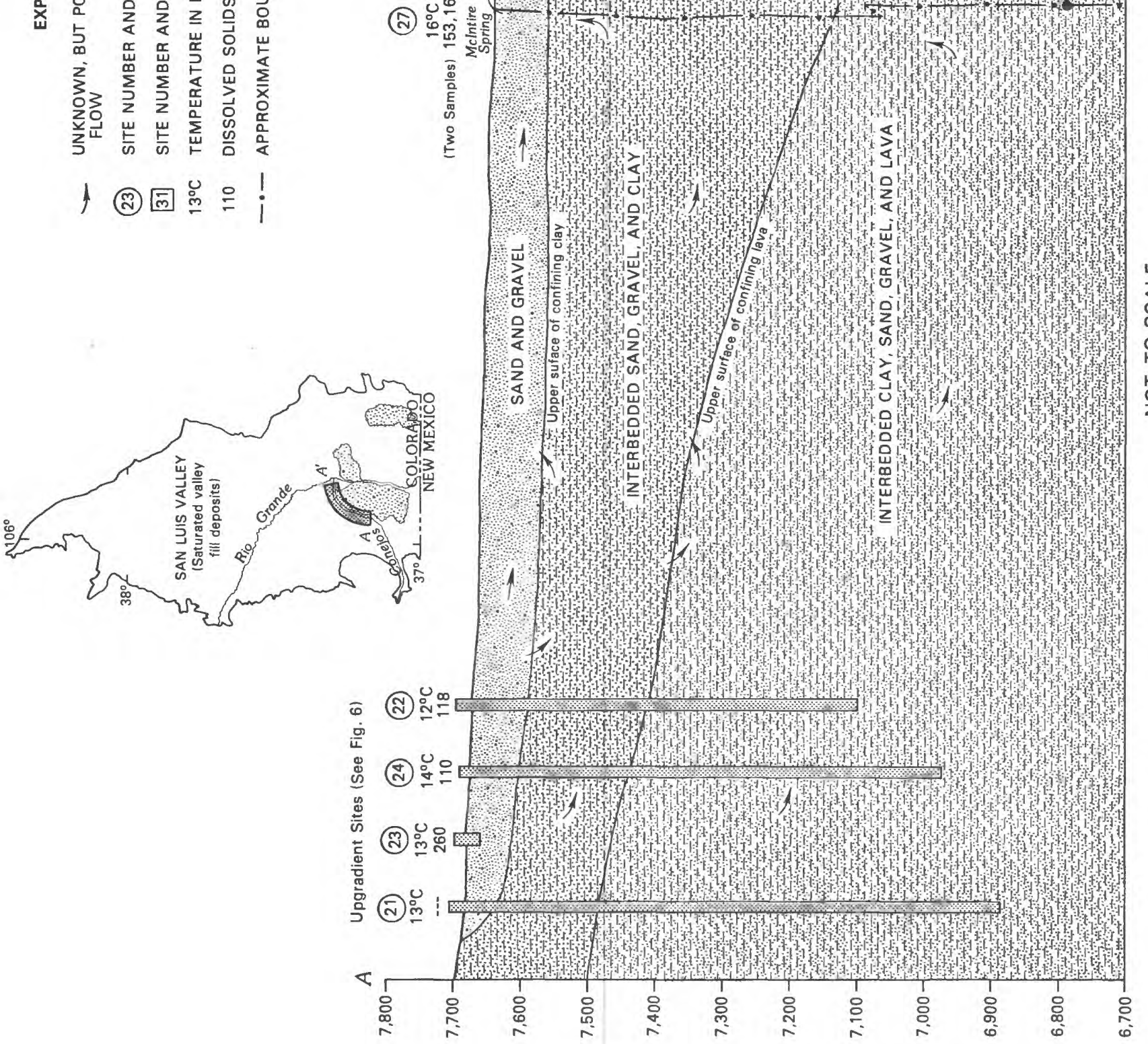

$7 \exists \wedge \exists 7 \forall \exists S \exists \wedge O 8 \forall \perp \exists \exists \exists$ NI ‘NOIL $\forall \wedge \exists 7 \exists$ 


\section{Water Quality}

Because previous studies in the basin had different objectives, waterquality information in the WATSTORE file has a large number of variables. Principal criteria for results of analyses to be used in this report were: (1) An acceptable ionic balance and (2) analyses for specific constituents deemed necessary for interpretation. Results of analyses were grouped into those for water from the unconfined aquifer and those for water from the confined aquifer, based on well depth. Some wells identified as being completed in the confined aquifer are located beyond the limit of the confining clay layer. Whether these wells actually tap the confined aquifer is not known. Data from the wells were included in the confined-aquifer grouping because the true limits of the confining clay layer are not known, and the wells are completed in deeper witer-bearing zones.

A sufficient number of major cations and anions had to be included in the results of analysis to calculate an ionic balance, where:

$$
\text { ionic balance }=[\text { (cations-anions) } / \text { (cationstanions) }] \times 100 \text {. }
$$

Sample analyses that had an ionic-balance difference larger than 10 percent were excluded from the data set; 13 analyses exceeded this limit. The histogram in figure 8 shows the frequency distribution of the analyses that have an ionic balance between -10 and +10 percent.

Each result of analysis was required to have measured values for temperature, $\mathrm{pH}$, calcium, magnesium, potassium, sodium, alkalinity or bicarbonate, chloride, fluoride, and sulfate. These constituents were deemed necessary for definition of water type and for interpretation of water-quality characteristics.

The final data set included results of 131 analyses that represented 118 sites (99 wells and 19 springs). Each of these results met the above criteria for evaluation. The location of each sampling site is shown on plate 1, and a complete listing of water-quality data is in tables 4 and 5 in the "Supplemental Water-Quality Data" section at the back of this report.

\section{SELECTED WATER-QUALITY CHARACTERISTICS AND FLOW OF GROUND WATER}

Evaluation of water-quality data can help describe the hydrology of an area. Differences in water quality can indicate that separate aquifers are present, or that water in a single aquifer is flowing from an area of recharge to an area of discharge. In general, water quality changes as water moves along a flow path. Major cations and anions present in ground water change as the water moves through the aquifer system. Chebotarev (1955) reported that ground water evolves chemically toward the composition of seawater as the water becomes older and flows downgradient in a sedimentary basin. Calcium bicarbonate type water generally has small dissolved-solids concentrations, and its presence generally indicates active movement of ground water; thus, the presence of calcium bicarbonate type water is typical in areas of recharge. Calcium sulfate type water generally is associated with larger 


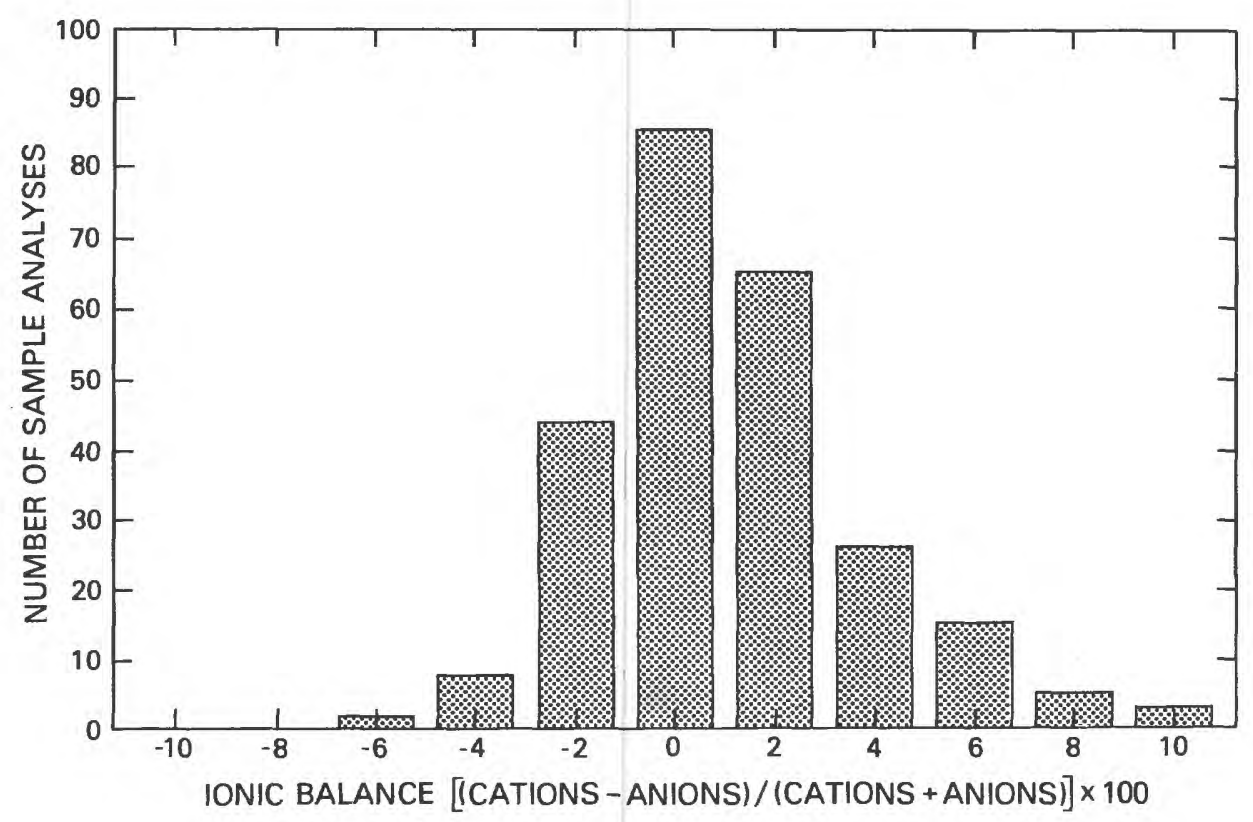

Figure 8.--Frequency distribution of the ionic balance.

dissolved-solids concentrations, as it is derived mostly from dissolution of readily soluble minerals such as gypsum. Calcium or sodium chloride type water. also is associated with larger dissolved-solids concentrations, and its presence may indicate little circulation of water.

\section{Water Type}

Huntley (1976) used schematic hydrochemical cross sections to indicate differences in the ratio of calcium to sodium in water from the unconfined and confined aquifers in the closed basin. He indicated that, as ground water flows toward the center of the San Luis basin, the ratio of calcium to sodium decreases, indicating that calcium is being replaced by sodium as the major cation.

Cation exchange and dissolution processes are likely to occur in the San Luis basin because water is flowing through carbonate minerals and clay deposits. Anion water type will change from bicarbonate to sulfate to chloride. Most of the water discussed in this report is a calcium or sodium bicarbonate water type.

Water types in the study area are shown in figures 9 and 10 . The confining clay is assumed to mark the boundary of the confined aquifer. In this report, for water to be considered dominated by a specific cation, that cation must be present at least 50 percent-by-composition in the water sample. 


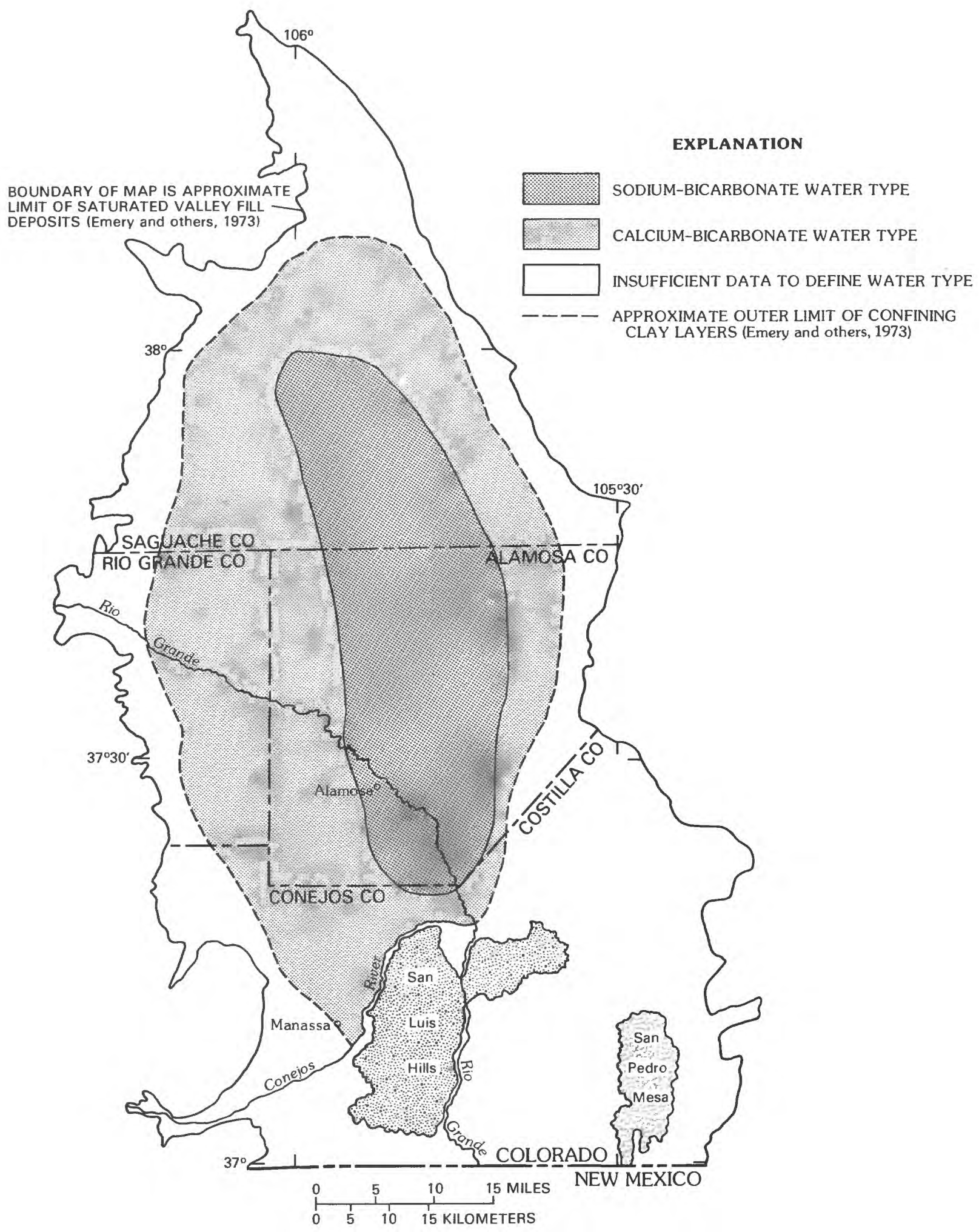

Figure 9.--Water types in the unconfined aquifer (less than 100 feet deep) in the Colorado part of the San Luis Valley. 


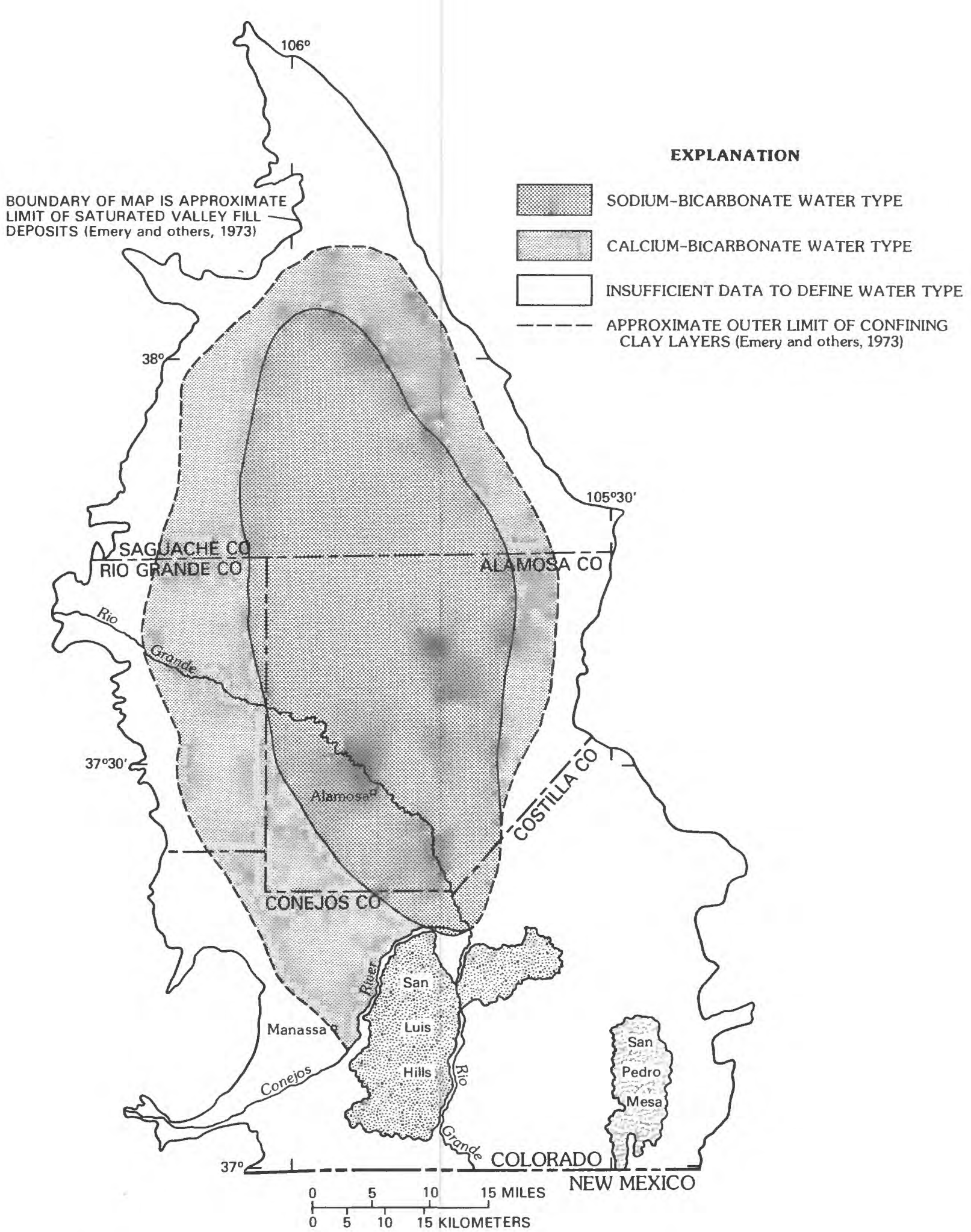

Figure 10.--Water types in the confined aquifer (more than 100 feet deep) in the Colorado part of the San Luis Valley. 
A fairly straightforward change in water type can be seen in figures 9 and 10: water at the perimeter of the basin primarily is a calcium bicarbonate type; water near the center of the basin primarily is a sodium bicarbonate type. This relation indicates the chemical evolution of ground water, and also indicates that flow is toward the center of the basin. The cation change probably is the result of cation exchange of calcium for sodium on clay minerals. This particular exchange is useful in the San Luis basin for depicting direction of ground-water flow.

Cation exchange of calcium for sodium on clay minerals is a process that is assumed to occur in the Conejos River subbasin, as in the rest of the San Luis Valley. Waters from upgradient wells are all calcium bicarbonate types. Waters from downgradient sites are all sodium bicarbonate types, except for McIntire Spring, which yields calcium bicarbonate type water (fig. 7). With the exception of McIntire Spring, the change in water type could be interpreted to be the normal chemical evolution of the ground water. Simply based on this information, the source of water for McIntire Spring could be assumed to be a point along a flow path related to the confined aquifer. Selected water-quality characteristics for wells and springs in the Conejos River subbasin are listed in table 2 .

Table 2.--Selected water-quality characteristics of wells and springs in the Conejos River subbasin

[ft, feet; mg/L, milligrams per liter; ${ }^{\circ} \mathrm{C}$, degree Celsius; --, no data]

\begin{tabular}{|c|c|c|c|c|c|c|c|}
\hline \multirow{2}{*}{$\begin{array}{l}\text { Site- } \\
\text { obser- } \\
\text { vation } \\
\text { number } \\
\text { or letter } \\
\text { (fig. 6) }\end{array}$} & \multirow[t]{2}{*}{$\begin{array}{r}\text { Date of } \\
\text { sample }\end{array}$} & \multirow[t]{2}{*}{$\begin{array}{l}\text { Sample } \\
\text { source }\end{array}$} & \multirow[t]{2}{*}{$\begin{array}{c}\text { Depth } \\
(\mathrm{ft})\end{array}$} & \multicolumn{2}{|c|}{$\begin{array}{l}\text { Water type } \\
\text { (percent } \\
\text { composition; } \\
\text { anion is } \\
\text { bicarbonate }\end{array}$} & \multirow[t]{2}{*}{$\begin{array}{l}\text { Dis- } \\
\text { solved } \\
\text { solids } \\
(\mathrm{mg} / \mathrm{L})\end{array}$} & \multirow[t]{2}{*}{$\begin{array}{l}\text { Tem- } \\
\text { pera- } \\
\text { ture } \\
\left({ }^{\circ} \mathrm{C}\right)\end{array}$} \\
\hline & & & & calcium & sodium & & \\
\hline 21 & $06-03-82$ & Confined aquifer & 806 & 61 & 13 & $\ldots$ & 13.0 \\
\hline 22 & $06-02-82$ & Confined aquifer & 575 & 162 & ${ }^{1} 17$ & ${ }^{1} 118$ & ${ }^{1} 12.0$ \\
\hline 23 & $09-10-68$ & Unconfined aquifer & 16 & 73 & 19 & 260 & 13.0 \\
\hline 24 & $08-08-68$ & Confined aquifer & 695 & 56 & 19 & 110 & 14.0 \\
\hline 26 & $09-09-68$ & Unconfined aquifer & 9 & 33 & 53 & 440 & 13.0 \\
\hline 27 & $04-19-76$ & McIntire Spring & -- & 154 & ${ }^{1} 26$ & ${ }^{1} 165$ & 16.0 \\
\hline 31 & $04-19-76$ & Dexter Warm Spring & -- & $1_{28}$ & ${ }^{1} 56$ & ${ }^{1} 197$ & 21.0 \\
\hline 32 & $08-19-68$ & Confined aquifer & 318 & 13 & 78 & 230 & 24.0 \\
\hline $\mathrm{E}$ & $05-03-84$ & Confined aquifer & ${ }^{1} 940$ & $1_{21}$ & ${ }^{1} 55$ & ${ }^{1} 214$ & 24.0 \\
\hline
\end{tabular}

${ }^{1}$ Indicates data calculated from, or listed in, table 5 of the "Supplemental Water-Quality Data" section. All other data are from table 4 in the "Supplemental Water-Quality Data" section. 


\section{Dissolved-Solids Concentrations}

Another indicator of water quality and ground-water-flow direction is dissolved-solids concentration. As ground water flows downgradient, additional minerals are dissolved until the water becomes saturated with respect to the rock minerals with which it is in contact. The dissolution process results in larger dissolved-solids concentration downgradient.

Dissolved-solids concentrations in water from the confined aquifer increase downgradient and with depth; however, the dissolved-solids concentration exceeded $500 \mathrm{mg} / \mathrm{L}$ in only one sample. By contrast, dissolved-solids concentrations in water from the unconfined aquifer change as water flows to the center of the closed basin (fig. 11), and many samples had dissolvedsolids concentrations larger than $500 \mathrm{mg} / \mathrm{L}$. Dissolved-solids concentrations at the center of the closed basin exceeded $30,000 \mathrm{mg} / \mathrm{L}$ in three samples. The large dissolved-solids concentrations primarily are the result of evapotranspiration (evaporation plus transpiration) from the shallow unconfined aquifer, because water levels in the unconfined aquifer are only 2 or $3 \mathrm{ft}$ below land surface at many locations in the closed basin. As a result, evapotranspiration can remove water from the unconfined aquifer. Dissolved-solids concentrations increase with evapotranspiration because the ions become more concentrated as water leaves the system, causing the remaining water to have more dissolved solids per unit volume of water. Thus, evapotranspiration can be a significant factor affecting dissolved-solids concentrations. Concentrations in shallow ground water also can be increased through use and reuse of the water for irrigation.

The dissolved-solids concentrations in the unconfined aquifer may be affected by dissolution of minerals along the flow path, evapotranspiration, or recharge from irrigation return flow. Water in the unconfined aquifer (sites 23 and 26 ) has a substantially larger concentration of dissolved solids than water from the springs or downgradient wells that tap the confined aquifer (figs. 6 and 7 ). Dissolved-solids concentrations in water from the springs also are in the same range as they are in the confined aquifer downgradient. Therefore, based on the data available, McIntire Spring and Dexter Warm Spring seem to be receiving water primarily from the confined aquifer and not from the unconfined aquifer. However, minor contributions from the unconfined aquifer cannot be ruled out without additional information.

Water-quality data are available for 10 springs in the New Mexico part of the study area. These springs are along or near the Rio Grande. Because of the lack of ground-water information in the area, the source of water issuing from the springs cannot be verified. Selected water-quality characteristics of these springs are listed in table 3 .

In the Conejos River subbasin, water from upgradient wells completed in the confined aquifer has a dissolved-solids concentration ranging from 110 to $118 \mathrm{mg} / \mathrm{L}$. Water from downgradient wells completed in the confined aquifer has larger dissolved-solids concentrations (larger than $200 \mathrm{mg} / \mathrm{L}$ at sites 32 and E, fig. 6) than water from upgradient wells completed in the same aquifer. The increase in dissolved solids can represent the natural increase in dissolved solids from dissolution as water flows downgradient. Downgradient in the unconfined aquifer at site 26 , the concentration of dissolved solids is larger than at the other downgradient sites (figs. 6 and 7). 


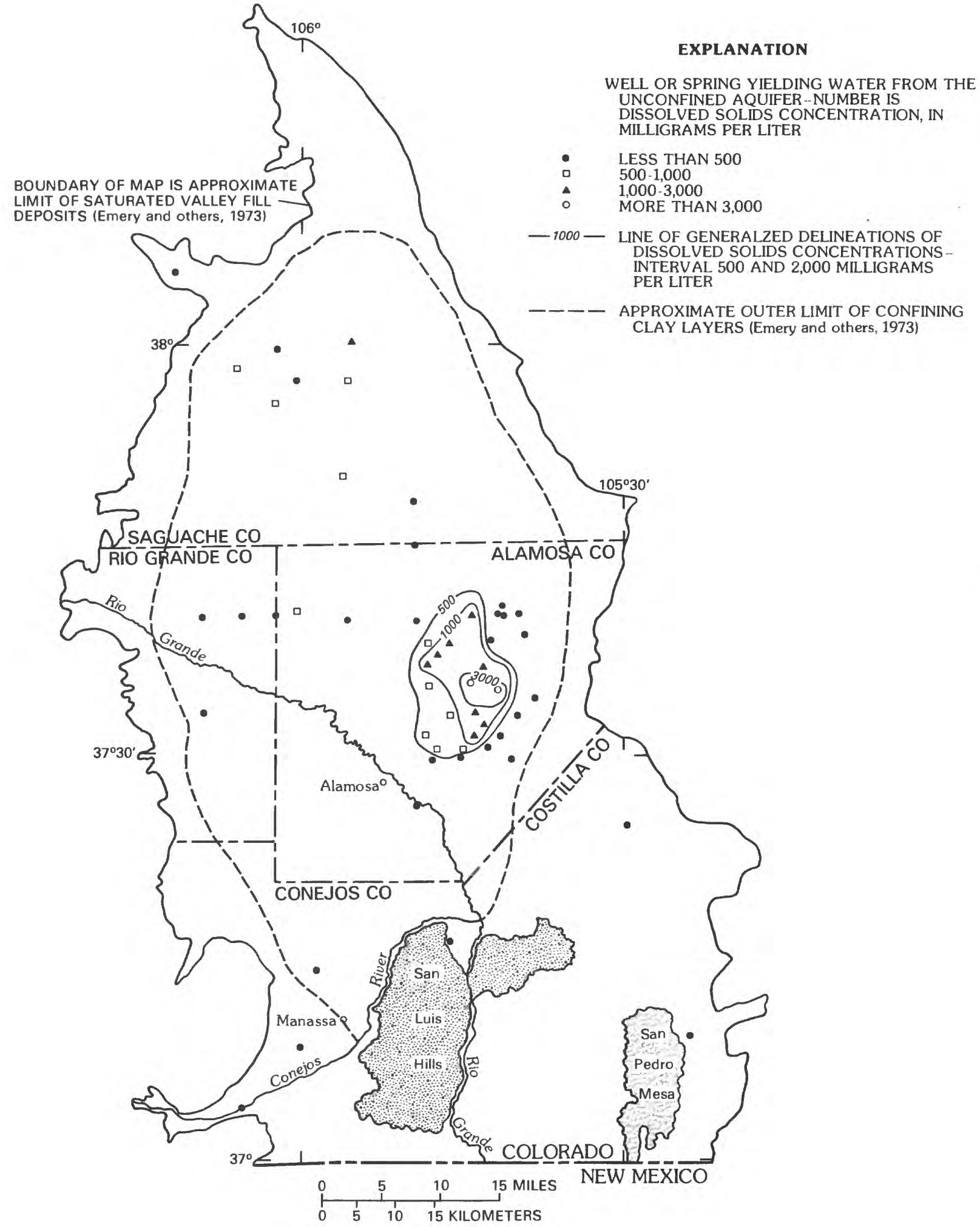

Figure 11.--Areal distribution of dissolved-solids concentrations in the unconfined aquifer (less than 100 feet deep) in the Colorado part of the San Luis Valley. 
Table 3.--Selected water-quality characteristics of springs in the New Mexico part of the San Luis basin

[mg/L, milligrams per liter]

\begin{tabular}{cclc}
\hline $\begin{array}{c}\text { Site } \\
\text { observation } \\
\text { number } \\
(\mathrm{p} 1.1)\end{array}$ & $\begin{array}{c}\text { Date of } \\
\text { sample }\end{array}$ & $\begin{array}{c}\text { Water type } \\
\text { (anion is } \\
\text { bicarbonate) }\end{array}$ & $\begin{array}{c}\text { Dissolved solids } \\
\text { (mg/L) }\end{array}$ \\
\hline 1 & $03-08-83$ & Sodium & 270 \\
2 & $11-17-81$ & Calcium & 370 \\
3 & $07-23-76$ & None dominant & 260 \\
5 & $07-22-76$ & Sodium & 560 \\
6 & $08-19-82$ & Calcium & 150 \\
7 & $08-19-82$ & None dominant & 150 \\
8 & $08-20-82$ & None dominant & 160 \\
9 & $09-06-79$ & None dominant & 260 \\
10 & $03-09-66$ & Calcium & 160 \\
12 & $08-13-80$ & Calcium & \\
\hline
\end{tabular}

\section{Water Temperature and Fluoride Concentrations}

Ground-water temperature and fluoride concentrations commonly increase with depth and in relation to volcanic or geothermal activity. Measurement of water temperature and analyses of fluoride concentrations can help characterize an aquifer. Therefore, because lava flows are present in strata of the San Luis basin, the results of chemical analyses of ground-water samples were evaluated to determine if volcanic or geothermal sources affect the quality of water in the basin aquifers.

The quality of water in selected volcanic environments was documented by White and others (1963) who reported that water temperatures in volcanic areas generally were warmer than $50{ }^{\circ} \mathrm{C}$; ground water in the San Luis basin rarely is warmer than $25{ }^{\circ} \mathrm{C}$. Therefore, ground-water temperatures in the San Luis basin probably are the result of the normal thermal gradient with depth and not the result of volcanic activity.

The temperature of water from wells in the Conejos River subbasin is about $13{ }^{\circ} \mathrm{C}$. Temperatures of water from the downgradient springs and from wells in the confined aquifer range from 16 to $24^{\circ} \mathrm{C}$ (fig. 7). Based on the temperature information, the source of water for the upgradient sites is the unconfined aquifer, while the source for the downgradient sites is the confined aquifer. The exception downgradient is at site 26, where the well is completed in the unconfined aquifer (figs. 6 and 7 ).

Fluoride concentrations may be larger in water that is affected by volcanism (Hem, 1978). Fluoride concentrations north of the Rio Grande in the closed basin have been reported as exceeding drinking-water standards (Emery and others, 1973; Huntley, 1976). However, large concentrations of fluoride were not found in ground water near the San Luis Hills where volcanic activity 
occurred. The ratio of fluoride to chloride commonly is useful for indicating that a disproportionate quantity of fluoride occurs in water from rocks of volcanic origin. However, comparison of the ratios of fluoride to chloride did not indicate a pattern. Therefore, fluoride concentrations in the San Luis basin probably have not been affected by volcanism.

\section{Tritium Concentrations}

Radiochemical dating of ground water by tritium analysis was used to help evaluate whether or not McIntire Spring and Dexter Warm Spring in the Conejos River subbasin yield (1) a mixture of water from the confined and unconfined aquifers, or (2) water solely from the confined aquifer.

Tritium occurs naturally in the atmosphere in very small quantities; one tritium atom occurs naturally for every $10^{18}$ atoms of hydrogen. Tritium also is radioactive and has a half-life of 12.3 years. Atmospheric thermonuclear testing began in 1952 and continued until 1969. These tests resulted in the introduction of bomb-made tritium into the atmosphere. Atmospheric-tritium concentrations changed from pre-1952 levels of 5 to 10 tritium units, to post1952 levels of $100^{\prime} \mathrm{s}$ or $1,000^{\prime} \mathrm{s}$ of tritium units. Tritium occurs naturally in precipitation, some of which enters the ground-water system as recharge.

Therefore, recharge from precipitation prior to 1952 likely would have concentrations of less than 10 tritium units; precipitation that entered the ground after 1952 likely would have larger concentrations of tritium.

McIntire Spring and Dexter Warm Spring were sampled for tritium concentrations. Very small concentrations of tritium would imply that the springs yield water that entered the aquifers prior to 1952. Large tritium concentrations would imply that the springs yield water that entered the aquifers after 1952. Large tritium concentrations in the spring water could indicate that the unconfined aquifer, irrigation-return flow, local recharge, or any combination of the three is the source of water to the springs.

Results of the tritium analyses indicated that water from McIntire Spring contained 5.75 tritium units and that water from Dexter Warm Spring contained 7.66 tritium units. These small concentrations of tritium indicate that the springs are being supplied by pre-1952 water. Therefore, the results of the tritium analyses also support the conclusion that McIntire Spring yields water from the confined aquifer. The tritium analyses are not, however, conclusive proof of this conclusion because of the unknown length of the ground-waterflow path.

The mechanism by which water from the confined aquifer discharges upward to the springs is unknown. A geologic section of the area (fig. 12, modified from an unpublished map from the Colorado Geological Survey, Department of Natural Resources, Office of the State Engineer, 1978) shows a geologic feature that may account for the upward flow-the Manassa fault. This fault or attendant faults may provide a conduit for upward flow of water from the deeper confined lava-gravel complex to McIntire Spring. The upward discharge also could be explained if the confining clay is not present near the San Luis Hills. If the confined and unconfined aquifers are in direct contact, ground water could flow upward and discharge to the springs. 


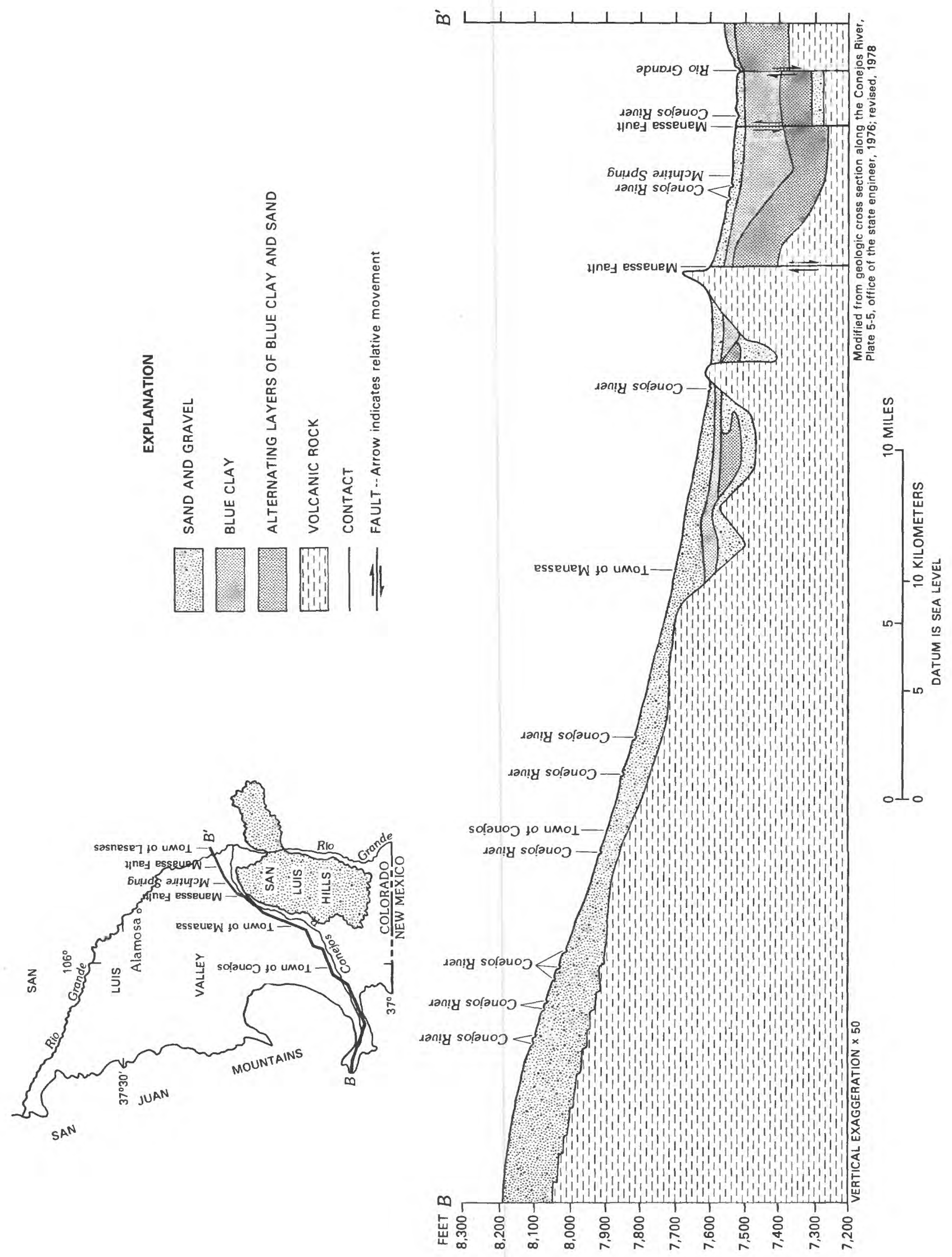

Figure 12.--Diagrammatic geologic section along the Conejos River. 
Chemical data, ground-water flow direction, and geologic structure indicate that the confined aquifer is the source of water for McIntire Spring. However, this finding is not conclusive because it is based on only a few samples from McIntire Spring, Dexter Warm Spring, and the nearby wells. Additional sampling and analyses are needed for verification of the source of water for McIntire Spring. Other springs in the area may have different sources of water.

\section{FUTURE GROUND-WATER INFORMATION NEEDS}

Improved understanding of ground-water resources in the San Luis basin depend on development of an expanded data base and establishment of a monitoring program. Much of this effort could accomplished through expanded data collection at established sites. However, interagency sharing of data and some new test drilling, installation of piezometers, and geophysical investigations would greatly enhance the effort.

About 15,000 wells have been completed in the San Luis basin. A data base consisting of an inventory of these wells could be compiled by combining information from local, State, and Federal data bases. At a minimum, the information for each well should include location, depth, type (municipal, domestic, irrigation, and so forth), and yield.

Representative wells from the inventory could be selected to refine the current geochemical assessment of the basin. These wells could be selected for intensive monitoring along typical ground-water-flow lines. Data needed for each of these wells include: (1) Well depth, (2) zone of completion, (3) method of completion, (4) well logs, (5) mineralogy of strata penetrated, (6) original equilibrated depth to water, (7) yield and results of pumping tests, and (8) original equilibrated water chemistry (major cations/anions and selected trace elements and environmental isotopes). Quality-assurance standards also are needed to ensure that data from the selected wells are compatible.

An initial 1-year monitoring program could be established to address specific questions. The program could include collection of the following data from selected sites:

1. Quarterly measurements of depth to water in wells.

2. Continuous recording of depth to water in wells adjacent to springs.

3. Quarterly sampling of wells for chemical analyses of major cations/anions and selected trace elements.

4. Sampling of wells in the closed basin for analysis of tritium.

5. Quarterly measurements of spring discharge.

6. Sampling of all springs at least once, for the same chemical analyses as for wells, including tritium; quarterly sampling and analysis of water from springs of special interest.

7. Quarterly streamflow gain or loss measurements and sampling for chemical analysis of the Rio Grande and Conejos River.

Evaluation of the 1-year monitoring program would indicate whether activities at some sites could be discontinued, changed in type or scheduling of data collection, or continued on a long-term basis. 
Data are limited in parts of the basin, especially ouside the closed basin area in Colorado, in the Conejos River subbasin in Colorado, and in the a rea south of the San Luis Hills in New Mexico. In these areas, additional test drilling and installation of piezometers and monitoring wells would aid definition of ground-water flow paths.

Finally, the geologic faults in the basin need to be located more accurately using geophysical methods. Data on fault locations, combined with streamflow, spring-discharge, and water-quality data, could help resolve questions about the effect of the faults on the hydraulic connection between aquifers and the discharge of springs.

Economic demands on the water resources have produced many studies in the Colorado part of the San Luis basin. The same economic interests do not seem to be present in New Mexico. However, monitoring of ground water in the area south of the San Luis Hills would help define the hydraulic continuity or discontinuity of that area with the ground-water system in the Conejos River subbasin. Information from such a study would be valuable to water users along the Conejos River and the Rio Grande. Identification of the source of spring water and ground-water inflow to the Rio Grande in New Mexico would be useful information to water managers of the Rio Grande throughout New Mexico.

\section{SUMMARY AND CONCLUSIONS}

The San Luis basin in southern Colorado and northern New Mexico is bounded primarily by the Culebra Range and Sangre de Cristo Mountains to the east and by the Cochetopa Hills and San Juan Mountains to the west. The southern boundary is arbitrarily placed about 15 miles south of the ColoradoNew Mexico border. The basin has been subdivided into five physiographic provinces--the Alamosa Basin, San Luis Hills, Taos Plateau, Costilla Plains, and Culebra Reentrant.

The basin area is underlain by a surficial (less than 100 feet thick) unconfined aquifer and, in turn, by a confining bed and a deeper confined aquifer. The aquifers are recharged around the edges of the basin. Water in the unconfined aquifer moves toward a topographically closed basin north of Alamosa and is discharged primarily by evapotranspiration. There is no ground-water or surface-water flow out of the closed basin. Water in the confined aquifer (confined by an extensive clay layer) moves toward the closed basin and the principal streams and discharges (1) upward along faults to springs, (2) upward by leakage to the unconfined aquifer in areas where the clay layer is absent, and (3) to the Rio Grande and Conejos River.

Data on the chemical quality of water from wells and springs in the San Luis basin were retrieved from the WATSTORE file for evaluation in this study. The data were separated into results of chemical analyses having an ionic balance within 10 percent and analyses for specific constituents deemed necessary for this study. The data were further separated into results from the unconfined and confined aquifers. The final data set for evaluation included results of analyses from 99 wells and 19 springs. 
The evaluation of water-quality data showed that ground water at the perimeter of the San Luis basin is primarily a calcium bicarbonate type, which is typical in recharge areas. Ground water near the center of the basin is primarily a sodium bicarbonate type, which is typical of ground water in downgradient areas. The change in principal cation from calcium to sodium indicates chemical evolution of the water along the ground-water flow path and supports previously developed concepts of ground-water movement in the basin.

The exchange of calcium for sodium along the flow path also is assumed to occur in the Conejos River subbasin. Upgradient wells yield calcium bicarbonate type water, whereas downgradient wells yield sodium bicarbonate type water. However, an exception to this relation is found at McIntire Spring, which yields calcium bicarbonate type water from a downgradient location. The source of water discharging from the spring may be the confined aquifer, with hydraulic connection along the Manassa fault.

Previously developed concepts of ground-water movement in the San Luis basin also are supported by areal changes in dissolved-solids concentrations. The concentration of dissolved solids in water from both the unconfined and confined aquifers increases downgradient. The increase is dramatic in the closed basin, ranging from less than $500 \mathrm{mg} / \mathrm{L}$ to more $30,000 \mathrm{mg} / \mathrm{L}$. In this area, the normal increase in concentration by dissolution of minerals along the flow path is exceeded by the increase due to evapotranspiration from the shallow water table.

Improved understanding and management of ground-water resources in the San Luis basin depend on development of an expanded data base on wells. In addition, this understanding and management depend on the establishment of a comprehensive program for monitoring water levels and water quality.

\section{REFERENCES CITED}

Burroughs, R.L., 1981, A summary of the geology of the San Luis Basin, Colorado-New Mexico, with emphasis on the geothermal potential for the Monte Vista Graben: Denver, Colorado Geological Survey Special Publication $17,30 \mathrm{p}$.

Chebotarev, I.I., 1955, Metamorphism of natural waters in the crust of weathering: Geochimica et Cosmochimica Acta, v. 8, no. 1, p. 22-48, p. 137-170; p. 198-212.

Colorado Geological Survey, Department of Natural Resources, Office of the State Engineer, 1978, Geologic cross section along the Conejos River in south-central Colorado: Denver, Unpublished map, no scale.

Crouch, T.M., 1985, Potentiometric surface, 1980, and water-level changes, 1969-1980, in the unconfined valley-fill aquifers of the San Luis basin, Colorado and New Mexico: U.S. Geological Survey Hydrologic Investigations Atlas HA-683, scale $1: 250,000,2$ sheets.

Edelmann, P.F., and Buckles, D.R., 1984, Quality of ground water in agricultural areas of the San Luis Valley, south-central Colorado: U.S. Geological Survey Water-Resources Investigations Report 83-4281, 37 p.

Emery, P.A., Boettcher, A.J., Snipes, R.J., and McIntyre, H.J., Jr., 1971, Hydrology of the San Luis Valley, south-central Colorado: U.S. Geological Survey Hydrologic Investigation Atlas HA-381, scale 1:250,000. 
Emery, P.A., Patten, E.P., Jr., and Moore, J.E., 1975, Analog model study of the hydrology of the San Luis Valley, south-central Colorado: Denver, Colorado Water Conservation Board, Water Resources Circular 29, 21 p.

Emery, P.A., Snipes, R.J., and Dumeyer, J.M., 1972, Hydrologic data for the San Luis Valley, Colorado: Denver, Colorado Water Conservation Board, Basic-Data Release 22, 146 p.

Emery, P.A., Snipes, R.J., Dumeyer, J.M., and Klein, J.M., 1973, Water in the San Luis Valley, south-central Colorado: Denver, Colorado Water Conservation Board, Colorado Water Resources Circular 18, 26 p.

ENMAP Corporation, 1981, Guide to Colorado's weather and climate: Boulder, Colo., $1 \mathrm{p}$.

Hem, J.D., 1978, Study and interpretation of the chemical characteristics of natural water (2d ed): U.S. Geological Survey Water Supply Paper 1473, rev., $363 \mathrm{p}$.

Huntley, David, 1976, Ground-water recharge to the aquifers of northern San Luis Valley, Colorado; summary: Geological Society of America Bulletin, August 1979, v. 90, no. 8, pl. 1, p. 707-709.

Hutchison, N.E., compiler, 1975, National water data storage and retrieval system of the U.S. Geological Survey--WATSTORE User's Guide: U.S. Geological Survey Open-File Report 75-426, 791 p.

Siebenthal, C.E., 1910, Geology and water resources of the San Luis Valley, Colorado: U.S. Geological Survey Water-Supply Paper 240, 9 p.

U.S. Environmental Protection Agency, 1986, Quality criteria for water 1986: U.S. Environmental Protection Agency 440/5-86-001, $1 \mathrm{v}$.

Upson, J.E., 1939, Physiographic subdivisions of the San Luis Valley, southern Colorado: Journal of Geology, v. 47, no. 7, p. 721-736.

White, D.E., Hem, J.D., and Waring, G.A., 1963, Chapter F., Chemical composition of subsurface waters, in Fleischer, M., Data of geochemistry, (6th ed.): U.S. Geological Survey Professional Paper 440-F, 45 p.

Winograd, I.J., 1959, Ground-water conditions and geology of Sunshine Valley and western Taos County, New Mexico: Santa Fe, New Mexico State Engineers Office, Technical Report no. 12, p. 70. 
SUPPLEMENTAL WATER-QUALITY DATA 
Table 4.--Water-quality information from selected wells and springs in the San Luis basin in Colorado and New Mexico

[mo/d/yr, month/day/year; gal/min, gallons per minute; ${ }^{\circ} \mathrm{C}$, degree Celsius; $\mu \mathrm{S} / \mathrm{cm}$, microsiemens per centimeter at $25{ }^{\circ} \mathrm{C} ; \mathrm{mg} / \mathrm{L}$, milligrams per liter; $\mu \mathrm{g} / \mathrm{L}$, micrograms per liter; SP, spring; GW, ground water; ND, not detected; TU, tritium unit; --, no data]

\begin{tabular}{|c|c|c|c|c|c|c|c|c|c|c|c|}
\hline $\begin{array}{l}\text { Site } \\
\text { obser- } \\
\text { vation } \\
\text { number }\end{array}$ & Latitude & Longitude & $\begin{array}{l}\text { Se- } \\
\text { quence } \\
\text { num- } \\
\text { ber }\end{array}$ & $\begin{array}{c}\text { Local } \\
\text { identifier }\end{array}$ & $\begin{array}{l}\text { Sample } \\
\text { source }\end{array}$ & $\begin{array}{l}\text { Date of } \\
\text { sample } \\
\text { (mo/d/yr) }\end{array}$ & $\begin{array}{c}\text { Depth } \\
\text { to } \\
\text { water } \\
\text { (feet) }\end{array}$ & $\begin{array}{c}\text { Flow } \\
\text { rate } \\
(\text { gal/min })\end{array}$ & $\begin{array}{l}\text { Temper- } \\
\text { ature } \\
\left({ }^{\circ} \mathrm{C}\right)\end{array}$ & $\begin{array}{c}\text { Spe- } \\
\text { cific } \\
\text { con- } \\
\text { duct- } \\
\text { ance, } \\
\text { field } \\
(\mu \mathrm{S} / \mathrm{cm})\end{array}$ & $\begin{array}{c}\text { Spe- } \\
\text { cific } \\
\text { con- } \\
\text { duct- } \\
\text { ance, } \\
\text { labor- } \\
\text { atory } \\
(\mu \mathrm{S} / \mathrm{cm})\end{array}$ \\
\hline $\begin{array}{l}1 \\
2\end{array}$ & $\begin{array}{l}36^{\circ} 10^{\prime} 54^{\prime \prime} \\
36^{\circ} 13^{\prime} 04^{\prime \prime}\end{array}$ & $\begin{array}{l}105^{\circ} 50^{\prime} 47^{\prime \prime} \\
105^{\circ} 51^{\prime} 25^{\prime \prime}\end{array}$ & $\begin{array}{l}01 \\
01\end{array}$ & $\begin{array}{l}\text { NA02301035 } \\
\text { NA02301022 }\end{array}$ & $\begin{array}{l}\text { SP } \\
\text { SP }\end{array}$ & $\begin{array}{l}03-08-83 \\
11-17-81\end{array}$ & $\ddot{--}$ & -- & $\begin{array}{l}8.0 \\
7.0\end{array}$ & $\begin{array}{l}410 \\
550\end{array}$ & $\begin{array}{l}455 \\
602\end{array}$ \\
\hline 3 & $36^{\circ} 19^{\prime} 56^{\prime \prime}$ & $105^{\circ} 44^{\prime} 22^{\prime \prime}$ & 01 & $\begin{array}{l}\text { Gijosa Grant } \\
\text { Spring }\end{array}$ & $\mathbf{S P}$ & $07-23-76$ & -- & -- & 17.0 & 380 & -- \\
\hline $\begin{array}{l}4 \\
5\end{array}$ & $\begin{array}{l}36^{\circ} 24^{\prime} 36^{\prime \prime} \\
36^{\circ} 31^{\prime} 51^{\prime \prime}\end{array}$ & $\begin{array}{l}105^{\circ} 34^{\prime} 20^{\prime \prime} \\
105^{\circ} 42^{\prime} 42^{\prime \prime}\end{array}$ & $\begin{array}{l}01 \\
01\end{array}$ & $\begin{array}{l}\text { NA02501308DCD1 } \\
\text { NA02701231CBB }\end{array}$ & $\begin{array}{l}\text { GW } \\
\text { SP }\end{array}$ & $\begin{array}{l}09-06-79 \\
07-22-76\end{array}$ & $\begin{array}{l}204 \\
--\end{array}$ & 170 & $\begin{array}{l}12.5 \\
37.0\end{array}$ & $\begin{array}{l}490 \\
760\end{array}$ & $\overline{--}$ \\
\hline $\begin{array}{l}6 \\
7\end{array}$ & $\begin{array}{l}36^{\circ} 32^{\prime} 15^{\prime \prime} \\
36^{\circ} 40^{\prime} 42^{\prime \prime}\end{array}$ & $\begin{array}{l}105^{\circ} 42^{\prime} 23^{\prime \prime} \\
105^{\circ} 39^{\prime} 39^{\prime \prime}\end{array}$ & $\begin{array}{l}01 \\
01\end{array}$ & $\begin{array}{l}\text { NA02701231 } \\
\text { NA02801209 }\end{array}$ & $\begin{array}{l}\text { SP } \\
\text { SP }\end{array}$ & $\begin{array}{l}08-19-82 \\
08-19-82\end{array}$ & -- & -- & $\begin{array}{l}15.0 \\
17.0\end{array}$ & $\begin{array}{l}210 \\
210\end{array}$ & $\begin{array}{l}235 \\
234\end{array}$ \\
\hline 8 & $36^{\circ} 40^{\prime} 47^{\prime \prime}$ & $105^{\circ} 41^{\prime} 11^{\prime \prime}$ & 01 & $\begin{array}{l}\text { Big Arsenic } \\
\text { Springs }\end{array}$ & SP & $08-20-82$ & -- & -- & 18.0 & 220 & 234 \\
\hline $\begin{array}{r}9 \\
10\end{array}$ & $\begin{array}{l}36^{\circ} 41^{\prime} 05^{\prime \prime} \\
36^{\circ} 41^{\prime} 30^{\prime \prime}\end{array}$ & $\begin{array}{l}105^{\circ} 41^{\prime} 05^{\prime \prime} \\
105^{\circ} 37^{\prime} \cdot 18^{\prime \prime}\end{array}$ & $\begin{array}{l}01 \\
01\end{array}$ & $\begin{array}{l}\text { NAO2801217ABB } \\
\text { NA02801201BCC }\end{array}$ & $\begin{array}{l}\text { SP } \\
\text { SP }\end{array}$ & $\begin{array}{l}09-06-79 \\
03-09-66\end{array}$ & -- & -- & $\begin{array}{r}14.5 \\
8.5\end{array}$ & $\begin{array}{l}220 \\
412\end{array}$ & -- \\
\hline $\begin{array}{l}11 \\
12 \\
13 \\
14 \\
15\end{array}$ & $\begin{array}{l}36^{\circ} 58^{\prime} 30^{\prime \prime} \\
36^{\circ} 58^{\prime} 59^{\prime \prime} \\
37^{\circ} 01^{\prime} 15^{\prime \prime} \\
37^{\circ} 02^{\prime} 57^{\prime \prime} \\
37^{\circ} 03^{\prime} 24^{\prime \prime}\end{array}$ & $\begin{array}{l}105^{\circ} 46^{\prime} 47^{\prime \prime} \\
106^{\circ} 12^{\prime} 28^{\prime \prime} \\
105^{\circ} 37^{\prime} 05^{\prime \prime} \\
105^{\circ} 55^{\prime} 39^{\prime \prime} \\
105^{\circ} 56^{\prime} 12^{\prime \prime}\end{array}$ & $\begin{array}{l}01 \\
01 \\
01 \\
01 \\
01\end{array}$ & $\begin{array}{l}\text { NA03201128 } \\
\text { NA03200728ABC } \\
\text { CB00107425AAA } \\
\text { NA03300935DBB } \\
\text { NA03300936DBB }\end{array}$ & $\begin{array}{l}\text { GW } \\
\text { SP } \\
\text { GW } \\
\text { GW } \\
\text { GW }\end{array}$ & $\begin{array}{l}06-01-81 \\
08-13-80 \\
06-26-68 \\
06-04-82 \\
06-04-82\end{array}$ & $\begin{array}{l}355 \\
-- \\
284 \\
225 \\
223\end{array}$ & $\begin{array}{l}-- \\
-- \\
-- \\
--\end{array}$ & $\begin{array}{r}12.0 \\
8.5 \\
11.0 \\
11.5 \\
10.5\end{array}$ & $\begin{array}{l}155 \\
240 \\
203 \\
190 \\
202\end{array}$ & $\begin{array}{r}165 \\
-- \\
-- \\
195 \\
209\end{array}$ \\
\hline $\begin{array}{l}16 \\
17 \\
18 \\
19 \\
20\end{array}$ & $\begin{array}{l}37^{\circ} 03^{\prime} 24^{\prime \prime} \\
37^{\circ} 03^{\prime} 26^{\prime \prime} \\
37^{\circ} 03^{\prime} 35^{\prime \prime} \\
37^{\circ} 08^{\prime} 12^{\prime \prime} \\
37^{\circ} 09^{\prime} 16^{\prime \prime}\end{array}$ & $\begin{array}{l}105^{\circ} 57^{\prime} 18^{\prime \prime} \\
105^{\circ} 59^{\prime} 43^{\prime \prime} \\
106^{\circ} 05^{\prime} 29^{\prime \prime} \\
105^{\circ} 59^{\prime} 48^{\prime \prime} \\
105^{\circ} 23^{\prime} 31^{\prime \prime}\end{array}$ & $\begin{array}{l}01 \\
02 \\
01 \\
01 \\
01\end{array}$ & $\begin{array}{l}\text { NA03300935DBB } \\
\text { NA03300933CAB2 } \\
\text { NA03300834BCB } \\
\text { NA03300904BBA } \\
\text { CB00207212ADC }\end{array}$ & $\begin{array}{l}\text { GW } \\
\text { GW } \\
\text { GW } \\
\text { GW } \\
\text { GW }\end{array}$ & $\begin{array}{l}06-04-82 \\
06-04-82 \\
08-29-79 \\
09-09-68 \\
09-10-68\end{array}$ & $\begin{array}{r}225 \\
235 \\
90 \\
16 \\
13\end{array}$ & $\begin{array}{l}-- \\
-- \\
3.0 \\
--\end{array}$ & $\begin{array}{l}10.5 \\
10.5 \\
11.0 \\
13.0 \\
11.0\end{array}$ & $\begin{array}{r}-164 \\
247 \\
230 \\
232 \\
187\end{array}$ & $\begin{array}{r}169 \\
261 \\
-- \\
-- \\
--\end{array}$ \\
\hline $\begin{array}{l}21 \\
22 \\
23 \\
24 \\
25\end{array}$ & $\begin{array}{l}37^{\circ} 10^{\prime} 06^{\prime \prime} \\
37^{\circ} 11^{\prime} 45^{\prime \prime} \\
37^{\circ} 13^{\prime} 34^{\prime \prime} \\
37^{\circ} 13^{\prime} 32^{\prime \prime} \\
37^{\circ} 14^{\prime} 25^{\prime \prime}\end{array}$ & $\begin{array}{l}105^{\circ} 56^{\prime} 07^{\prime \prime} \\
105^{\circ} 52^{\prime} 30^{\prime \prime} \\
105^{\circ} 58^{\prime} 20^{\prime \prime} \\
105^{\circ} 56^{\prime} 45^{\prime \prime} \\
105^{\circ} 32^{\prime} 04^{\prime \prime}\end{array}$ & $\begin{array}{l}01 \\
01 \\
01 \\
01 \\
01\end{array}$ & $\begin{array}{l}\text { NA03400924DCC } \\
\text { NA03401016AAA } \\
\text { NA03500934DCC } \\
\text { NA03500936CCC } \\
\text { CB00307311BDB }\end{array}$ & $\begin{array}{l}\text { GW } \\
\text { GW } \\
\text { GW } \\
\text { GW } \\
\text { GW }\end{array}$ & $\begin{array}{l}06-03-82 \\
06-02-82 \\
09-10-68 \\
08-08-68 \\
05-14-68\end{array}$ & $\begin{array}{r}806 \\
575 \\
16 \\
695 \\
205\end{array}$ & $\begin{array}{l}-- \\
-- \\
-- \\
-- \\
--\end{array}$ & $\begin{array}{l}13.0 \\
12.5 \\
13.0 \\
14.0 \\
10.0\end{array}$ & $\begin{array}{l}143 \\
148 \\
378 \\
147 \\
378\end{array}$ & $\begin{array}{r}148 \\
171 \\
-- \\
-- \\
--\end{array}$ \\
\hline $\begin{array}{l}26 \\
27 \\
28 \\
29 \\
30\end{array}$ & $\begin{array}{l}37^{\circ} 15^{\prime} 58^{\prime \prime} \\
37^{\circ} 16^{\prime} 48^{\prime \prime} \\
37^{\circ} 17^{\prime} 30^{\prime \prime} \\
37^{\circ} 17^{\prime} 58^{\prime \prime} \\
37^{\circ} 17^{\prime} 58^{\prime \prime}\end{array}$ & $\begin{array}{l}105^{\circ} 45^{\prime} 57^{\prime \prime} \\
105^{\circ} 48^{\prime} 34^{\prime \prime} \\
105^{\circ} 33^{\prime} 09^{\prime \prime} \\
105^{\circ} 39^{\prime} 20^{\prime \prime} \\
105^{\circ} 39^{\prime} 20^{\prime \prime}\end{array}$ & $\begin{array}{l}01 \\
00 \\
01 \\
01 \\
01\end{array}$ & $\begin{array}{l}\text { NA03501121AAD } \\
\text { McIntire Spring } \\
\text { CC03207304CAD } \\
\text { CC03207404AAA } \\
\text { CC03207404AAA }\end{array}$ & $\begin{array}{l}\text { GW } \\
\text { SP } \\
\text { GW } \\
\text { GW } \\
\text { GW }\end{array}$ & $\begin{array}{l}09-09-68 \\
04-19-76 \\
06-07-68 \\
08-20-68 \\
07-23-80\end{array}$ & $\begin{array}{r}9 \\
-- \\
384 \\
392 \\
392\end{array}$ & $\begin{array}{l}-- \\
5.0 \\
-- \\
--\end{array}$ & $\begin{array}{l}13.0 \\
14.0 \\
15.0 \\
16.0 \\
18.5\end{array}$ & $\begin{array}{l}653 \\
265 \\
225 \\
448 \\
415\end{array}$ & $\begin{array}{l}-- \\
-- \\
-- \\
-- \\
--\end{array}$ \\
\hline 31 & $37^{\circ} 17^{\prime} 41^{\prime \prime}$ & $105^{\circ} 47^{\prime} 05^{\prime \prime}$ & 00 & $\begin{array}{l}\text { Dexter Warm } \\
\text { Spring }\end{array}$ & SP & $04-19-76$ & -- & 50 & 20.0 & 340 & -- \\
\hline $\begin{array}{l}32 \\
33 \\
34 \\
35\end{array}$ & $\begin{array}{l}37^{\circ} 18^{\prime} 45^{\prime \prime} \\
37^{\circ} 23^{\prime} 26^{\prime \prime} \\
37^{\circ} 23^{\prime} 19^{\prime \prime} \\
37^{\circ} 23^{\prime} 45^{\prime \prime}\end{array}$ & $\begin{array}{l}105^{\circ} 45^{\prime} 50^{\prime \prime} \\
105^{\circ} 36^{\prime} 38^{\prime \prime} \\
105^{\circ} 25^{\prime} 05^{\prime \prime} \\
105^{\circ} 36^{\prime} 37^{\prime \prime}\end{array}$ & $\begin{array}{l}01 \\
01 \\
01 \\
01\end{array}$ & $\begin{array}{l}\text { NA03601134CCC } \\
\text { CC03007436BCD } \\
\text { CC03007234DCD } \\
\text { SC03007436BDD }\end{array}$ & $\begin{array}{l}\text { GW } \\
\text { GW } \\
\text { GW } \\
\text { GW }\end{array}$ & $\begin{array}{l}08-19-68 \\
06-18-68 \\
06-26-68 \\
07-22-80\end{array}$ & $\begin{array}{l}318 \\
340 \\
154 \\
340\end{array}$ & $\begin{array}{l}-- \\
-- \\
-- \\
--\end{array}$ & $\begin{array}{l}24.0 \\
13.0 \\
10.0 \\
13.0\end{array}$ & $\begin{array}{l}285 \\
372 \\
239 \\
360\end{array}$ & $\begin{array}{l}-- \\
-- \\
--\end{array}$ \\
\hline $\begin{array}{l}36 \\
37 \\
38 \\
39 \\
40\end{array}$ & $\begin{array}{l}37^{\circ} 24^{\prime} 05^{\prime \prime} \\
37^{\circ} 24^{\prime} 43^{\prime \prime} \\
37^{\circ} 24^{\prime} 17^{\prime \prime} \\
37^{\circ} 25^{\prime} 00^{\prime \prime} \\
37^{\circ} 25^{\prime} 50^{\prime \prime}\end{array}$ & $\begin{array}{l}105^{\circ} 54^{\prime} 10^{\prime \prime} \\
105^{\circ} 29^{\prime} 24^{\prime \prime} \\
105^{\circ} 31^{\prime} 26^{\prime \prime} \\
106^{\circ} 00^{\prime} 00^{\prime \prime} \\
105^{\circ} 49^{\prime} 08^{\prime \prime}\end{array}$ & $\begin{array}{l}02 \\
01 \\
01 \\
01 \\
01\end{array}$ & $\begin{array}{l}\text { NA03701032CDC2 } \\
\text { CC03007324DDD } \\
\text { SC03007327ADA } \\
\text { NA03700928CCB2 } \\
\text { NA03701119CCC }\end{array}$ & $\begin{array}{l}\text { GW } \\
\text { GW } \\
\text { GW } \\
\text { GW } \\
\text { GW }\end{array}$ & $\begin{array}{l}05-07-68 \\
09-10-68 \\
07-22-80 \\
07-18-68 \\
09-10-68\end{array}$ & $\begin{array}{r}1,721 \\
9 \\
240 \\
2,640 \\
12\end{array}$ & $\begin{array}{l}-- \\
-- \\
-- \\
--\end{array}$ & $\begin{array}{l}24.0 \\
14.0 \\
10.0 \\
24.0 \\
16.0\end{array}$ & $\begin{array}{l}226 \\
336 \\
350 \\
255 \\
390\end{array}$ & $\begin{array}{l}-- \\
-- \\
-- \\
--\end{array}$ \\
\hline $\begin{array}{l}41 \\
42 \\
43 \\
44 \\
45\end{array}$ & $\begin{array}{l}37^{\circ} 25^{\prime} 50^{\prime \prime} \\
37^{\circ} 27^{\prime} 05^{\prime \prime} \\
37^{\circ} 28^{\prime} 25^{\prime \prime} \\
37^{\circ} 29^{\prime} 16^{\prime \prime} \\
37^{\circ} 29^{\prime} 23^{\prime \prime}\end{array}$ & $\begin{array}{l}105^{\circ} 45^{\prime} 50^{\prime \prime} \\
105^{\circ} 30^{\prime} 28^{\prime \prime} \\
106^{\circ} 04^{\prime} 00^{\prime \prime} \\
105^{\circ} 42^{\prime} 44^{\prime \prime} \\
105^{\circ} 40^{\prime} 25^{\prime \prime}\end{array}$ & $\begin{array}{l}01 \\
01 \\
01 \\
01 \\
01\end{array}$ & $\begin{array}{l}\text { NA03701122CCC1 } \\
\text { CC03007311ADD } \\
\text { NA03700802CDD } \\
\text { NA03701101AAA } \\
\text { NA03801233CCC }\end{array}$ & $\begin{array}{l}\text { GW } \\
\text { GW } \\
\text { GW } \\
\text { GW } \\
\text { GW }\end{array}$ & $\begin{array}{l}08-23-68 \\
06-07-68 \\
07-19-68 \\
08-05-68 \\
08-05-68\end{array}$ & $\begin{array}{r}2,062 \\
310 \\
1,401 \\
11 \\
16\end{array}$ & $\begin{array}{l}-- \\
-- \\
-- \\
--\end{array}$ & $\begin{array}{l}33.0 \\
12.0 \\
19.0 \\
16.0 \\
11.0\end{array}$ & $\begin{array}{l}548 \\
197 \\
174 \\
330 \\
161\end{array}$ & $\begin{array}{l}-- \\
-- \\
-- \\
--\end{array}$ \\
\hline
\end{tabular}


Table 4.--Water-quality information from selected wells and springs in the San Luis basin in Colorado and New Mexico--Continued

\begin{tabular}{|c|c|c|c|c|c|c|c|c|c|c|c|}
\hline $\begin{array}{l}\text { Site } \\
\text { obser- } \\
\text { vation } \\
\text { number }\end{array}$ & Latitude & Longitude & $\begin{array}{l}\text { Se- } \\
\text { quence } \\
\text { num- } \\
\text { ber }\end{array}$ & $\begin{array}{c}\text { Local } \\
\text { identifier }\end{array}$ & $\begin{array}{l}\text { Sample } \\
\text { source }\end{array}$ & $\begin{array}{l}\text { Date of } \\
\text { sample } \\
\text { (mo/d/yr) }\end{array}$ & $\begin{array}{c}\text { Depth } \\
\text { to } \\
\text { water } \\
\text { (feet) }\end{array}$ & $\begin{array}{c}\text { Flow } \\
\text { rate } \\
(\mathrm{gal} / \mathrm{min})\end{array}$ & $\begin{array}{l}\text { Temper- } \\
\text { a ture } \\
\left({ }^{\circ} \mathrm{C}\right)\end{array}$ & $\begin{array}{c}\text { Spe- } \\
\text { cific } \\
\text { con- } \\
\text { duct- } \\
\text { ance, } \\
\text { field } \\
(\mu \mathrm{S} / \mathrm{cm})\end{array}$ & $\begin{array}{c}\text { Spe- } \\
\text { cific } \\
\text { con- } \\
\text { duct- } \\
\text { ance, } \\
\text { labor- } \\
\text { atory } \\
(\mu \mathrm{S} / \mathrm{cm})\end{array}$ \\
\hline $\begin{array}{l}46 \\
47\end{array}$ & $\begin{array}{l}37^{\circ} 29^{\prime} 20^{\prime \prime} \\
37^{\circ} 30^{\prime} 12^{\prime \prime}\end{array}$ & $\begin{array}{l}105^{\circ} 47^{\prime} 56^{\prime \prime} \\
105^{\circ} 47^{\prime} 06^{\prime \prime}\end{array}$ & $\begin{array}{ll}01 & 1 \\
01 & 1\end{array}$ & \multirow{3}{*}{$\begin{array}{l}\text { NA03801132CCD } \\
\text { NA03801129DDD } \\
\text { Splashland Hot } \\
\text { Springs } \\
\text { NA03801134DDA1 } \\
\text { NA03801135BBB }\end{array}$} & $\begin{array}{l}\text { GW } \\
\text { GW }\end{array}$ & $\begin{array}{l}08-05-68 \\
08-09-68\end{array}$ & $\begin{array}{l}13 \\
16\end{array}$ & -- & $\begin{array}{l}11.0 \\
11.0\end{array}$ & $\begin{array}{l}219 \\
894\end{array}$ & -- \\
\hline 48 & $37^{\circ} 29^{\prime} 19^{\prime \prime}$ & $105^{\circ} 51^{\prime} 27^{\prime \prime}$ & 00 & & GW & $08-12-75$ & -- & -- & 40.5 & 365 & -- \\
\hline $\begin{array}{l}49 \\
50\end{array}$ & $\begin{array}{l}37^{\circ} 29^{\prime} 29^{\prime \prime} \\
37^{\circ} 30^{\prime} 07^{\prime \prime}\end{array}$ & $\begin{array}{l}105^{\circ} 44^{\prime} 54^{\prime \prime} \\
105^{\circ} 44^{\prime} 47^{\prime \prime}\end{array}$ & $\begin{array}{ll}01 & 1 \\
01 & 1\end{array}$ & & $\begin{array}{l}\text { GW } \\
\text { GW }\end{array}$ & $\begin{array}{l}07-31-80 \\
08-05-68\end{array}$ & $\begin{array}{l}29.5 \\
22\end{array}$ & -- & $\begin{array}{l}11.0 \\
10.0\end{array}$ & $\begin{array}{l}685 \\
834\end{array}$ & -- \\
\hline $\begin{array}{l}51 \\
52 \\
53 \\
54 \\
55\end{array}$ & $\begin{array}{l}37^{\circ} 30^{\prime} 15^{\prime \prime} \\
37^{\circ} 31^{\prime} 08^{\prime \prime} \\
37^{\circ} 31^{\prime} 05^{\prime \prime} \\
37^{\circ} 31^{\prime} 08^{\prime \prime} \\
37^{\circ} 31^{\prime} 04^{\prime \prime}\end{array}$ & $\begin{array}{l}105^{\circ} 42^{\prime} 36^{\prime \prime} \\
105^{\circ} 41^{\prime} 29^{\prime \prime} \\
105^{\circ} 48^{\prime} 04^{\prime \prime} \\
105^{\circ} 43^{\prime} 44^{\prime \prime} \\
105^{\circ} 40^{\prime} 45^{\prime \prime}\end{array}$ & $\begin{array}{ll}01 & 1 \\
01 & 1 \\
01 & 1 \\
01 & 1 \\
01 & 1\end{array}$ & $\begin{array}{l}\text { NA03801230CCC } \\
\text { NA03801220CCC } \\
\text { NA03801120CCC } \\
\text { NA03801124CCC } \\
\text { NA03801229AAB1 }\end{array}$ & $\begin{array}{l}\text { GW } \\
\text { GW } \\
\text { GW } \\
\text { GW } \\
\text { GW }\end{array}$ & $\begin{array}{l}08-05-68 \\
08-05-68 \\
08-09-68 \\
08-05-68 \\
08-22-78\end{array}$ & $\begin{array}{r}14 \\
17 \\
16 \\
21 \\
100\end{array}$ & $\begin{array}{l}-- \\
-- \\
-- \\
--\end{array}$ & $\begin{array}{l}11.0 \\
10.0 \\
10.0 \\
10.0 \\
20.5\end{array}$ & $\begin{array}{r}132 \\
219 \\
910 \\
1,970 \\
150\end{array}$ & $\begin{array}{l}-- \\
-- \\
-- \\
--\end{array}$ \\
\hline $\begin{array}{l}56 \\
57 \\
58 \\
59 \\
60\end{array}$ & $\begin{array}{l}37^{\circ} 31^{\prime} 10^{\prime \prime} \\
37^{\circ} 32^{\prime} 01^{\prime \prime} \\
37^{\circ} 32^{\prime} 45^{\prime \prime} \\
37^{\circ} 32^{\prime} 42^{\prime \prime} \\
37^{\circ} 32^{\prime} 51^{\prime \prime}\end{array}$ & $\begin{array}{l}105^{\circ} 58^{\prime} 55^{\prime \prime} \\
105^{\circ} 42^{\prime} 44^{\prime \prime} \\
105^{\circ} 39^{\prime} 58^{\prime \prime} \\
105^{\circ} 46^{\prime} 03^{\prime \prime} \\
105^{\circ} 43^{\prime} 43^{\prime \prime}\end{array}$ & $\begin{array}{ll}01 & 1 \\
01 & 1 \\
01 & 1 \\
01 & 1 \\
01 & 1\end{array}$ & $\begin{array}{l}\text { NA03800922CBC } \\
\text { NA03801113DDD } \\
\text { NA03801216BAA } \\
\text { NA03801116AAA } \\
\text { NA03801112CCC }\end{array}$ & $\begin{array}{l}\text { GW } \\
\text { GW } \\
\text { GW } \\
\text { GW } \\
\text { GW }\end{array}$ & $\begin{array}{l}07-18-68 \\
08-07-68 \\
08-07-68 \\
08-09-68 \\
08-07-68\end{array}$ & $\begin{array}{r}1,840 \\
16 \\
18 \\
15 \\
22\end{array}$ & $\begin{array}{l}-- \\
\therefore \\
-- \\
--\end{array}$ & $\begin{array}{l}23.0 \\
12.0 \\
12.0 \\
12.0 \\
11.0\end{array}$ & $\begin{array}{r}266 \\
3,320 \\
112 \\
1,090 \\
3,370\end{array}$ & $\begin{array}{l}-- \\
-- \\
-- \\
--\end{array}$ \\
\hline $\begin{array}{l}61 \\
62 \\
63 \\
64 \\
65\end{array}$ & $\begin{array}{l}37^{\circ} 32^{\prime} 41^{\prime \prime} \\
37^{\circ} 33^{\prime} 57^{\prime \prime} \\
37^{\circ} 33^{\prime} 15^{\prime \prime} \\
37^{\circ} 34^{\prime} 30^{\prime \prime} \\
37^{\circ} 34^{\prime} 33^{\prime \prime}\end{array}$ & $\begin{array}{l}106^{\circ} 08^{\prime} 51^{\prime \prime} \\
105^{\circ} 38^{\prime} 11^{\prime \prime} \\
105^{\circ} 50^{\prime} 45^{\prime \prime} \\
105^{\circ} 41^{\prime} 36^{\prime \prime} \\
105^{\circ} 48^{\prime} 06^{\prime \prime}\end{array}$ & $\begin{array}{ll}01 & 1 \\
01 & 1 \\
01 & 1 \\
01 & 1 \\
01 & 1\end{array}$ & $\begin{array}{l}\text { NA03800818BBB } \\
\text { NA03801202CBC } \\
\text { NA03801011ACC } \\
\text { NA03801206AAA } \\
\text { NA03901132CCC }\end{array}$ & $\begin{array}{l}\text { GW } \\
\text { GW } \\
\text { GW } \\
\text { GW } \\
\text { GW }\end{array}$ & $\begin{array}{l}09-09-68 \\
08-05-68 \\
07-03-68 \\
08-08-68 \\
08-07-68\end{array}$ & $\begin{array}{r}18 \\
18 \\
1,500 \\
28 \\
21\end{array}$ & $\begin{array}{l}-- \\
-- \\
-- \\
--\end{array}$ & $\begin{array}{r}9.0 \\
12.0 \\
31.0 \\
13.0 \\
11.0\end{array}$ & $\begin{array}{r}630 \\
132 \\
316 \\
13,800 \\
1,120\end{array}$ & $\begin{array}{l}-- \\
-- \\
-- \\
--\end{array}$ \\
\hline $\begin{array}{l}66 \\
67 \\
68 \\
69 \\
70\end{array}$ & $\begin{array}{l}37^{\circ} 35^{\prime} 02^{\prime \prime} \\
37^{\circ} 35^{\prime} 02^{\prime \prime} \\
37^{\circ} 35^{\prime} 02^{\prime \prime} \\
37^{\circ} 36^{\prime} 16^{\prime \prime} \\
37^{\circ} 36^{\prime \prime} 18^{\prime \prime}\end{array}$ & $\begin{array}{l}105^{\circ} 44^{\prime} 01^{\prime \prime} \\
105^{\circ} 44^{\prime} 01^{\prime \prime} \\
105^{\circ} 44^{\prime} 01^{\prime \prime} \\
105^{\circ} 42^{\prime} 42^{\prime \prime} \\
105^{\circ} 48^{\prime} 02^{\prime \prime}\end{array}$ & $\begin{array}{ll}01 & 1 \\
01 & 1 \\
01 & 1 \\
01 & 1 \\
01 & 1\end{array}$ & $\begin{array}{l}\text { NA03901135ADC1 } \\
\text { NA03901135ADC1 } \\
\text { NA03901135ADC } 1 \\
\text { NA03901125AAA } \\
\text { NA03901120CCC }\end{array}$ & $\begin{array}{l}\text { GW } \\
\text { GW } \\
\text { GW } \\
\text { GW } \\
\text { GW }\end{array}$ & $\begin{array}{l}11-01-68 \\
11-01-68 \\
11-01-68 \\
08-08-68 \\
08-07-68\end{array}$ & $\begin{array}{l}29 \\
29 \\
29 \\
20 \\
21\end{array}$ & $\begin{array}{l}-- \\
-- \\
-- \\
--\end{array}$ & $\begin{array}{l}10.0 \\
10.0 \\
10.0 \\
11.0 \\
11.0\end{array}$ & $\begin{array}{r}32,300 \\
32,100 \\
32,000 \\
2,340 \\
2,140\end{array}$ & $\begin{array}{l}-- \\
-- \\
-- \\
--\end{array}$ \\
\hline $\begin{array}{l}71 \\
72 \\
73 \\
74 \\
75\end{array}$ & $\begin{array}{l}37^{\circ} 36^{\prime} 20^{\prime \prime} \\
37^{\circ} 37^{\prime} 05^{\prime \prime} \\
37^{\circ} 38^{\prime} 00^{\prime \prime} \\
37^{\circ} 37^{\prime} 59^{\prime \prime} \\
37^{\circ} 38^{\prime} 04^{\prime \prime}\end{array}$ & $\begin{array}{l}106^{\circ} 05^{\prime} 40^{\prime \prime} \\
105^{\circ} 47^{\prime} 07^{\prime \prime} \\
105^{\circ} 45^{\prime} 55^{\prime \prime} \\
105^{\circ} 48^{\prime} 00^{\prime \prime} \\
105^{\circ} 42^{\prime} 19^{\prime \prime}\end{array}$ & $\begin{array}{ll}01 & 1 \\
01 & 1 \\
01 & 1 \\
01 & 1 \\
01 & 1\end{array}$ & $\begin{array}{l}\text { NA03900821DDA } \\
\text { NA03901120AAA } \\
\text { NA03901116AAA } \\
\text { NA03901117BBB } \\
\text { NA03901207CDC }\end{array}$ & $\begin{array}{l}\text { GW } \\
\text { GW } \\
\text { GW } \\
\text { GW } \\
\text { GW }\end{array}$ & $\begin{array}{l}07-26-68 \\
08-07-68 \\
08-06-68 \\
08-06-68 \\
08-08-68\end{array}$ & $\begin{array}{r}986 \\
22 \\
16 \\
16 \\
18\end{array}$ & $\begin{array}{l}-- \\
-- \\
-- \\
--\end{array}$ & $\begin{array}{l}13.0 \\
11.0 \\
12.0 \\
11.0 \\
10.0\end{array}$ & $\begin{array}{r}125 \\
3,280 \\
2,280 \\
790 \\
189\end{array}$ & $\begin{array}{l}-- \\
-- \\
-- \\
--\end{array}$ \\
\hline $\begin{array}{l}76 \\
77 \\
78 \\
79 \\
80\end{array}$ & $\begin{array}{l}37^{\circ} 37^{\prime} 48^{\prime \prime} \\
37^{\circ} 38^{\prime} 31^{\prime \prime} \\
37^{\circ} 39^{\prime} 50^{\prime \prime} \\
37^{\circ} 39^{\prime} 49^{\prime \prime} \\
37^{\circ} 39^{\prime} 49^{\prime \prime}\end{array}$ & $\begin{array}{l}105^{\circ} 51^{\prime} 15^{\prime \prime} \\
105^{\circ} 39^{\prime} 08^{\prime \prime} \\
105^{\circ} 39^{\prime} 23^{\prime \prime} \\
105^{\circ} 41^{\prime} 26^{\prime \prime} \\
105^{\circ} 41^{\prime} 26^{\prime \prime}\end{array}$ & $\begin{array}{ll}01 & 1 \\
01 & 1 \\
01 & 1 \\
01 & 1 \\
02 & 1\end{array}$ & $\begin{array}{l}\text { NA03901014BCC } \\
\text { NA03901210BCD } \\
\text { NA04001233DDD } \\
\text { NA04001232CCC1 } \\
\text { NA04001232CCC2 }\end{array}$ & $\begin{array}{l}\text { GW } \\
\text { GW } \\
\text { GW } \\
\text { GW } \\
\text { GW }\end{array}$ & $\begin{array}{l}08-28-79 \\
08-06-68 \\
08-06-68 \\
08-06-68 \\
08-06-68\end{array}$ & $\begin{array}{r}2,150 \\
22 \\
12 \\
56 \\
11\end{array}$ & $\begin{array}{r}350 \\
-- \\
-- \\
-- \\
--\end{array}$ & $\begin{array}{r}35.5 \\
11.0 \\
9.0 \\
13.0 \\
12.0\end{array}$ & $\begin{array}{l}425 \\
234 \\
175 \\
154 \\
499\end{array}$ & $\begin{array}{l}-- \\
-- \\
-- \\
--\end{array}$ \\
\hline $\begin{array}{l}81 \\
82 \\
83 \\
84 \\
85\end{array}$ & $\begin{array}{l}37^{\circ} 39^{\prime} 36^{\prime \prime} \\
37^{\circ} 39^{\prime} 44^{\prime \prime} \\
37^{\circ} 39^{\prime} 50^{\prime \prime} \\
37^{\circ} 39^{\prime} 41^{\prime \prime} \\
37^{\circ} 39^{\prime} 39^{\prime \prime}\end{array}$ & $\begin{array}{l}106^{\circ} 08^{\prime} 48^{\prime \prime} \\
106^{\circ} 05^{\prime} 24^{\prime \prime} \\
105^{\circ} 43^{\prime} 55^{\prime \prime} \\
105^{\circ} 55^{\prime} 38^{\prime \prime} \\
105^{\circ} 55^{\prime} 37^{\prime \prime}\end{array}$ & $\begin{array}{ll}01 & 1 \\
01 & 1 \\
01 & 1 \\
02 & 1 \\
01 & N\end{array}$ & $\begin{array}{l}\text { NA03900806BBB } \\
\text { NA04000834CCD } \\
\text { NA04001135DDC } \\
\text { NA03901006BBB2 } \\
\text { NA03901006BBB }\end{array}$ & $\begin{array}{l}\text { GW } \\
\text { GW } \\
\text { GW } \\
\text { GW } \\
\text { GW }\end{array}$ & $\begin{array}{l}09-06-68 \\
09-06-68 \\
08-06-68 \\
07-31-80 \\
08-09-68\end{array}$ & $\begin{array}{r}14 \\
13 \\
18 \\
1,991 \\
28\end{array}$ & $\begin{array}{l}-- \\
-- \\
-- \\
--\end{array}$ & $\begin{array}{l}14.0 \\
14.0 \\
12.0 \\
29.5 \\
31.0\end{array}$ & $\begin{array}{r}309 \\
270 \\
1,920 \\
312 \\
365\end{array}$ & $\begin{array}{l}-- \\
-- \\
-- \\
--\end{array}$ \\
\hline $\begin{array}{l}86 \\
87 \\
88 \\
89 \\
90\end{array}$ & $\begin{array}{l}37^{\circ} 39^{\prime} 44^{\prime \prime} \\
37^{\circ} 39^{\prime} 46^{\prime \prime} \\
37^{\circ} 39^{\prime} 47^{\prime \prime} \\
37^{\circ} 39^{\prime} 51^{\prime \prime} \\
37^{\circ} 40^{\prime} 12^{\prime \prime}\end{array}$ & $\begin{array}{l}106^{\circ} 02^{\prime} 20^{\prime \prime} \\
105^{\circ} 39^{\prime} 08^{\prime \prime} \\
105^{\circ} 49^{\prime} 07^{\prime \prime} \\
106^{\circ} 00^{\prime} 20^{\prime \prime} \\
105^{\circ} 41^{\prime} 04^{\prime \prime}\end{array}$ & $\begin{array}{ll}01 & 1 \\
01 & 1 \\
01 & 1 \\
01 & 1 \\
01 & N\end{array}$ & $\begin{array}{l}\text { NA0 4000931CCC } \\
\text { NA03901203BBA1 } \\
\text { NA03901106BBB } \\
\text { NA04000932DAA } \\
\text { NA04001232BAA }\end{array}$ & $\begin{array}{l}\text { GW } \\
\text { GW } \\
\text { GW } \\
\text { GW } \\
\text { GW }\end{array}$ & $\begin{array}{l}03-25-81 \\
08-23-78 \\
05-08-80 \\
07-31-80 \\
05-08-80\end{array}$ & $\begin{array}{l}28.0 \\
144 \\
27 \\
77.0 \\
30\end{array}$ & $\begin{array}{l}-- \\
-- \\
-- \\
--\end{array}$ & $\begin{array}{r}13.5 \\
15.0 \\
9.5 \\
10.5 \\
9.5\end{array}$ & $\begin{array}{l}278 \\
160 \\
715 \\
900 \\
410\end{array}$ & $\begin{array}{r}274 \\
-- \\
-- \\
-- \\
--\end{array}$ \\
\hline 91 & $37^{\circ} 40^{\prime} 53^{\prime \prime}$ & $106^{\circ} 21^{\prime} 55^{\prime \prime}$ & $01 N$ & \multirow{2}{*}{$\begin{array}{l}\text { NA04000630CBB } \\
\text { Wagon Wheel Gap } \\
\text { Hot Springs }\end{array}$} & GW & $08-29-79$ & 120 & 1,000 & 9.5 & 475 & -- \\
\hline 92 & $37^{\circ} 41^{\prime} 02^{\prime \prime}$ & $106^{\circ} 49^{\prime} 47^{\prime \prime}$ & 00 & & SP & $10-21-75$ & - & 50 & 51.0 & 2,400 & -- \\
\hline
\end{tabular}


Table 4.--Water-quality information from selected wells and springs in the $S$ an Luis basin in Colorado and New Mexico--Continued

\begin{tabular}{|c|c|c|c|c|c|c|c|c|c|c|c|}
\hline $\begin{array}{l}\text { Site } \\
\text { obser- } \\
\text { vation } \\
\text { number }\end{array}$ & Latitude & Longitude & $\begin{array}{l}\text { Se- } \\
\text { quence } \\
\text { num- } \\
\text { ber }\end{array}$ & $\underset{\text { identifier }}{\text { Local }}$ & $\begin{array}{l}\text { Sample } \\
\text { source }\end{array}$ & $\begin{array}{l}\text { Date of } \\
\text { sample } \\
\text { (mo/d/yr) }\end{array}$ & $\begin{array}{l}\text { Depth } \\
\text { to } \\
\text { water } \\
\text { (feet) }\end{array}$ & $\begin{array}{l}\text { Flow } \\
\text { rate } \\
\text { (gal/min) }\end{array}$ & $\begin{array}{l}\text { Temper- } \\
\text { ature } \\
\left({ }^{\circ} \mathrm{C}\right)\end{array}$ & $\begin{array}{c}\text { Spe- } \\
\text { cific } \\
\text { con- } \\
\text { duct- } \\
\text { ance, } \\
\text { field } \\
(\mu S / \mathrm{cm})\end{array}$ & $\begin{array}{c}\text { Spe- } \\
\text { cific } \\
\text { con- } \\
\text { duct- } \\
\text { ance, } \\
\text { labor- } \\
\text { atory } \\
(\mu S / \mathrm{cm})\end{array}$ \\
\hline 93 & $37^{\circ} 41^{\prime} 02^{\prime \prime}$ & $106^{\circ} 49^{\prime} 47^{\prime \prime}$ & 00 & $\begin{array}{l}\text { Wagon Wheel Gap } \\
\text { Hot Springs }\end{array}$ & $\mathrm{SP}$ & $01-27-76$ & -- & 30 & 48.0 & 2,240 & -- \\
\hline 94 & $37^{\circ} 41^{\prime} 02^{\prime \prime}$ & $106^{\circ} 49^{\prime} 47^{\prime \prime}$ & 00 & $\begin{array}{l}\text { Wagon Wheel Gap } \\
\text { Hot Springs }\end{array}$ & $\mathrm{SP}$ & $04-21-76$ & -- & 32 & 50.0 & 2,000 & -- \\
\hline 95 & $37^{\circ} 41^{\prime} 06^{\prime \prime}$ & $106^{\circ} 49^{\prime} 47^{\prime \prime}$ & 00 & $\begin{array}{l}\text { Wagon Wheel Gap } \\
\text { Hot Springs }\end{array}$ & $\mathrm{sP}$ & $08-13-75$ & -- & -- & 56.5 & 3,400 & -- \\
\hline 96 & $37^{\circ} 41^{\prime} 06^{\prime \prime}$ & $106^{\circ} 49^{\prime} 47^{\prime \prime}$ & 00 & $\begin{array}{l}\text { Wagon Wheel Gap } \\
\text { Hot Springs }\end{array}$ & $\mathrm{SP}$ & $10-21-75$ & -- & 30 & 57.0 & 2,400 & -- \\
\hline 97 & $37^{\circ} 41^{\prime} 06^{\prime \prime}$ & $106^{\circ} 49^{\prime} 47^{\prime \prime}$ & 00 & $\begin{array}{l}\text { Wagon Wheel Gap } \\
\text { Hot Springs }\end{array}$ & $\mathrm{sP}$ & $01-27-76$ & -- & 30 & 55.0 & 2,350 & -- \\
\hline 98 & $37^{\circ} 41^{\prime} 06^{\prime \prime}$ & $106^{\circ} 49^{\prime} 47^{\prime \prime}$ & 00 & $\begin{array}{l}\text { Wagon Wheel Gap } \\
\text { Hot Springs }\end{array}$ & $\mathrm{SP}$ & $04-18-76$ & -- & 28 & 57.0 & 2,200 & -- \\
\hline 99 & $37^{\circ} 42^{\prime} 15^{\prime \prime}$ & $105^{\circ} 52^{\prime} 15^{\prime \prime}$ & 011 & NA0 $4001022 B B B$ & GW & $07-18-68$ & 2,063 & -- & 31.0 & 454 & -- \\
\hline 100 & $37^{\circ} 43^{\prime} 43^{\prime \prime}$ & $107^{\circ} 03^{\prime} 16^{\prime \prime}$ & 00 & $\begin{array}{l}\text { Birdsey Warm } \\
\text { Spring }\end{array}$ & SP & $08-20-76$ & -- & 15 & 30.0 & 200 & -- \\
\hline $\begin{array}{l}101 \\
102 \\
103 \\
104 \\
105\end{array}$ & $\begin{array}{l}37^{\circ} 44^{\prime} 09^{\prime \prime} \\
37^{\circ} 45^{\prime} 03^{\prime \prime} \\
37^{\circ} 50^{\prime} 16^{\prime \prime} \\
37^{\circ} 46^{\prime} 48^{\prime \prime} \\
37^{\circ} 48^{\prime} 20^{\prime \prime}\end{array}$ & $\begin{array}{l}105^{\circ} 45^{\prime} 50^{\prime \prime} \\
105^{\circ} 49^{\prime} 07^{\prime \prime} \\
106^{\circ} 02^{\prime} 12^{\prime \prime} \\
105^{\circ} 51^{\prime} 19^{\prime \prime} \\
105^{\circ} 49^{\prime} 26^{\prime \prime}\end{array}$ & $\begin{array}{ll}01 & 1 \\
01 & 1 \\
01 & 1 \\
01 & 1 \\
01 & 1\end{array}$ & $\begin{array}{l}\text { NA04001109AAA1 } \\
\text { NA04101036DDD } \\
\text { NA04200931CCC1 } \\
\text { NA04101027AAA } \\
\text { NA04101013ABD }\end{array}$ & $\begin{array}{l}\text { GW } \\
\text { GW } \\
\text { GW } \\
\text { GW } \\
\text { GW }\end{array}$ & $\begin{array}{l}08-23-78 \\
09-06-68 \\
07-11-68 \\
08-23-78 \\
09-06-68\end{array}$ & $\begin{array}{r}98.0 \\
12 \\
1,347 \\
125 \\
9\end{array}$ & $\begin{array}{l}-- \\
-- \\
-- \\
-- \\
--\end{array}$ & $\begin{array}{l}17.0 \\
12.0 \\
18.0 \\
15.0 \\
12.0\end{array}$ & $\begin{array}{l}180 \\
678 \\
214 \\
700 \\
401\end{array}$ & $\begin{array}{l}-- \\
-- \\
-- \\
--\end{array}$ \\
\hline $\begin{array}{l}106 \\
107 \\
108 \\
109 \\
110\end{array}$ & $\begin{array}{l}37^{\circ} 48^{\prime} 21^{\prime \prime} \\
37^{\circ} 50^{\prime} 09^{\prime \prime} \\
37^{\circ} 50^{\prime} 09^{\prime \prime} \\
37^{\circ} 50^{\prime} 13^{\prime \prime} \\
37^{\circ} 50^{\prime} 20^{\prime \prime}\end{array}$ & $\begin{array}{l}105^{\circ} 49^{\prime} 27^{\prime \prime} \\
105^{\circ} 55^{\prime} 43^{\prime \prime} \\
105^{\circ} 55^{\prime} 43^{\prime \prime} \\
105^{\circ} 51^{\prime} 57^{\prime \prime} \\
105^{\circ} 50^{\prime} 04^{\prime \prime}\end{array}$ & $\begin{array}{ll}01 & 1 \\
01 & 1 \\
01 & 1 \\
01 & 1 \\
01 & 1\end{array}$ & $\begin{array}{l}\text { NA04101013ABD1 } \\
\text { NA04200936DDD } \\
\text { NA04200936DDD } \\
\text { NA04201034CDD1 } \\
\text { NA04201036CCD1 }\end{array}$ & $\begin{array}{l}\text { GW } \\
\text { GW } \\
\text { GW } \\
\text { GW } \\
\text { GW }\end{array}$ & $\begin{array}{l}08-23-78 \\
05-08-80 \\
03-25-81 \\
08-01-80 \\
08-23-78\end{array}$ & $\begin{array}{r}105 \\
2,087 \\
24 \\
600 \\
97\end{array}$ & $\begin{array}{l}-- \\
-- \\
-- \\
-- \\
--\end{array}$ & $\begin{array}{r}16.0 \\
9.5 \\
10.0 \\
14.0 \\
13.0\end{array}$ & $\begin{array}{r}220 \\
1,180 \\
1,170 \\
2,600 \\
700\end{array}$ & $\begin{array}{l}-- \\
-- \\
1,180 \\
-- \\
--\end{array}$ \\
\hline $\begin{array}{l}111 \\
112 \\
113 \\
114 \\
115\end{array}$ & $\begin{array}{l}37^{\circ} 52^{\prime} 12^{\prime \prime} \\
37^{\circ} 53^{\prime} 10^{\prime \prime} \\
37^{\circ} 55^{\prime} 24^{\prime \prime} \\
37^{\circ} 57^{\prime} 00^{\prime \prime} \\
37^{\circ} 57^{\prime} 07^{\prime \prime}\end{array}$ & $\begin{array}{l}105^{\circ} 55^{\prime} 41^{\prime \prime} \\
106^{\circ} 04^{\prime} 44^{\prime \prime} \\
106^{\circ} 02^{\prime} 05^{\prime \prime} \\
105^{\circ} 55^{\prime} 28^{\prime \prime} \\
105^{\circ} 59^{\prime} 55^{\prime \prime}\end{array}$ & $\begin{array}{ll}01 & 1 \\
01 & 1 \\
01 & 1 \\
01 & 1 \\
01 & 1\end{array}$ & $\begin{array}{l}\text { NA04200924DAD1 } \\
\text { NA04200815ACC } \\
\text { NA04300931CCC } \\
\text { NA04301019CCC } \\
\text { NA04300920DDD }\end{array}$ & $\begin{array}{l}\text { GW } \\
\text { GW } \\
\text { GW } \\
\text { GW } \\
\text { GW }\end{array}$ & $\begin{array}{l}08-23-78 \\
09-12-68 \\
05-08-80 \\
12-17-68 \\
09-06-68\end{array}$ & $\begin{array}{r}105 \\
2,087 \\
30 \\
13 \\
15\end{array}$ & $\begin{array}{l}-- \\
-- \\
-- \\
-- \\
--\end{array}$ & $\begin{array}{r}18.0 \\
18.0 \\
9.5 \\
18.0 \\
10.0\end{array}$ & $\begin{array}{r}230 \\
151 \\
920 \\
1,480 \\
490\end{array}$ & $\begin{array}{l}-- \\
-- \\
-- \\
--\end{array}$ \\
\hline $\begin{array}{l}116 \\
117 \\
118 \\
119 \\
120\end{array}$ & $\begin{array}{l}37^{\circ} 58^{\prime} 02^{\prime \prime} \\
37^{\circ} 58^{\prime} 41^{\prime \prime} \\
37^{\circ} 59^{\prime} 35^{\prime \prime} \\
37^{\circ} 59^{\prime} 39^{\prime \prime} \\
38^{\circ} 00^{\prime} 02^{\prime \prime}\end{array}$ & $\begin{array}{l}106^{\circ} 05^{\prime} 25^{\prime \prime} \\
105^{\circ} 43^{\prime} 35^{\prime \prime} \\
105^{\circ} 58^{\prime} 20^{\prime \prime} \\
106^{\circ} 02^{\prime} 01^{\prime \prime} \\
105^{\circ} 46^{\prime} 23^{\prime \prime}\end{array}$ & $\begin{array}{ll}01 & 1 \\
01 & 1 \\
01 & 1 \\
01 & 1 \\
01 & 1\end{array}$ & $\begin{array}{l}\text { NA04300816DDD } \\
\text { NA04301114DAD } \\
\text { NA04300910BAB } \\
\text { NA04300907BBB2 } \\
\text { NA04301109BBA }\end{array}$ & $\begin{array}{l}\mathrm{GW} \\
\mathrm{GW} \\
\mathrm{GW} \\
\mathrm{GW} \\
\mathrm{GW}\end{array}$ & $\begin{array}{l}09-06-68 \\
07-30-80 \\
08-06-68 \\
07-31-80 \\
07-30-80\end{array}$ & $\begin{array}{r}9 \\
250 \\
1,058 \\
27 \\
180\end{array}$ & $\begin{array}{l}-- \\
-- \\
-- \\
--\end{array}$ & $\begin{array}{r}8.0 \\
10.0 \\
17.0 \\
9.0 \\
11.0\end{array}$ & $\begin{array}{l}964 \\
360 \\
225 \\
435 \\
170\end{array}$ & $\begin{array}{l}-- \\
-- \\
-- \\
--\end{array}$ \\
\hline $\begin{array}{l}121 \\
122 \\
123\end{array}$ & $\begin{array}{l}38^{\circ} 00^{\prime} 23^{\prime \prime} \\
38^{\circ} 05^{\prime} 20^{\prime \prime} \\
38^{\circ} 06^{\prime} 00^{\prime \prime}\end{array}$ & $\begin{array}{l}105^{\circ} 55^{\prime} 17^{\prime \prime} \\
106^{\circ} 11^{\prime} 16^{\prime \prime} \\
105^{\circ} 59^{\prime} 44^{\prime \prime}\end{array}$ & $\begin{array}{ll}01 & 1 \\
01 & 1 \\
01 & 1\end{array}$ & $\begin{array}{l}\text { NA04301006BCC } \\
\text { NA044007 10BAA } \\
\text { NA04400905AAA }\end{array}$ & $\begin{array}{l}\text { GW } \\
\text { GW } \\
\text { GW }\end{array}$ & $\begin{array}{l}07-29-80 \\
09-06-68 \\
08-21-68\end{array}$ & $\begin{array}{c}18.5 \\
9 \\
280\end{array}$ & $\begin{array}{l}-- \\
-- \\
--\end{array}$ & $\begin{array}{r}8.0 \\
11.0 \\
14.0\end{array}$ & $\begin{array}{r}3,000 \\
431 \\
263\end{array}$ & $\begin{array}{l}-- \\
--\end{array}$ \\
\hline 124 & $38^{\circ} 10^{\prime} 04^{\prime \prime}$ & $105^{\circ} 55^{\prime} 20^{\prime \prime}$ & 00 & $\begin{array}{c}\text { Mineral Hot } \\
\text { Spring D }\end{array}$ & SP & $10-09-75$ & -- & -- & 60.0 & 1,000 & - \\
\hline 125 & $38^{\circ} 10^{\prime} 04^{\prime \prime}$ & $105^{\circ} 55^{\prime} 20^{\prime \prime}$ & 00 & $\begin{array}{c}\text { Mineral Hot } \\
\text { Spring D }\end{array}$ & SP & $01-25-76$ & -- & 5.0 & 60.0 & 950 & -- \\
\hline 126 & $38^{\circ} 10^{\prime} 04^{\prime \prime}$ & $105^{\circ} 55^{\prime} 20^{\prime \prime}$ & 00 & $\begin{array}{c}\text { Mineral Hot } \\
\text { Spring D }\end{array}$ & SP & $04-20-76$ & -- & -- & 60.0 & 930 & -- \\
\hline 127 & $38^{\circ} 10^{\prime} 08^{\prime \prime}$ & $105^{\circ} 55^{\prime} 05^{\prime \prime}$ & 00 & $\begin{array}{c}\text { Mineral Hot } \\
\text { Spring A }\end{array}$ & SP & $10-09-75$ & -- & 167 & 60.0 & 1,000 & -- \\
\hline 128 & $38^{\circ} 10^{\prime} 08^{\prime \prime}$ & $105^{\circ} 55^{\prime} 05^{\prime \prime}$ & 00 & $\begin{array}{c}\text { Mineral Hot } \\
\text { Spring A }\end{array}$ & SP & $01-25-76$ & -- & 70 & 60.0 & 960 & -- \\
\hline 129 & $38^{\circ} 10^{\prime} 08^{\prime \prime}$ & $105^{\circ} 55^{\prime} 05^{\prime \prime}$ & 00 & $\begin{array}{c}\text { Mineral Hot } \\
\text { Spring A }\end{array}$ & SP & $04-20-76$ & -- & 95 & 60.0 & 1,100 & -- \\
\hline 130 & $38^{\circ} 17^{\prime} 42^{\prime \prime}$ & $105^{\circ} 57^{\prime} 18^{\prime \prime}$ & 011 & NA04700926CCB & GW & $07-29-80$ & 99 & -- & 10.0 & 277 & -- \\
\hline 131 & $38^{\circ} 18^{\prime} 18^{\prime \prime}$ & $105^{\circ} 58^{\prime} 55^{\prime \prime}$ & 00 & $\begin{array}{l}\text { Fullinwider } \\
\text { Warm Spring }\end{array}$ & SP & $10-23-75$ & -- & 11 & 18.0 & 530 & -- \\
\hline
\end{tabular}


Table 4.--Water-quality information from selected wells and springs in the San Luis basin in Colorado and New Mexico--Continued

\begin{tabular}{|c|c|c|c|c|c|c|c|c|c|c|c|c|c|}
\hline $\begin{array}{l}\text { Site } \\
\text { obser- } \\
\text { vation } \\
\text { number }\end{array}$ & $\begin{array}{c}\text { Date } \\
\text { of } \\
\text { sample } \\
\text { (mo/d/yr) }\end{array}$ & $\begin{array}{c}\mathrm{pH} \\
\text { field } \\
\text { (stand- } \\
\text { ard } \\
\text { units) }\end{array}$ & $\begin{array}{l}\mathrm{pH}, \\
\text { labor- } \\
\text { atory } \\
\text { (stand- } \\
\text { ard } \\
\text { units) }\end{array}$ & $\begin{array}{c}\text { Carbon } \\
\text { diox- } \\
\text { ide, } \\
\text { dis- } \\
\text { solved } \\
(\mathrm{mg} / \mathrm{L} \\
\left.\text { as } \mathrm{CO}_{2}\right)\end{array}$ & $\begin{array}{l}\text { Hard- } \\
\text { ness } \\
(\mathrm{mg} / \mathrm{L} \\
\text { as } \\
\mathrm{CaCO}_{3} \text { ) }\end{array}$ & $\begin{array}{l}\text { Hard- } \\
\text { ness, } \\
\text { noncar- } \\
\text { bonate } \\
\text { (mg/L } \\
\text { as } \\
\mathrm{CaCO}_{3} \text { ) }\end{array}$ & $\begin{array}{l}\text { Cal- } \\
\text { cium, } \\
\text { dis- } \\
\text { solved } \\
\text { (mg/L } \\
\text { as Ca) }\end{array}$ & $\begin{array}{l}\text { Magne- } \\
\text { sium, } \\
\text { dis- } \\
\text { solved } \\
\text { (mg/L } \\
\text { as } \mathrm{Mg} \text { ) }\end{array}$ & $\begin{array}{l}\text { Potas- } \\
\text { sium, } \\
\text { dis- } \\
\text { solved } \\
\text { (mg/L } \\
\text { as K) }\end{array}$ & $\begin{array}{l}\text { Sodium, } \\
\text { dis- } \\
\text { solved } \\
\text { (mg/L } \\
\text { as } \mathrm{Na})\end{array}$ & $\begin{array}{l}\text { Per- } \\
\text { cent } \\
\text { so- } \\
\text { dium }\end{array}$ & $\begin{array}{l}\text { Sodium } \\
\text { adsorp- } \\
\text { tion } \\
\text { ratio }\end{array}$ & $\begin{array}{c}\text { Bicar- } \\
\text { bonate } \\
\text { (mg/L } \\
\text { as } \\
\left.\mathrm{HcO}_{3}\right)\end{array}$ \\
\hline 1 & $03-08-83$ & 7.7 & 8.2 & 6.9 & 39 & 0 & 14 & 0.90 & 1.8 & 88 & 82 & 6 & -- \\
\hline 2 & $11-17-81$ & 8.0 & 8.0 & 5.4 & 220 & 0 & 68 & 12 & 6.4 & 49 & 32 & 1 & -- \\
\hline 3 & $07-23-76$ & 7.5 & $\cdots$ & 7.0 & 120 & 3 & 38 & 5.6 & 3.4 & 39 & 41 & 2 & 140 \\
\hline 4 & $09-06-79$ & 7.3 & - & 22 & 240 & 7 & 75 & 12 & 1.0 & 14 & 11 & .4 & 280 \\
\hline 5 & $07-22-76$ & 8.0 & -- & 3.2 & 71 & 0 & 21 & 4.6 & 11 & 150 & 79 & 8 & 200 \\
\hline 6 & $08-19-82$ & 7.9 & 8.3 & 2.0 & 97 & 15 & 28 & 6.6 & 3.1 & 10 & 18 & .5 & 100 \\
\hline 7 & $08-19-82$ & 7.9 & 8.3 & 1.8 & 68 & 0 & 19 & 5.0 & 2.7 & 21 & 39 & 1 & 92 \\
\hline 8 & $08-20-82$ & 8.1 & 8.3 & 1.1 & 71 & 0 & 20 & 5.1 & 2.5 & 20 & 37 & 1 & 92 \\
\hline 9 & $09-06-79$ & 8.2 & $\cdots$ & 1.0 & 59 & 0 & 16 & 4.6 & 2.6 & 19 & 40 & 1 & 100 \\
\hline 10 & $03-09-66$ & 7.2 & -- & 17 & 180 & 45 & 57 & 10 & 2.0 & 15 & 15 & .5 & 170 \\
\hline 11 & $06-01-81$ & 7.5 & 7.9 & 4.7 & 58 & 0 & 16 & 4.4 & 2.6 & 12 & 30 & .7 & -- \\
\hline 12 & $08-13-80$ & 8.0 & -- & 2.2 & 110 & 0 & 37 & 5.3 & 1.0 & 7.7 & 13 & .3 & 140 \\
\hline 13 & $06-26-68$ & 7.3 & -. & 6.4 & 90 & 25 & 27 & 5.6 & 1.1 & 6.7 & 14 & .3 & 80 \\
\hline 14 & $06-04-82$ & 7.9 & 7.9 & 2.1 & 77 & 0 & 24 & 4.1 & 2.9 & 5.6 & 13 & .3 & $\cdots$ \\
\hline 15 & $06-04-82$ & 8.0 & 7.6 & 1.8 & 88 & 0 & 27 & 5.1 & 3.1 & 5.7 & 12 & .3 & -- \\
\hline 16 & $06-04-82$ & 8.2 & 8.0 & .9 & 69 & 0 & 21 & 3.9 & 2.3 & 5.9 & 15 & .3 & -- \\
\hline 17 & $06-04-82$ & 8.4 & 8.1 & .9 & 99 & 0 & 27 & 7.6 & 3.0 & 13 & 22 & .6 & -- \\
\hline 18 & $08-29-79$ & 7.0 & $\cdots$ & 20 & 110 & 6 & 32 & 6.3 & 3.3 & 5.0 & 9 & .2 & 120 \\
\hline 19 & $09-09-68$ & 8.0 & -- & 2.3 & 120 & 0 & 45 & 1.2 & 5.0 & 2.5 & 4 & .1 & 140 \\
\hline 20 & $09-10-68$ & 8.3 & -- & .8 & 89 & 7 & 30 & 3.4 & 1.3 & 4.2 & 9 & .2 & 100 \\
\hline 21 & $06-03-82$ & 8.0 & 8.1 & 1.4 & 61 & 0 & 18 & 3.9 & 2.0 & 4.6 & 14 & .3 & -- \\
\hline 22 & $06-02-82$ & 8.2 & 8.0 & 1.0 & 69 & 0 & 21 & 4.1 & 2.3 & 5.3 & 14 & .3 & -. \\
\hline 23 & $09-10-68$ & 8.3 & -- & 1.7 & 170 & 0 & 62 & 2.9 & 3.5 & 18 & 19 & .6 & 210 \\
\hline 24 & $08-08-68$ & 8.1 & -- & 1.1 & 69 & 0 & 20 & 4.6 & 2.4 & 7.8 & 19 & .4 & 91 \\
\hline 25 & $05-14-68$ & 8.0 & $\cdots$ & 3.0 & 180 & 20 & 49 & 13 & 1.6 & 17 & 17 & .6 & 190 \\
\hline 26 & $09-09-68$ & 8.1 & -- & 3.5 & 150 & 0 & 46 & 9.7 & 5.1 & 85 & 53 & 3 & 280 \\
\hline 27 & $04-19-76$ & 6.9 & -- & 15 & 70 & 8 & 23 & 3.1 & 5.0 & 8.9 & 20 & .5 & 75 \\
\hline 28 & $06-07-68$ & 8.0 & $\cdots$ & 1.9 & 88 & 0 & 24 & 6.8 & 2.4 & 14 & 25 & .7 & 120 \\
\hline 29 & $08-20-68$ & 8.1 & -- & 2.0 & 99 & 0 & 32 & 4.6 & 5.4 & 53 & 52 & 2 & 160 \\
\hline 30 & $07-23-80$ & 7.7 & -- & 5.0 & 83 & 0 & 25 & 5.0 & 6.1 & 52 & 55 & 3 & 160 \\
\hline 31 & $04-19-76$ & 7.9 & -- & 1.9 & 38 & 0 & 12 & 1.9 & 8.4 & 28 & 56 & 2 & 94 \\
\hline 32 & $08-19-68$ & 7.9 & -- & 2.8 & 21 & 0 & 7.6 & .50 & 7.4 & 51 & 78 & 5 & 140 \\
\hline 33 & $06-18-68$ & 8.1 & -- & 2.5 & 170 & 6 & 53 & 9.2 & 3.8 & 14 & 15 & .5 & 200 \\
\hline 34 & $06-26-68$ & 7.4 & -- & 8.2 & 120 & 17 & 35 & 8.8 & 1.0 & 6.2 & 10 & .3 & 130 \\
\hline 35 & $07-22-80$ & 7.6 & - & 7.3 & 140 & 0 & 43 & 7.7 & 4.1 & 14 & 17 & .5 & 180 \\
\hline 36 & $05-07-68$ & 7.8 & -- & 2.8 & 65 & 0 & 22 & 2.4 & 11 & 17 & 32 & 1 & 110 \\
\hline 37 & $09-10-68$ & 8.4 & -- & 1.1 & 160 & 17 & 57 & 5.4 & .80 & 8.5 & 10 & .3 & 180 \\
\hline 38 & $07-22-80$ & 7.4 & $\cdots$ & 10 & 120 & 0 & 38 & 6.6 & 1.6 & 12 & 17 & .5 & 170 \\
\hline 39 & $07-18-68$ & 8.0 & -- & 1.9 & 83 & 0 & 28 & 3.2 & 6.6 & 22 & 34 & 1 & 120 \\
\hline 40 & $09-10-68$ & 8.0 & $\cdots$ & 2.4 & 100 & 0 & 36 & 2.9 & 2.3 & 44 & 48 & 2 & 150 \\
\hline 41 & $08-23-68$ & 8.4 & -- & 1.4 & 25 & 0 & 8.0 & 1.1 & 12 & 110 & 85 & 10 & 220 \\
\hline 42 & $06-07-68$ & 7.9 & -- & 1.9 & 88 & 9 & 28 & 4.4 & 1.1 & 7.0 & 15 & .3 & 96 \\
\hline 43 & $07-19-68$ & 8.1 & -- & 1.3 & 64 & 0 & 24 & 1.0 & 4.9 & 12 & 27 & .7 & 100 \\
\hline 44 & $08-05-68$ & 6.8 & -- & 50 & 74 & 0 & 23 & 4.1 & 5.7 & 47 & 56 & 2 & 200 \\
\hline 45 & $08-05-68$ & 6.6 & -- & 36 & 48 & 0 & 15 & 2.6 & .9 & 19 & 46 & 1 & 90 \\
\hline 46 & $08-05-68$ & 6.5 & -- & 55 & 55 & 0 & 14 & 4.8 & 2.0 & 19 & 42 & 1 & 110 \\
\hline 47 & $08-09-68$ & 7.8 & -- & 8.8 & 67 & 0 & 19 & 4.8 & 4.4 & 190 & 85 & 10 & 350 \\
\hline 48 & $08-12-75$ & 8.3 & -- & 1.1 & 12 & 0 & 4.1 & .40 & 9.9 & 72 & 86 & 10 & 150 \\
\hline 49 & $07-31-80$ & 7.0 & -- & 48 & 170 & 0 & 51 & 11 & 10 & 79 & 48 & 3 & - \\
\hline 50 & $08-05-68$ & 6.9 & $\cdots$ & 76 & 250 & 0 & 66 & 20 & 12 & 92 & 43 & 3 & 380 \\
\hline
\end{tabular}


Table 4.--Water-quality information from selected wells and springs in the San Luis basin in Colorado and New Mexico--Continued

\begin{tabular}{|c|c|c|c|c|c|c|c|c|c|c|c|c|c|}
\hline $\begin{array}{l}\text { Site } \\
\text { obser- } \\
\text { vation } \\
\text { number }\end{array}$ & $\begin{array}{c}\text { Date } \\
\text { of } \\
\text { sample } \\
\text { (mo/d/yr) }\end{array}$ & $\begin{array}{c}\mathrm{pH}, \\
\text { field } \\
\text { (stand- } \\
\text { ard } \\
\text { units) }\end{array}$ & $\begin{array}{l}\mathrm{pH}, \\
\text { labor- } \\
\text { atory } \\
\text { (stand- } \\
\text { ard } \\
\text { units) }\end{array}$ & $\begin{array}{c}\text { Carbon } \\
\text { diox- } \\
\text { ide, } \\
\text { dis- } \\
\text { solved } \\
\text { (mg/L } \\
\text { as } \mathrm{CO}_{2} \text { ) }\end{array}$ & $\begin{array}{l}\text { Hard- } \\
\text { ness } \\
(\mathrm{mg} / \mathrm{L} \\
\text { as } \\
\left.\mathrm{CaCO}_{3}\right)\end{array}$ & $\begin{array}{l}\text { Hard- } \\
\text { ness, } \\
\text { noncar- } \\
\text { bonate } \\
\text { (mg/L } \\
\text { as } \\
\left.\mathrm{CaCO}_{3}\right)\end{array}$ & $\begin{array}{l}\text { Cal- } \\
\text { cium, } \\
\text { dis- } \\
\text { solved } \\
\text { (mg/L } \\
\text { as Ca) }\end{array}$ & $\begin{array}{l}\text { Magne- } \\
\text { sium, } \\
\text { dis- } \\
\text { solved } \\
\text { (mg/L } \\
\text { as Mg) }\end{array}$ & $\begin{array}{l}\text { Potas- } \\
\text { sium, } \\
\text { dis- } \\
\text { solved } \\
\text { (mg/L } \\
\text { as K) }\end{array}$ & $\begin{array}{l}\text { Sodium, } \\
\text { dis- } \\
\text { solved } \\
\text { (mg/L } \\
\text { as } \mathrm{Na} \text { ) }\end{array}$ & $\begin{array}{l}\text { Per- } \\
\text { cent } \\
\text { so- } \\
\text { dium }\end{array}$ & $\begin{array}{l}\text { Sodium } \\
\text { adsorp- } \\
\text { tion } \\
\text { ratio }\end{array}$ & $\begin{array}{c}\text { Bicar- } \\
\text { bonate } \\
(\mathrm{mg} / \mathrm{L} \\
\text { as } \\
\left.\mathrm{HcO}_{3}\right)\end{array}$ \\
\hline 51 & $08-05-68$ & 6.9 & -- & 14 & 39 & 0 & 14 & 1.0 & 1.9 & 15 & 44 & 1 & 71 \\
\hline 52 & $08-05-68$ & 7.0 & -- & 17 & 87 & 0 & 31 & 2.4 & 1.5 & 20 & 33 & 1 & 110 \\
\hline 53 & $08-09-68$ & 7.6 & -- & 13 & 220 & 0 & 64 & 14 & 5.2 & 130 & 56 & 4 & 330 \\
\hline 54 & $08-05-68$ & 6.3 & -- & 135 & 450 & 314 & 130 & 31 & 14 & 260 & 55 & 6 & 170 \\
\hline 55 & $08-22-78$ & 8.5 & -- & .4 & 49 & 0 & 18 & 1.0 & 1.6 & 7.4 & 24 & .5 & -- \\
\hline 56 & $07-18-68$ & 8.6 & -- & .6 & 20 & 0 & 6.4 & 1.0 & 3.9 & 53 & 82 & 5 & 160 \\
\hline 57 & $08-07-68$ & 9.0 & -- & 1.3 & 540 & 0 & 160 & 35 & 16 & 550 & 68 & 11 & 840 \\
\hline 58 & $08-07-68$ & 6.8 & -- & 17 & 34 & 0 & 12 & 1.0 & 2.6 & 9.8 & 36 & .8 & 68 \\
\hline 59 & $08-09-68$ & 8.3 & -- & 3.4 & 250 & 0 & 64 & 22 & 11 & 150 & 55 & 4 & 430 \\
\hline 60 & $08-07-68$ & 6.8 & -- & 106 & 380 & 40 & 96 & 35 & 19 & 650 & 78 & 15 & 420 \\
\hline 61 & $09-09-68$ & 8.1 & - & 4.3 & 280 & 0 & 85 & 16 & 11 & 34 & 20 & .9 & 340 \\
\hline 62 & $08-05-68$ & 6.6 & -- & 32 & 60 & 0 & 21 & 1.9 & 1.1 & 4.7 & 14 & .3 & 79 \\
\hline 63 & $07-03-68$ & 8.6 & -- & .6 & 15 & 0 & 4.8 & .7 & 3.5 & 59 & 87 & 7 & 150 \\
\hline 64 & $08-08-68$ & 7.2 & - & 77 & 2,600 & 1,980 & 650 & 240 & 49 & 2,700 & 69 & 24 & 770 \\
\hline 65 & $08-07-68$ & 8.5 & -- & 3.6 & 53 & 0 & 16 & 3.2 & 5.9 & 260 & 90 & 16 & 720 \\
\hline 66 & $11-01-68$ & 8.3 & -- & 56 & 2,100 & 0 & 190 & 390 & 99 & 10,000 & 91 & 100 & 6,990 \\
\hline 67 & $11-01-68$ & 8.0 & -- & 114 & 2,100 & 0 & 180 & 390 & 96 & 10,000 & 91 & 100 & 7,150 \\
\hline 68 & $11-01-68$ & 7.8 & -- & 181 & 2,100 & 0 & 190 & 390 & 96 & 10,000 & 91 & 99 & 7,200 \\
\hline 69 & $08-08-68$ & 8.8 & -- & 2.7 & 16 & 0 & 4.4 & 1.1 & 12 & 550 & 97 & 62 & 1,070 \\
\hline 70 & $08-07-68$ & 8.4 & -- & 3.0 & 290 & 0 & 110 & 4.9 & 8.6 & 380 & 73 & 10 & 470 \\
\hline 71 & $07-26-68$ & 8.4 & -- & .4 & 47 & 0 & 16 & 1.7 & 1.7 & 6.8 & 23 & .5 & 69 \\
\hline 72 & $08-07-68$ & 8.1 & -- & 9.8 & 330 & 0 & 130 & 2.2 & 11 & 650 & 80 & 16 & 780 \\
\hline 73 & $08-06-68$ & 9.7 & -- & .4 & 10 & 0 & 2.8 & .70 & 5.3 & 570 & 99 & 82 & 1,370 \\
\hline 74 & $08-06-68$ & 6.2 & -- & 421 & 34 & 0 & 9.6 & 2.4 & 4.4 & 180 & 91 & 14 & 420 \\
\hline 75 & $08-08-68$ & 7.8 & -- & 2.8 & 65 & 0 & 20 & 3.6 & 5.9 & 16 & 33 & .9 & 110 \\
\hline 76 & $08-28-79$ & 8.7 & -- & .6 & 6 & 0 & 2.1 & .20 & 1.1 & 95 & 96 & 18 & 180 \\
\hline 77 & $08-06-68$ & 8.0 & -- & 2.4 & 120 & 0 & 37 & 6.3 & 4.9 & 6.2 & 10 & .3 & 150 \\
\hline 78 & $08-06-68$ & 7.5 & -- & 4.9 & 82 & 2 & 24 & 5.3 & 4.4 & 5.3 & 12 & .3 & 97 \\
\hline 79 & $08-06-68$ & 9.1 & -- & .1 & 10 & 0 & 2.4 & 1.0 & 5.5 & 30 & 79 & 4 & 95 \\
\hline 80 & $08-06-68$ & 8.7 & -- & .8 & 54 & 0 & 17 & 2.7 & 18 & 84 & 70 & 5 & 260 \\
\hline 81 & $09-06-68$ & 7.8 & -- & 3.3 & 130 & 26 & 48 & 3.2 & 5.8 & 10 & 13 & .4 & 130 \\
\hline 82 & $09-06-68$ & 7.7 & -- & 4.1 & 100 & 0 & 35 & 3.9 & 7.3 & 14 & 21 & .6 & 130 \\
\hline 83 & $08-06-68$ & 8.5 & -- & 4.9 & 38 & 0 & 12 & 1.9 & 130 & 380 & 80 & 28 & 980 \\
\hline 84 & $07-31-80$ & 8.8 & -- & .3 & 8 & 0 & 2.8 & .20 & 2.1 & 62 & 93 & 10 & 110 \\
\hline 85 & $08-09-68$ & 9.1 & -- & .1 & 9 & 0 & 3.6 & .00 & 1.8 & 76 & 94 & 12 & 84 \\
\hline 86 & $03-25-81$ & 6.5 & 7.4 & 67 & 100 & 0 & 33 & 5.3 & 6.8 & 17 & 25 & .8 & -- \\
\hline 87 & $08-23-78$ & 8.6 & -- & .3 & 37 & 0 & 12 & 1.6 & 3.7 & 14 & 42 & 1 & -- \\
\hline 88 & $05-08-80$ & 7.7 & -- & 7.7 & 300 & 96 & 69 & 30 & 9.1 & 33 & 19 & .9 & -- \\
\hline 89 & $07-3 i-80$ & 7.3 & -- & 22 & 270 & 41 & 87 & 13 & 8.9 & 47 & 27 & 1 & 280 \\
\hline 90 & $05-08-80$ & 7.3 & -- & 13 & 120 & 0 & 38 & 5.0 & 18 & 31 & 33 & 1 & -- \\
\hline 91 & $08-29-79$ & 6.7 & -- & 68 & 170 & 0 & 48 & 11 & 3.6 & 35 & 31 & 1 & 220 \\
\hline 92 & $10-21-75$ & 6.4 & -- & 645 & 230 & 0 & 68 & 15 & 47 & 460 & 77 & 14 & 1,020 \\
\hline 93 & $01-27-76$ & 6.5 & -- & 513 & 230 & 0 & 66 & 15 & 46 & 450 & 77 & 14 & 1,020 \\
\hline 94 & $04-21-76$ & 6.4 & -- & 652 & 230 & 0 & 68 & 15 & 46 & 430 & 76 & 13 & 1,030 \\
\hline 95 & $08-13-75$ & 6.8 & -- & 291 & 230 & 0 & 68 & 14 & 52 & 470 & 78 & 14 & 1,030 \\
\hline 96 & $10-21-75$ & 7.0 & -- & 165 & 210 & 0 & 61 & 15 & 51 & 480 & 79 & 15 & 1,040 \\
\hline 97 & $01-27-76$ & 7.0 & -- & 160 & 210 & 0 & 60 & 14 & 48 & 460 & 79 & 14 & 1,010 \\
\hline 98 & $04-18-76$ & 6.7 & -- & 323 & 230 & 0 & 66 & 15 & 48 & 490 & 79 & 15 & 1,020 \\
\hline 99 & $07-18-68$ & 8.7 & -- & .8 & 7 & 0 & 1.1 & 1.0 & 2.3 & 98 & 95 & 16 & 240 \\
\hline 100 & $08-20-76$ & 8.6 & -- & .4 & 10 & 0 & 4.0 & .10 & .50 & 42 & 89 & 6 & 110 \\
\hline
\end{tabular}


Table 4.--Water-quality information from selected wells and springs in the San Luis basin in Colorado and New Mexico--Continued

\begin{tabular}{|c|c|c|c|c|c|c|c|c|c|c|c|c|c|}
\hline $\begin{array}{l}\text { Site } \\
\text { obser- } \\
\text { vation } \\
\text { number }\end{array}$ & $\begin{array}{c}\text { Date } \\
\text { of } \\
\text { sample } \\
\text { (mo/d/yr) }\end{array}$ & $\begin{array}{c}\mathrm{pH}, \\
\text { field } \\
\text { (stand- } \\
\text { ard } \\
\text { units) }\end{array}$ & $\begin{array}{l}\text { pH, } \\
\text { labor- } \\
\text { atory } \\
\text { (stand- } \\
\text { ard } \\
\text { units) }\end{array}$ & $\begin{array}{c}\text { Carbon } \\
\text { diox- } \\
\text { ide, } \\
\text { dis- } \\
\text { solved } \\
(\mathrm{mg} / \mathrm{L} \\
\left.\text { as } \mathrm{CO}_{2}\right)\end{array}$ & $\begin{array}{l}\text { Hard- } \\
\text { ness } \\
\text { (mg/L } \\
\text { as } \\
\mathrm{CaCO}_{3} \text { ) }\end{array}$ & $\begin{array}{l}\text { Hard- } \\
\text { ness, } \\
\text { noncar- } \\
\text { bonate } \\
(\mathrm{mg} / \mathrm{L} \\
\text { as } \\
\mathrm{CaCO}_{3} \text { ) }\end{array}$ & $\begin{array}{l}\text { Cal- } \\
\text { cium, } \\
\text { dis- } \\
\text { solved } \\
\text { (mg/L } \\
\text { as } \mathrm{Ca} \text { ) }\end{array}$ & $\begin{array}{l}\text { Magne- } \\
\text { sium, } \\
\text { dis- } \\
\text { solved } \\
\text { (mg/L } \\
\text { as } \mathrm{Mg} \text { ) }\end{array}$ & $\begin{array}{l}\text { Potas- } \\
\text { sium, } \\
\text { dis- } \\
\text { solved } \\
\text { (mg/L } \\
\text { as K) }\end{array}$ & $\begin{array}{l}\text { Sodium, } \\
\text { dis- } \\
\text { solved } \\
\text { (mg/L } \\
\text { as } \mathrm{Na} \text { ) }\end{array}$ & $\begin{array}{l}\text { Per- } \\
\text { cent } \\
\text { so- } \\
\text { dium }\end{array}$ & $\begin{array}{l}\text { Sodium } \\
\text { adsorp- } \\
\text { tion } \\
\text { ratio }\end{array}$ & $\begin{array}{c}\text { Bicar- } \\
\text { bonate } \\
\text { (mg/L } \\
\text { as } \\
\left.\mathrm{HcO}_{3}\right)\end{array}$ \\
\hline 101 & $08-23-78$ & 8.5 & -- & .4 & 37 & 0 & 11 & 2.4 & 4.3 & 15 & 43 & 1 & -- \\
\hline 102 & $09-06-68$ & 7.9 & -- & 6.4 & 160 & 0 & 46 & 11 & 8.2 & 89 & 53 & 3 & 320 \\
\hline 103 & $07-11-68$ & 8.2 & -- & 1.1 & 34 & 0 & 12 & 1.0 & 5.0 & 33 & 64 & 3 & 110 \\
\hline 104 & $08-23-78$ & 6.6 & -- & 136 & 110 & 0 & 30 & 7.6 & 8.8 & 120 & 69 & 5 & -- \\
\hline 105 & $09-06-68$ & 7.5 & -- & 6.5 & 44 & 0 & 11 & 4.1 & 9.1 & 55 & 68 & 4 & 130 \\
\hline 106 & $08-23-78$ & 8.1 & -- & 1.1 & 39 & 0 & 12 & 2.3 & 4.5 & 20 & 49 & 1 & -- \\
\hline 107 & $05-08-80$ & 7.6 & -- & 17 & 250 & 0 & 77 & 14 & 12 & 190 & 61 & 5 & -- \\
\hline 108 & $03-25-81$ & 7.3 & 7.7 & 32 & 260 & 0 & 83 & 14 & 11 & 160 & 56 & 4 & -- \\
\hline 109 & $08-01-80$ & 7.6 & -- & 51 & 140 & 0 & 29 & 16 & 16 & 450 & 86 & 17 & 1,280 \\
\hline 110 & $08-23-78$ & 8.2 & -- & 2.4 & 37 & 0 & 10 & 2.8 & 6.1 & 110 & 84 & 8 & -- \\
\hline 111 & $08-23-78$ & 8.1 & -- & 1.4 & 51 & 0 & 15 & 3.3 & 5.8 & 18 & 40 & 1 & -- \\
\hline 112 & $09-12-68$ & 8.2 & -- & .7 & 45 & 0 & 14 & 2.4 & 4.2 & 14 & 38 & .9 & 67 \\
\hline 113 & $05-08-80$ & 7.4 & -- & 15 & 340 & 139 & 96 & 24 & 11 & 47 & 22 & 1 & -- \\
\hline 114 & $12-17-68$ & 8.2 & -- & 10 & 24 & 0 & 6.4 & 1.9 & 11 & 370 & 96 & 34 & 1,030 \\
\hline 115 & $09-06-68$ & 8.1 & -- & 3.7 & 28 & 0 & 6.4 & 2.9 & 2.7 & 110 & 88 & 9 & 290 \\
\hline 116 & $09-06-68$ & 7.0 & -- & 44 & 390 & 161 & 130 & 16 & 9.2 & 52 & 22 & 1 & 280 \\
\hline 117 & $07-30-80$ & 6.7 & -- & 59 & 150 & 0 & 48 & 6.9 & 1.4 & 5.3 & 7 & .2 & 190 \\
\hline 118 & $08-06-68$ & 8.0 & -- & 1.6 & 25 & 0 & 10 & .00 & .70 & 41 & 78 & 4 & 100 \\
\hline 119 & $07-31-80$ & 6.9 & -- & 44 & 140 & 0 & 43 & 7.6 & 6.6 & 43 & 39 & 2 & -- \\
\hline 120 & $07-30-80$ & 7.5 & -- & 4.1 & 63 & 0 & 19 & 3.8 & 1.4 & 5.6 & 16 & .3 & 82 \\
\hline 121 & $07-29-80$ & 7.4 & -- & 10 & 1,200 & 1,070 & 300 & 110 & 15 & 230 & 29 & 3 & 160 \\
\hline 122 & $09-06-68$ & 7.5 & -- & 9.0 & 180 & 33 & 58 & 8.8 & 4.4 & 21 & 20 & .7 & 180 \\
\hline 123 & $08-21-68$ & 7.8 & -- & 3.3 & 100 & 0 & 35 & 4.1 & 1.3 & 16 & 25 & .7 & 130 \\
\hline 124 & $10-09-75$ & 6.5 & -- & 178 & 200 & 0 & 59 & 13 & 14 & 150 & 60 & 5 & 350 \\
\hline 125 & $01-25-76$ & 6.5 & -- & 177 & 190 & 0 & 56 & 13 & 14 & 140 & 59 & 5 & 350 \\
\hline 126 & $04-20-76$ & 7.3 & -- & 28 & 200 & 0 & 58 & 13 & 14 & 140 & 58 & 4 & 350 \\
\hline 127 & $10-09-75$ & 6.5 & -- & 168 & 200 & $0^{\circ}$ & 60 & 13 & 14 & 140 & 58 & 4 & 340 \\
\hline 128 & $01-25-76$ & 7.0 & -- & 56 & 200 & 0 & 57 & 13 & 15 & 140 & 59 & 5 & 350 \\
\hline 129 & $04-20-76$ & 6.8 & -- & 89 & 200 & 0 & 59 & 13 & 14 & 140 & 58 & 4 & 350 \\
\hline 130 & $07-29-80$ & 7.4 & -- & 8.5 & 100 & 0 & 25 & 9.9 & 1.3 & 17 & 26 & .8 & 130 \\
\hline 131 & $10-23-75$ & 6.7 & -- & 37 & 70 & 0 & 21 & 4.2 & 1.6 & 80 & 71 & 4 & 120 \\
\hline
\end{tabular}


Table 4.--Water-quality information from selected wells and springs in the San Luis basin in Colorado and New Mexico--Continued

\begin{tabular}{|c|c|c|c|c|c|c|c|c|c|c|c|c|c|}
\hline $\begin{array}{l}\text { Site } \\
\text { obser- } \\
\text { vation } \\
\text { number }\end{array}$ & $\begin{array}{c}\text { Date } \\
\text { of } \\
\text { sample } \\
\text { (mo/d/yr) }\end{array}$ & $\begin{array}{c}\text { Car- } \\
\text { bon- } \\
\text { ate } \\
(\mathrm{mg} / \mathrm{L} \\
\text { as } \\
\left.\mathrm{CO}_{3}\right)\end{array}$ & $\begin{array}{c}\text { Alka- } \\
\text { linity, } \\
\text { field } \\
(\mathrm{fg} / \mathrm{L} \\
\text { as } \\
\left.\mathrm{CaCO}_{3}\right)\end{array}$ & $\begin{array}{l}\text { Alka- } \\
\text { linity, } \\
\text { labor- } \\
\text { atory } \\
(\mathrm{mg} / \mathrm{L} \\
\left.\mathrm{CaCO}_{3}\right)\end{array}$ & $\begin{array}{l}\text { Chlo- } \\
\text { ride, } \\
\text { dis- } \\
\text { solved } \\
\text { (mg/L } \\
\text { as Cl) }\end{array}$ & $\begin{array}{l}\text { Fluo- } \\
\text { ride, } \\
\text { dis- } \\
\text { solved } \\
\text { (mg/L } \\
\text { as F) }\end{array}$ & $\begin{array}{c}\text { Sul- } \\
\text { Sul- } \\
\text { fate, } \\
\text { dis- } \\
\text { solved } \\
(\mathrm{mg} / \mathrm{L} \\
\left.\text { as } \mathrm{SO}_{4}\right)\end{array}$ & $\begin{array}{l}\text { Sil- } \\
\text { ica, } \\
\text { dis- } \\
\text { solved } \\
\text { (mg/L } \\
\text { as } \\
\mathrm{SIO}_{2} \text { ) }\end{array}$ & $\begin{array}{l}\text { Solids, } \\
\text { sum of } \\
\text { con- } \\
\text { stit- } \\
\text { uents, } \\
\text { dis- } \\
\text { solved } \\
(\mathrm{mg} / \mathrm{L})\end{array}$ & $\begin{array}{l}\text { Nitro- } \\
\text { gen } \\
\text { ni- } \\
\text { trate, } \\
\text { dis- } \\
\text { solved } \\
\text { (mg/L } \\
\text { as } N \text { ) }\end{array}$ & $\begin{array}{l}\text { Nitro- } \\
\text { gen } \\
\text { ni- } \\
\text { trite, } \\
\text { dis- } \\
\text { solved } \\
\text { (mg/L } \\
\text { as N) }\end{array}$ & $\begin{array}{l}\text { Nitro- } \\
\text { gen } \\
\text { nitrite } \\
\text { plus } \\
\text { nitrate, } \\
\text { dis- } \\
\text { solved } \\
\text { (mg/L) }\end{array}$ & $\begin{array}{l}\text { Nitro- } \\
\text { gen } \\
\text { ammo- } \\
\text { nia, } \\
\text { dis- } \\
\text { solved } \\
\text { (mg/L } \\
\text { as N) }\end{array}$ \\
\hline 1 & $03-08-83$ & -- & 180 & 186 & 4.2 & 1.8 & 29 & 24 & 270 & 0.690 & -- & 0.690 & -- \\
\hline 2 & $11-17-81$ & -- & -- & 280 & 6.9 & 1.4 & 38 & 16 & 370 & -- & -- & -- & -- \\
\hline 3 & $07-23-76$ & -- & 115 & -- & 4.0 & .37 & 74 & 30 & 260 & -- & -- & -- & -- \\
\hline 4 & $09-06-79$ & -- & 230 & -- & 5.1 & .20 & 33 & 18 & 300 & 1.10 & -- & 1.10 & -- \\
\hline 5 & $07-22-76$ & -- & 164 & -- & 58 & 2.9 & 150 & 67 & 560 & -- & -- & -- & -- \\
\hline 6 & $08-19-82$ & 0.00 & 82 & 83 & 2.9 & .30 & 23 & 29 & 150 & .510 & -- & .510 & -- \\
\hline 7 & $08-19-82$ & .00 & 75 & 74 & 7.1 & 1.1 & 20 & 33 & 150 & .620 & -- & .620 & -- \\
\hline 8 & $08-20-82$ & .00 & 75 & 75 & 6.8 & 1.1 & 22 & 33 & 160 & .680 & -- & .680 & -- \\
\hline 9 & $09-06-79$ & -- & 82 & -- & 4.4 & 1.3 & 19 & 34 & 150 & .440 & -- & .440 & -- \\
\hline 10 & $03-09-66$ & .00 & 139 & -- & 4.8 & .70 & 65 & 17 & 260 & .520 & -- & -- & -- \\
\hline 11 & $06-01-81$ & -- & -- & 77 & 1.4 & .20 & 2.6 & 48 & 130 & .700 & -- & .700 & -- \\
\hline 12 & $08-13-80$ & -- & 120 & -- & 2.3 & .40 & 5.8 & 36 & 160 & .650 & -- & .650 & -- \\
\hline 13 & $06-26-68$ & .00 & 66 & -- & 7.0 & .60 & 12 & 20 & 130 & 3.40 & -- & -- & -- \\
\hline 14 & $06-04-82$ & -- & -- & 88 & 2.1 & .20 & 5.0 & 38 & 130 & 1.10 & -- & 1.10 & -- \\
\hline 15 & $06-04-82$ & -- & -- & 91 & 2.4 & .20 & 5.0 & 39 & 140 & 1.30 & -- & 1.30 & -- \\
\hline 16 & $06-04-82$ & -- & -- & 76 & 2.0 & .20 & $<5.0$ & 37 & -- & .700 & -- & .700 & -- \\
\hline 17 & $06-04-82$ & -- & -- & 113 & 2.3 & .90 & 6.0 & 47 & 170 & 2.00 & -- & 2.00 & -- \\
\hline 18 & $08-29-79$ & -- & 100 & -- & 2.5 & .20 & 12 & 35 & 160 & 2.00 & -- & 2.00 & -- \\
\hline 19 & $09-09-68$ & .00 & 117 & -- & .70 & .50 & 3.6 & 32 & 160 & .110 & -- & -- & -- \\
\hline 20 & $09-10-68$ & .00 & 82 & -- & .80 & .80 & 16 & 11 & 120 & .610 & -- & -- & -- \\
\hline 21 & $06-03-82$ & -- & -- & 72 & .70 & .20 & $<5.0$ & 37 & -- & .370 & -- & .370 & -- \\
\hline 22 & $06-02-82$ & -- & -- & 80 & 1.1 & .30 & $<5.0$ & 39 & -- & .260 & -- & .260 & -- \\
\hline 23 & $09-10-68$ & .00 & 172 & -- & 3.1 & .70 & 36 & 28 & 260 & .160 & -- & -- & -- \\
\hline 24 & $08-08-68$ & .00 & 75 & -- & .90 & .50 & 2.4 & 30 & 110 & .020 & -- & -- & -- \\
\hline 25 & $05-14-68$ & .00 & 156 & -- & 8.8 & .80 & 28 & 19 & 230 & -- & -- & -- & -- \\
\hline 26 & $09-09-68$ & .00 & 230 & -- & 17 & 1.1 & 80 & 55 & 440 & .090 & -- & -- & -- \\
\hline 27 & $04-19-76$ & .00 & 62 & -- & 1.1 & .20 & 32 & 53 & 160 & .290 & -- & .290 & -- \\
\hline 28 & $06-07-68$ & .00 & 98 & -- & 2.9 & .60 & 11 & 31 & 150 & .290 & -- & -- & -- \\
\hline 29 & $08-20-68$ & .00 & 131 & -- & 31 & 2.1 & 32 & 58 & 300 & .070 & -- & -- & -- \\
\hline 30 & $07-23-80$ & .00 & 130 & -- & 24 & 2.1 & 36 & 58 & 290 & .770 & -- & .770 & -- \\
\hline 31 & $04-19-76$ & .00 & 77 & -- & 2.3 & .70 & 29 & 65 & 190 & .330 & -- & .330 & -- \\
\hline 32 & $08-19-68$ & .00 & 115 & -- & 2.5 & 2.8 & 16 & 77 & 230 & .090 & -- & -- & -- \\
\hline 33 & $06-18-68$ & .00 & 164 & -- & 4.1 & .80 & 21 & 39 & 250 & .900 & -- & -- & -- \\
\hline 34 & $06-26-68$ & .00 & 107 & -- & 2.2 & .40 & 8.8 & 16 & 150 & 1.10 & -- & -- & -- \\
\hline 35 & $07-22-80$ & .00 & 150 & -- & 4.5 & .60 & 15 & 42 & 220 & .710 & -- & .710 & -- \\
\hline 36 & $05-07-68$ & .00 & 90 & -- & 3.1 & .40 & 19 & 51 & 180 & .230 & -- & -- & -- \\
\hline 37 & $09-10-68$ & .00 & 148 & -- & 1.7 & .80 & 20 & 20 & 210 & 2.00 & -- & -- & -- \\
\hline 38 & $07-22-80$ & .00 & 140 & -- & 1.9 & .50 & 11 & 22 & 170 & 1.20 & -- & 1.20 & -- \\
\hline 39 & $07-18-68$ & .00 & 98 & -- & 5.5 & .80 & 18 & 70 & 210 & .200 & -- & -- & -- \\
\hline 40 & $09-10-68$ & .00 & 123 & -- & 14 & .60 & 62 & 36 & 270 & .110 & -- & -- & -- \\
\hline 41 & $08-23-68$ & 6 & 190 & -- & 18 & 9.5 & 29 & 98 & 400 & .020 & -- & -- & -- \\
\hline 42 & $06-07-68$ & .00 & 79 & -- & 4.2 & .40 & 11 & 24 & 130 & 1.00 & -- & -- & -- \\
\hline 43 & $07-19-68$ & .00 & 82 & -- & 1.3 & .30 & 4.6 & 67 & 160 & .160 & -- & -- & -- \\
\hline 44 & $08-05-68$ & .00 & 164 & -- & 1.1 & 1.1 & 22 & 20 & 230 & .590 & -- & -- & -- \\
\hline 45 & $08-05-68$ & .00 & 74 & -- & 1.6 & .80 & 6.8 & 20 & 110 & .140 & -- & -- & -- \\
\hline 46 & $08-05-68$ & .00 & 90 & -- & 2.2 & .30 & 15 & 37 & 150 & .230 & -- & -- & -- \\
\hline 47 & $08-09-68$ & .00 & 287 & -- & 52 & 3.6 & 92 & 43 & 580 & .160 & -- & -- & -- \\
\hline 48 & $08-12-75$ & .00 & 124 & -- & 6.4 & 4.2 & 29 & 110 & 310 & -- & -- & $<.100$ & -- \\
\hline 49 & $07-31-80$ & -- & 250 & -- & 30 & .50 & 53 & 51 & 440 & .020 & -- & .020 & -- \\
\hline 50 & $08-05-68$ & .00 & 312 & -- & 44 & .70 & 74 & 36 & 530 & .090 & -- & -- & -- \\
\hline
\end{tabular}


Table 4.--Water-quality information from selected wells and springs in the San Luis basin in Colorado and New Mexico--Continued

\begin{tabular}{|c|c|c|c|c|c|c|c|c|c|c|c|c|c|}
\hline $\begin{array}{l}\text { Site } \\
\text { obser- } \\
\text { vation } \\
\text { number }\end{array}$ & $\begin{array}{c}\text { Date } \\
\text { of } \\
\text { sample } \\
\text { (mo/d/yr) }\end{array}$ & $\begin{array}{c}\text { Car- } \\
\text { bon- } \\
\text { ate } \\
(\mathrm{mg} / \mathrm{L} \\
\text { as } \\
\left.\mathrm{CO}_{3}\right)\end{array}$ & $\begin{array}{c}\text { Alka- } \\
\text { linity, } \\
\text { field } \\
(\mathrm{fg} / \mathrm{L} \\
\text { as } \\
\left.\mathrm{CaCO}_{3}\right)\end{array}$ & $\begin{array}{l}\text { Alka- } \\
\text { linity, } \\
\text { labor- } \\
\text { atory } \\
(\mathrm{mg} / \mathrm{L} \\
\left.\mathrm{CaCO}_{3}\right)\end{array}$ & $\begin{array}{l}\text { Chlo- } \\
\text { ride, } \\
\text { dis- } \\
\text { solved } \\
\text { (mg/L } \\
\text { as Cl) }\end{array}$ & $\begin{array}{l}\text { Fluo- } \\
\text { ride, } \\
\text { dis- } \\
\text { solved } \\
(\mathrm{mg} / \mathrm{L} \\
\text { as F) }\end{array}$ & $\begin{array}{l}\text { Sul- } \\
\text { Sul- } \\
\text { fate, } \\
\text { dis- } \\
\text { solved } \\
(\mathrm{mg} / \mathrm{L} \\
\left.\text { as } \mathrm{SO}_{4}\right)\end{array}$ & $\begin{array}{l}\text { Sil- } \\
\text { ica, } \\
\text { dis- } \\
\text { solved } \\
\text { (mg/L } \\
\text { as } \\
\mathrm{SIO}_{2} \text { ) }\end{array}$ & $\begin{array}{l}\text { Solids, } \\
\text { sum of } \\
\text { con- } \\
\text { stit- } \\
\text { uents, } \\
\text { dis- } \\
\text { solved } \\
\text { (mg/L) }\end{array}$ & $\begin{array}{l}\text { Nitro- } \\
\text { gen } \\
\text { ni- } \\
\text { trate, } \\
\text { dis- } \\
\text { solved } \\
\text { (mg/L } \\
\text { as } \mathrm{N} \text { ) }\end{array}$ & $\begin{array}{l}\text { Nitro- } \\
\text { gen } \\
\text { ni- } \\
\text { trite, } \\
\text { dis- } \\
\text { solved } \\
\text { (mg/L } \\
\text { as N) }\end{array}$ & $\begin{array}{l}\text { Nitro- } \\
\text { gen } \\
\text { nitrite } \\
\text { plus } \\
\text { nitrate, } \\
\text { dis- } \\
\text { solved } \\
\text { (mg/L) }\end{array}$ & $\begin{array}{l}\text { Nitro- } \\
\text { gen } \\
\text { ammo- } \\
\text { nia, } \\
\text { dis- } \\
\text { solved } \\
\text { (mg/L } \\
\text { as N) }\end{array}$ \\
\hline $\begin{array}{l}51 \\
52 \\
53 \\
54 \\
55\end{array}$ & $\begin{array}{l}08-05-68 \\
08-05-68 \\
08-09-68 \\
08-05-68 \\
08-22-78\end{array}$ & $\begin{array}{r}0.00 \\
.00 \\
.00 \\
.00 \\
.-\end{array}$ & $\begin{array}{r}58 \\
90 \\
271 \\
139 \\
62\end{array}$ & $\begin{array}{l}-- \\
-- \\
-- \\
--\end{array}$ & $\begin{array}{c}1.3 \\
4.8 \\
65 \\
210 \\
1.3\end{array}$ & $\begin{array}{l}.40 \\
.40 \\
.60 \\
1.3 \\
.20\end{array}$ & $\begin{array}{c}7.2 \\
13 \\
110 \\
530 \\
7.3\end{array}$ & $\begin{array}{l}29 \\
27 \\
51 \\
40 \\
19\end{array}$ & $\begin{array}{r}100 \\
150 \\
600 \\
1,300 \\
94\end{array}$ & $\begin{array}{r}0.050 \\
.160 \\
.140 \\
.160 \\
.020\end{array}$ & $\begin{array}{c}- \\
-- \\
-- \\
-- \\
<0.010\end{array}$ & $\begin{array}{c}-- \\
-- \\
-- \\
-- \\
0.020\end{array}$ & $\begin{array}{l}-- \\
-- \\
-- \\
-- \\
0.010\end{array}$ \\
\hline $\begin{array}{l}56 \\
57 \\
58 \\
59 \\
60\end{array}$ & $\begin{array}{l}07-18-68 \\
08-07-68 \\
08-07-68 \\
08-09-68 \\
08-07-68\end{array}$ & $\begin{array}{l}.00 \\
.00 \\
8^{5} \\
.00\end{array}$ & $\begin{array}{r}140 \\
689 \\
56 \\
366 \\
344\end{array}$ & $\begin{array}{l}-- \\
-- \\
-- \\
--\end{array}$ & ${ }_{420^{.70}}^{.50}$ & $\begin{array}{l}.90 \\
.40 \\
.30 \\
.50 \\
1.4\end{array}$ & $\begin{array}{c}5.8 \\
470 \\
6.0 \\
120 \\
770\end{array}$ & $\begin{array}{l}67 \\
43 \\
24 \\
43 \\
27\end{array}$ & $\begin{array}{r}230 \\
2,100 \\
90 \\
710 \\
2,200\end{array}$ & $\begin{array}{l}.230 \\
.110 \\
.070 \\
.090 \\
.290\end{array}$ & $\begin{array}{l}-- \\
-- \\
-- \\
-- \\
--\end{array}$ & $\begin{array}{l}-- \\
-- \\
-- \\
--\end{array}$ & $\begin{array}{l}-- \\
-- \\
-- \\
--\end{array}$ \\
\hline $\begin{array}{l}61 \\
62 \\
63 \\
64 \\
65\end{array}$ & $\begin{array}{l}09-09-68 \\
08-05-68 \\
07-03-68 \\
08-08-68 \\
08-07-68\end{array}$ & $10_{15^{.00}}^{.00}$ & $\begin{array}{r}279 \\
65 \\
140 \\
632 \\
616\end{array}$ & $\begin{array}{l}-- \\
-- \\
-- \\
--\end{array}$ & $\begin{array}{rl}2.8 & .90 \\
1.1 \\
3,200 \\
17\end{array}$ & $\begin{array}{l}.80 \\
.20 \\
5.0 \\
.70 \\
1.6\end{array}$ & $\begin{array}{r}52 \\
5.0 \\
15 \\
3,000 \\
3.0\end{array}$ & $\begin{array}{l}56 \\
21 \\
93 \\
27 \\
40\end{array}$ & $\begin{array}{r}430 \\
95 \\
280 \\
10,000 \\
730\end{array}$ & $\begin{array}{l}.090 \\
.050 \\
.020 \\
.160 \\
.050\end{array}$ & $\begin{array}{l}-- \\
-- \\
-- \\
--\end{array}$ & $\begin{array}{l}-- \\
-- \\
-- \\
--\end{array}$ & $\begin{array}{l}-- \\
-- \\
-- \\
--\end{array}$ \\
\hline $\begin{array}{l}66 \\
67 \\
68 \\
69 \\
70\end{array}$ & $\begin{array}{l}11-01-68 \\
11-01-68 \\
11-01-68 \\
08-08-68 \\
08-07-68\end{array}$ & $\begin{array}{r}59 \\
.00 \\
.00 \\
49 \\
.00\end{array}$ & $\begin{array}{r}5,830 \\
5,860 \\
5,910 \\
959 \\
385\end{array}$ & $\begin{array}{l}-- \\
-- \\
-- \\
--\end{array}$ & $\begin{array}{r}5,200 \\
5,200 \\
5,200 \\
97 \\
160\end{array}$ & $\begin{array}{l}8.2 \\
7.1 \\
6.1 \\
3.3 \\
1.3\end{array}$ & $\begin{array}{r}12,000 \\
12,000 \\
11,000 \\
200 \\
490\end{array}$ & $\begin{array}{l}34 \\
34 \\
36 \\
28 \\
43\end{array}$ & $\begin{array}{r}32,000 \\
32,000 \\
31,000 \\
1,500 \\
1,400\end{array}$ & $\begin{array}{l}-- \\
-- \\
-- \\
.770 \\
.050\end{array}$ & $\begin{array}{l}-- \\
-- \\
-- \\
--\end{array}$ & $\begin{array}{l}-- \\
-- \\
-- \\
--\end{array}$ & $\begin{array}{l}-- \\
-- \\
-- \\
--\end{array}$ \\
\hline $\begin{array}{l}71 \\
72 \\
73 \\
74 \\
75\end{array}$ & $\begin{array}{l}07-26-68 \\
08-07-68 \\
08-06-68 \\
08-06-68 \\
08-08-68\end{array}$ & $\begin{array}{r}3 \\
79^{.00} \\
.00 \\
.00\end{array}$ & $\begin{array}{r}62 \\
640 \\
1,260 \\
344 \\
90\end{array}$ & $\begin{array}{l}-- \\
-- \\
-- \\
--\end{array}$ & $\begin{array}{c}320^{.50} \\
63 \\
10 \\
1.3\end{array}$ & $\begin{array}{l}.20 \\
4.0 \\
6.6 \\
4.2 \\
.30\end{array}$ & $\begin{array}{c}4.2 \\
660^{-6} \\
69^{.6} \\
9.6\end{array}$ & $\begin{array}{l}39 \\
43 \\
32 \\
36 \\
45\end{array}$ & $\begin{array}{r}110 \\
2,200 \\
1,500 \\
530 \\
160\end{array}$ & $\begin{array}{l}.050 \\
.050 \\
.380 \\
.930 \\
.770\end{array}$ & $\begin{array}{l}-- \\
-- \\
-- \\
--\end{array}$ & $\begin{array}{l}-- \\
-- \\
-- \\
--\end{array}$ & $\begin{array}{l}-- \\
-- \\
-- \\
-- \\
--\end{array}$ \\
\hline $\begin{array}{l}76 \\
77 \\
78 \\
79 \\
80\end{array}$ & $\begin{array}{l}08-28-79 \\
08-06-68 \\
08-06-68 \\
08-06-68 \\
08-06-68\end{array}$ & $\begin{array}{r}12 \\
.00 \\
.00 \\
.00 \\
.00\end{array}$ & $\begin{array}{r}170 \\
123 \\
80 \\
78 \\
213\end{array}$ & $\begin{array}{l}-- \\
-- \\
-- \\
--\end{array}$ & $\begin{array}{l}5.0 \\
1.7 \\
1.1 \\
1.3 \\
9.8\end{array}$ & $\begin{array}{c}7.8 \\
.30 \\
.30 \\
.50 \\
1.4\end{array}$ & $\begin{array}{l}22 \\
8.2 \\
7.2 \\
1.4 \\
36\end{array}$ & $\begin{array}{l}78 \\
42 \\
38 \\
26 \\
27\end{array}$ & $\begin{array}{l}330 \\
180 \\
130 \\
120 \\
320\end{array}$ & $\begin{array}{l}.040 \\
.070 \\
.290 \\
.110 \\
.070\end{array}$ & $\begin{array}{l}-- \\
-- \\
-- \\
--\end{array}$ & $\begin{array}{c}0.040 \\
-- \\
-- \\
-- \\
--\end{array}$ & $\begin{array}{l}-- \\
-- \\
-- \\
--\end{array}$ \\
\hline $\begin{array}{l}81 \\
82 \\
83 \\
84 \\
85\end{array}$ & $\begin{array}{l}09-06-68 \\
09-06-68 \\
08-06-68 \\
07-31-80 \\
08-09-68\end{array}$ & $30_{16}^{.00}$ & $\begin{array}{r}107 \\
107 \\
854 \\
84 \\
96\end{array}$ & $\begin{array}{l}-- \\
-- \\
-- \\
--\end{array}$ & $\begin{array}{c}5.2 \\
1.4 \\
55 \\
7.8 \\
13\end{array}$ & $\begin{array}{l}.20 \\
.30 \\
4.8 \\
2.5 \\
5.3\end{array}$ & $\begin{array}{r}28 \\
18 \\
120 \\
36 \\
52\end{array}$ & $\begin{array}{l}31 \\
35 \\
23 \\
70 \\
54\end{array}$ & $\begin{array}{r}220 \\
190 \\
1,300 \\
240 \\
280\end{array}$ & $\begin{array}{l}5.20 \\
3.20 \\
.660 \\
.100 \\
.070\end{array}$ & $\begin{array}{l}-- \\
-- \\
\cdots \\
--\end{array}$ & $\begin{array}{l}-- \\
-- \\
-- \\
100 \\
--\end{array}$ & $\begin{array}{l}-- \\
-- \\
-- \\
--\end{array}$ \\
\hline $\begin{array}{l}86 \\
87 \\
88 \\
89 \\
90\end{array}$ & $\begin{array}{l}03-25-81 \\
08-23-78 \\
05-08-80 \\
07-31-80 \\
05-08-80\end{array}$ & $\begin{array}{l}- \\
-- \\
-. \\
.00 \\
--\end{array}$ & $\begin{array}{r}-- \\
70 \\
200 \\
230 \\
130\end{array}$ & $\begin{array}{l}110 \\
-- \\
-- \\
-- \\
--\end{array}$ & $\begin{array}{c}2.4 \\
1.4 \\
26 \\
8.9 \\
11\end{array}$ & $\begin{array}{l}.20 \\
.20 \\
.30 \\
.10 \\
.20\end{array}$ & $\begin{array}{c}14 \\
5.7 \\
120 \\
86 \\
53\end{array}$ & $\begin{array}{l}43 \\
4.5 \\
48 \\
40 \\
40\end{array}$ & $\begin{array}{r}200 \\
86 \\
460 \\
430 \\
270\end{array}$ & $\begin{aligned} 2.90 \\
.010 \\
.600 \\
15.0 \\
.090\end{aligned}$ & $\begin{array}{l}.000 \\
.050 \\
-- \\
-- \\
--\end{array}$ & $\begin{array}{c}2.90 \\
.060 \\
.600 \\
15.0 \\
.090\end{array}$ & $\begin{array}{l}.000 \\
.160 \\
-- \\
-- \\
--\end{array}$ \\
\hline $\begin{array}{l}91 \\
92 \\
93 \\
94 \\
95\end{array}$ & $\begin{array}{l}08-29-79 \\
10-21-75 \\
01-27-76 \\
04-21-76 \\
08-13-75\end{array}$ & $\begin{array}{l}-. \\
.00 \\
.00 \\
.00 \\
.00\end{array}$ & $\begin{array}{l}180 \\
837 \\
837 \\
845 \\
845\end{array}$ & $\begin{array}{l}-- \\
-- \\
-- \\
--\end{array}$ & $\begin{array}{l}9.6 \\
200 \\
200 \\
190 \\
200\end{array}$ & $\begin{array}{l}.40 \\
6.3 \\
6.8 \\
8.5 \\
7.0\end{array}$ & $\begin{array}{r}49 \\
150 \\
160 \\
130 \\
160\end{array}$ & $\begin{array}{l}39 \\
68 \\
88 \\
72 \\
87\end{array}$ & $\begin{array}{r}300 \\
1,500 \\
1,500 \\
1,500 \\
1,600\end{array}$ & $\begin{array}{l}1.40 \\
.030 \\
.040 \\
.020 \\
.040\end{array}$ & $\begin{array}{l}-- \\
-- \\
-- \\
--\end{array}$ & $\begin{array}{l}1.40 \\
.030 \\
.040 \\
.020 \\
.040\end{array}$ & $\begin{array}{l}-- \\
-- \\
-- \\
--\end{array}$ \\
\hline $\begin{array}{r}96 \\
97 \\
98 \\
99 \\
100\end{array}$ & $\begin{array}{l}10-21-75 \\
01-27-76 \\
04-18-76 \\
07-18-68 \\
08-20-76\end{array}$ & $\begin{array}{l}.00 \\
.00 \\
14^{.00} \\
8\end{array}$ & $\begin{array}{l}853 \\
828 \\
837 \\
220 \\
104\end{array}$ & $\begin{array}{l}- \\
-- \\
-- \\
--\end{array}$ & $\begin{array}{r}200 \\
200 \\
200 \\
2.0 \\
3.3\end{array}$ & $\begin{array}{l}6.6 \\
6.7 \\
7.6 \\
3.2 \\
1.9\end{array}$ & $\begin{array}{c}170 \\
170 \\
200 \\
15 \\
3.0\end{array}$ & $\begin{array}{l}81 \\
90 \\
84 \\
76 \\
50\end{array}$ & $\begin{array}{r}1,600 \\
1,500 \\
1,600 \\
350 \\
180\end{array}$ & $\begin{array}{l}.010 \\
.010 \\
\ldots \\
.200 \\
\ldots\end{array}$ & $\begin{array}{l}-- \\
-- \\
-- \\
--\end{array}$ & $\begin{array}{r}.010 \\
.010 \\
<.100 \\
-- \\
.-\end{array}$ & $\begin{array}{l}-- \\
-- \\
-- \\
--\end{array}$ \\
\hline
\end{tabular}


Table 4.--Water-quality information from selected wells and springs in the San Luis bas in in Colorado and New Mexico--Continued

\begin{tabular}{|c|c|c|c|c|c|c|c|c|c|c|c|c|c|}
\hline $\begin{array}{l}\text { Site } \\
\text { obser- } \\
\text { vation } \\
\text { number }\end{array}$ & $\begin{array}{c}\text { Date } \\
\text { of } \\
\text { sample } \\
\text { (mo/d/yr) }\end{array}$ & $\begin{array}{c}\text { Car- } \\
\text { bon- } \\
\text { ate } \\
(\mathrm{mg} / \mathrm{L} \\
\text { as } \\
\left.\mathrm{CO}_{3}\right)\end{array}$ & $\begin{array}{c}\text { Alka- } \\
\text { linity, } \\
\text { field } \\
(\mathrm{fg} / \mathrm{L} \\
\text { as } \\
\left.\mathrm{CaCO}_{3}\right)\end{array}$ & $\begin{array}{l}\text { Alka- } \\
\text { linity, } \\
\text { labor- } \\
\text { atory } \\
(\mathrm{mg} / \mathrm{L} \\
\left.\mathrm{CaCO}_{3}\right)\end{array}$ & $\begin{array}{l}\text { Chlo- } \\
\text { ride, } \\
\text { dis- } \\
\text { solved } \\
\text { (mg/L } \\
\text { as Cl) }\end{array}$ & $\begin{array}{l}\text { Fluo- } \\
\text { ride, } \\
\text { dis- } \\
\text { solved } \\
(\mathrm{mg} / \mathrm{L} \\
\text { as F) }\end{array}$ & $\begin{array}{l}\text { Sul- } \\
\text { Sul- } \\
\text { fate, } \\
\text { dis- } \\
\text { solved } \\
\text { (mg/L } \\
\text { as } \mathrm{SO}_{4} \text { ) }\end{array}$ & $\begin{array}{l}\text { Sil- } \\
\text { ica, } \\
\text { dis- } \\
\text { solved } \\
\text { (mg/L } \\
\text { as } \\
\mathrm{SIO}_{2} \text { ) }\end{array}$ & $\begin{array}{l}\text { Solids, } \\
\text { sum of } \\
\text { con- } \\
\text { stit- } \\
\text { uents, } \\
\text { dis- } \\
\text { solved } \\
\text { (mg/L) }\end{array}$ & $\begin{array}{l}\text { Nitro- } \\
\text { gen } \\
\text { ni- } \\
\text { trate, } \\
\text { dis- } \\
\text { solved } \\
\text { (mg/L } \\
\text { as } N \text { ) }\end{array}$ & $\begin{array}{l}\text { Nitro- } \\
\text { gen } \\
\text { ni- } \\
\text { trite, } \\
\text { dis- } \\
\text { solved } \\
\text { (mg/L } \\
\text { as } N \text { ) }\end{array}$ & $\begin{array}{l}\text { Nitro- } \\
\text { gen } \\
\text { nitrite } \\
\text { plus } \\
\text { nitrate, } \\
\text { dis- } \\
\text { solved } \\
\text { (mg/L) }\end{array}$ & $\begin{array}{l}\text { Nitro- } \\
\text { gen } \\
\text { ammo- } \\
\text { nia, } \\
\text { dis- } \\
\text { solved } \\
\text { (mg/L } \\
\text { as N) }\end{array}$ \\
\hline 101 & $08-23-78$ & -- & 74 & -- & 1.7 & 0.80 & 1.7 & 50 & 140 & 0.010 & 0.010 & 0.020 & 2.30 \\
\hline 102 & $09-06-68$ & .00 & 262 & - & 28 & 1.0 & 61 & 50 & 450 & .090 & -- & -- & -- \\
\hline 103 & $07-11-68$ & .00 & 90 & -- & 1.3 & 1.1 & 14 & 61 & 180 & .160 & -- & -- & -- \\
\hline 104 & $08-23-78$ & -- & 280 & -- & 19 & 2.5 & 51 & 53 & 460 & .130 & .010 & .140 & .510 \\
\hline 105 & $09-06-68$ & .00 & 107 & -- & 16 & .90 & 36 & 44 & 250 & 2.30 & -- & -- & -- \\
\hline 106 & $08-23-78$ & -- & 72 & -- & 4.1 & .90 & 4.2 & 45 & 140 & .010 & .010 & .020 & 2.70 \\
\hline 107 & $05-08-80$ & -- & 340 & -- & 55 & .30 & 210 & 41 & 800 & 1.60 & -- & 1.60 & -- \\
\hline 108 & $03-25-81$ & -- & -- & 330 & 50 & .30 & 210 & 40 & 770 & 1.10 & .000 & 1.10 & .000 \\
\hline 109 & $08-01-80$ & .00 & 1,040 & -- & 65 & .40 & .9 & .1 & 1,200 & .090 & -- & .090 & -- \\
\hline 110 & $08-23-78$ & -- & 200 & -- & 57 & 1.6 & .9 & 33 & 340 & .000 & .010 & .010 & .920 \\
\hline 111 & $08-23-78$ & -- & 93 & -- & 2.7 & .20 & 5.3 & 19 & 130 & .020 & $<.010$ & .020 & .840 \\
\hline 112 & $09-12-68$ & .00 & 55 & -- & 1.8 & .80 & 15 & 64 & 150 & .140 & -- & -- & -- \\
\hline 113 & $05-08-80$ & -- & 200 & -- & 120 & .20 & 86 & 55 & 580 & .000 & -- & .000 & -- \\
\hline 114 & $12-17-68$ & .00 & 845 & -- & 8.5 & 4.5 & .4 & 53 & 960 & -- & -- & -- & -- \\
\hline 115 & $09-06-68$ & .00 & 238 & -- & 6.7 & 3.1 & 13 & 46 & 330 & .090 & -- & -- & -- \\
\hline 116 & $09-06-68$ & .00 & 230 & -- & 110 & .70 & 99 & 49 & 600 & .110 & -- & -- & -- \\
\hline 117 & $07-30-80$ & .00 & 150 & -- & 2.1 & .10 & 6.1 & 18 & 180 & .550 & -- & .550 & -- \\
\hline 118 & $08-06-68$ & .00 & 82 & -- & 1.1 & 1.1 & 27 & 31 & 160 & .020 & -- & -- & -- \\
\hline 119 & $07-31-80$ & -- & 180 & - & 10 & 1.1 & 48 & 52 & 320 & .000 & -- & .000 & -- \\
\hline 120 & $07-30-80$ & .00 & 67 & -- & .60 & .10 & 1.3 & 25 & 97 & .470 & -- & .470 & -- \\
\hline 121 & $07-29-80$ & .00 & 130 & -- & 190 & .10 & 1,300 & 5.7 & 2,200 & .510 & -- & .510 & -- \\
\hline 122 & $09-06-68$ & .00 & 148 & -- & 24 & .60 & 33 & 29 & 270 & .250 & -- & -- & -- \\
\hline 123 & $08-21-68$ & .00 & 107 & -- & 2.6 & .60 & 17 & 21 & 160 & .160 & -- & -- & -- \\
\hline 124 & $10-09-75$ & .00 & 290 & -- & 40 & 3.4 & 190 & 45 & 690 & .050 & - & .050 & -- \\
\hline 125 & $01-25-76$ & .00 & 289 & -- & 40 & 3.8 & 170 & 46 & 660 & .020 & -- & .020 & -- \\
\hline 126 & $04-20-76$ & .00 & 288 & -- & 38 & 4.6 & 160 & 47 & 650 & .010 & -- & .010 & -- \\
\hline 127 & $10-09-75$ & .00 & 275 & -- & 41 & 3.6 & 180 & 45 & 660 & .040 & -- & .040 & -- \\
\hline 128 & $01-25-76$ & .00 & 288 & -- & 39 & 3.9 & 170 & 47 & 660 & -- & -- & $<.100$ & -- \\
\hline 129 & $04-20-76$ & .00 & 289 & -- & 37 & 4.6 & 150 & 47 & 640 & -- & -- & $<.100$ & -- \\
\hline 130 & $07-29-80$ & .00 & 120 & -- & 2.5 & .50 & 17 & 22 & 160 & .250 & -- & .250 & -- \\
\hline 131 & $10-23-75$ & .00 & 95 & -- & 15 & 4.4 & 120 & 27 & 330 & .290 & -- & .290 & - \\
\hline
\end{tabular}


Table 4.--Water-quality information from selected wells and springs in the $S$ an Luis basin in Colorado and New Mexico--Continued

\begin{tabular}{|c|c|c|c|c|c|c|c|c|c|c|c|c|c|}
\hline $\begin{array}{c}\text { Site } \\
\text { obser- } \\
\text { vation } \\
\text { number }\end{array}$ & $\begin{array}{c}\text { Date } \\
\text { of } \\
\text { sample } \\
\text { (mo/d/yr) }\end{array}$ & $\begin{array}{c}\text { Nitro- } \\
\text { gen, } \\
\text { organic } \\
\text { dis- } \\
\text { solved } \\
\text { (mg/L } \\
\text { as } N \text { ) }\end{array}$ & $\begin{array}{l}\text { Nitro- } \\
\text { gen, } \\
\text { ammonia } \\
\text { plus } \\
\text { organic } \\
\text { dis- } \\
\text { solved } \\
\text { (mg/L } \\
\text { as } \mathrm{N} \text { ) }\end{array}$ & $\begin{array}{l}\text { Nitro- } \\
\text { gen, } \\
\text { dis- } \\
\text { solved } \\
\text { (mg/L } \\
\text { as N) }\end{array}$ & $\begin{array}{l}\text { Phos- } \\
\text { phorus, } \\
\text { dis- } \\
\text { solved } \\
\text { (mg/L } \\
\text { as P) }\end{array}$ & $\begin{array}{l}\text { Phos- } \\
\text { phorus, } \\
\text { ortho, } \\
\text { dis- } \\
\text { solved } \\
\text { (mg/L } \\
\text { as P) }\end{array}$ & $\begin{array}{l}\text { Phos- } \\
\text { phate, } \\
\text { ortho, } \\
\text { dis- } \\
\text { solved } \\
\text { (mg/L } \\
\text { as } \mathrm{PO}_{4} \text { ) }\end{array}$ & $\begin{array}{l}\text { Ar- } \\
\text { senic, } \\
\text { dis- } \\
\text { solved } \\
\text { ( } \mu \mathrm{g} / \mathrm{L} \\
\text { as As) }\end{array}$ & $\begin{array}{l}\text { Ar- } \\
\text { senic, } \\
\text { total } \\
(\mu g / L \\
\text { as As) }\end{array}$ & $\begin{array}{l}\text { Bar- } \\
\text { ium, } \\
\text { dis- } \\
\text { solved } \\
(\mu \mathrm{g} / \mathrm{L} \\
\text { as } \mathrm{Ba})\end{array}$ & $\begin{array}{l}\text { Boron, } \\
\text { dis- } \\
\text { solved } \\
(\mu \mathrm{g} / \mathrm{L} \\
\text { as B) }\end{array}$ & $\begin{array}{l}\text { Cad- } \\
\text { mium, } \\
\text { solved } \\
(\mu g / L \\
\text { as Cd) }\end{array}$ & $\begin{array}{l}\text { Chro- } \\
\text { mium, } \\
\text { solved } \\
\text { ( } \mu \mathrm{g} / \mathrm{L} \\
\text { as } \mathrm{Cr} \text { ) }\end{array}$ \\
\hline 1 & $03-08-83$ & -- & -- & -- & -- & -- & -- & 18 & -- & -- & 110 & $<1$ & -- \\
\hline 2 & $11-17-81$ & -- & -- & -- & -- & -- & -- & 200 & -- & -- & 60 & $<1$ & -- \\
\hline 3 & $07-23-76$ & -- & -- & -- & -- & -- & -- & -- & -- & -- & 60 & -- & -- \\
\hline 4 & $09-06-79$ & -- & -- & -- & 0.010 & -- & -- & $<1$ & -- & -- & $<20$ & -- & -- \\
\hline 5 & $07-22-76$ & -- & -- & -- & -- & -- & -- & -- & -- & -- & 250 & -- & -- \\
\hline 6 & $08-19-82$ & -- & -- & -- & -- & -- & -- & $<1$ & -- & 28 & -- & $<1$ & $<10$ \\
\hline 7 & $08-19-82$ & -- & -- & -- & -- & -- & -- & 1 & -- & 22 & -- & $<1$ & $<10$ \\
\hline 8 & $08-20-82$ & -- & -- & -- & -- & -- & -- & 1 & -- & 29 &.-- & $<1$ & $<10$ \\
\hline 9 & $09-06-79$ & -- & -- & -- & .030 & -- & -- & 1 & -- & -- & $<20$ & -- & -- \\
\hline 10 & $03-09-66$ & -- & -- & -- & -- & -- & -- & -- & -- & -- & 80 & -- & -- \\
\hline 11 & $06-01-81$ & -- & -- & -- & -- & -- & -- & -- & 4 & -- & 220 & -- & -- \\
\hline 12 & $08-13-80$ & -- & -- & -- & -- & -- & -- & -- & -- & -- & 20 & -- & -- \\
\hline 13 & $06-26-68$ & -- & -- & -- & -- & -- & -- & -- & -- & -- & 0 & -- & -- \\
\hline 14 & $06-04-82$ & -- & -- & -- & .030 & -- & -- & -- & -- & -- & -- & -- & -- \\
\hline 15 & $06-04-82$ & -- & -- & -- & .030 & -- & -- & -- & -- & -- & -- & -- & -- \\
\hline 16 & $06-04-82$ & -- & -- & -- & $<.010$ & -- & -- & -- & -- & -- & -- & -- & -- \\
\hline 17 & $06-04-82$ & -- & -- & -- & $<.010$ & -- & -- & -- & -- & -- & -- & -- & -- \\
\hline 18 & $08-29-79$ & -- & -- & -- & .020 & -- & -- & 3 & -- & -- & 30 & -- & -- \\
\hline 19 & $09-09-68$ & -- & -- & -- & -- & -- & -- & -- & -- & -- & 0 & -- & -- \\
\hline 20 & $09-10-68$ & -- & -- & -- & -- & -- & -- & -- & -- & -- & 0 & -- & -- \\
\hline 21 & $06-03-82$ & -- & -- & -- & $<.010$ & -- & -- & -- & -- & -- & -- & -- & -- \\
\hline 22 & $06-02-82$ & -- & -- & -- & $<.010$ & -- & -- & -- & -- & -- & -- & -- & -- \\
\hline 23 & $09-10-68$ & -- & -- & -- & -- & -- & -- & -- & -- & -- & 40 & -- & -- \\
\hline 24 & $08-08-68$ & -- & -- & -- & -- & -- & -- & -- & -- & -- & 20 & -- & -- \\
\hline 25 & $05-14-68$ & -- & -- & -- & -- & -- & -- & -- & -- & -- & -- & -- & -- \\
\hline 26 & $09-09-68$ & -- & -- & -- & -- & -- & -- & -- & -- & -- & 120 & -- & -- \\
\hline 27 & $04-19-76$ & -- & -- & -- & -- & 0.050 & 0.15 & -- & -- & -- & $<20$ & -- & -- \\
\hline 28 & $06-07-68$ & -- & -- & -- & -- & -- & -- & -- & -- & -- & 20 & -- & -- \\
\hline 29 & $08-20-68$ & -- & -- & -- & -- & -- & -- & -- & -- & -- & 940 & -- & -- \\
\hline 30 & $07-23-80$ & -- & -- & -- & -- & -- & -- & 8 & -- & 80 & 1,100 & 2 & 10 \\
\hline 31 & $04-19-7$ & -- & -- & -- & -- & .070 & .21 & -- & -- & -- & 60 & -- & -- \\
\hline 32 & $08-19$ & -- & -- & -- & -- & -- & -- & -- & -- & -- & 140 & -- & -- \\
\hline 33 & $06-18-68$ & -- & -- & -- & -- & -- & -- & -- & -- & -- & 0 & -- & -- \\
\hline 34 & $06-26-68$ & -- & -- & -- & -- & -- & -- & -- & -- & -- & 0 & -- & -- \\
\hline 35 & $07-22-80$ & -- & -- & -- & -- & -- & -- & -- & -- & -- & 40 & -- & -- \\
\hline 36 & $05-07-68$ & -- & -- & -- & -- & -- & -- & -- & -- & -- & 60 & -- & -- \\
\hline 37 & $09-10-$ & -- & -- & -- & -- & -- & -- & -- & -- & -- & 20 & -- & -- \\
\hline 38 & $07-22-80$ & -- & -- & -- & -- & -- & -- & 2 & -- & 60 & 30 & $<1$ & 10 \\
\hline 39 & $07-18-68$ & -- & -- & -- & -- & -- & -- & -- & -- & -- & 20 & -- & -- \\
\hline 40 & $09-10-68$ & -- & -- & -- & -- & -- & -- & -- & -- & -- & 60 & -- & -- \\
\hline 41 & $08-23-6$ & -- & -- & -- & -- & -- & -- & -- & -- & -- & 980 & -- & -- \\
\hline 42 & $06-07-68$ & -- & -- & -- & -- & -- & -- & -- & -- & -- & 0 & -- & -- \\
\hline 43 & $07-19-68$ & -- & -- & -- & -- & -- & -- & -- & -- & -- & 0 & -- & -- \\
\hline 44 & $08-05-68$ & -- & -- & -- & -- & -- & -- & -- & -- & -- & 70 & -- & -- \\
\hline 45 & $08-05-68$ & -- & -- & -- & -- & -- & -- & -- & -- & -- & 0 & -- & -- \\
\hline 46 & $05-68$ & -- & $=-$ & -- & -- & -- & -- & -- & -- & -- & 20 & -- & -- \\
\hline 47 & $08-09-68$ & -- & -- & -- & -- & - & -- & -- & -- & - & 220 & -- & - \\
\hline 48 & $08-12-75$ & -- & -- & -- & -- & .050 & .15 & 65 & -- & -- & 340 & ND & -- \\
\hline 49 & $07-31-80$ & -- & 0.78 & 0.80 & .340 & -- & -- & -- & -- & -- & -- & -- & -- \\
\hline 50 & $08-05-68$ & -- & -- & -- & -- & -- & -- & -- & -- & -- & 420 & -- & - \\
\hline
\end{tabular}


Table 4.--Water-quality information from selected wells and springs in the $S$ an Luis basin in Colorado and New Mexico--Continued

\begin{tabular}{|c|c|c|c|c|c|c|c|c|c|c|c|c|c|}
\hline $\begin{array}{l}\text { Site } \\
\text { obser- } \\
\text { vation } \\
\text { number }\end{array}$ & $\begin{array}{c}\text { Date } \\
\text { of } \\
\text { sample } \\
\text { (mo/d/yr) }\end{array}$ & $\begin{array}{c}\text { Nitro- } \\
\text { gen, } \\
\text { organic } \\
\text { dis- } \\
\text { solved } \\
\text { (mg/L } \\
\text { as } N \text { ) }\end{array}$ & $\begin{array}{l}\text { Nitro- } \\
\text { gen, } \\
\text { ammonia } \\
\text { plus } \\
\text { organic } \\
\text { dis- } \\
\text { solved } \\
\text { (mg/L } \\
\text { as } N \text { ) }\end{array}$ & $\begin{array}{l}\text { Nitro- } \\
\text { gen, } \\
\text { dis- } \\
\text { solved } \\
\text { (mg/L } \\
\text { as } N \text { ) }\end{array}$ & $\begin{array}{l}\text { Phos- } \\
\text { phorus, } \\
\text { dis- } \\
\text { solved } \\
\text { (mg/L } \\
\text { as P) }\end{array}$ & $\begin{array}{l}\text { Phos- } \\
\text { phorus, } \\
\text { ortho, } \\
\text { dis- } \\
\text { solved } \\
\text { (mg/L } \\
\text { as P) }\end{array}$ & $\begin{array}{l}\text { Phos- } \\
\text { phate, } \\
\text { ortho, } \\
\text { dis- } \\
\text { solved } \\
\left(\mathrm{mg}_{\mathrm{I}} \mathrm{L}\right. \\
\left.\text { as } \mathrm{PO}_{4}\right)\end{array}$ & $\begin{array}{l}\text { Ar- } \\
\text { senic, } \\
\text { dis- } \\
\text { solved } \\
(\mu g / L \\
\text { as As) }\end{array}$ & $\begin{array}{l}\text { Ar- } \\
\text { senic, } \\
\text { total } \\
(\mu g / L \\
\text { as As) }\end{array}$ & $\begin{array}{l}\text { Bar- } \\
\text { ium, } \\
\text { dis- } \\
\text { solved } \\
(\mu g / L \\
\text { as } B a)\end{array}$ & $\begin{array}{l}\text { Boron, } \\
\text { dis- } \\
\text { solved } \\
(\mu g / L \\
\text { as B) }\end{array}$ & $\begin{array}{l}\text { Cad- } \\
\text { mium, } \\
\text { solved } \\
(\mu \mathrm{g} / \mathrm{L} \\
\text { as Cd) }\end{array}$ & $\begin{array}{l}\text { Chro- } \\
\text { mium, } \\
\text { solved } \\
(\mu g / L \\
\text { as Cr) }\end{array}$ \\
\hline 51 & $08-05-68$ & -- & - & -- & -- & -- & - & -- & -- & -- & 20 & -- & $\ldots$ \\
\hline 52 & $08-05-68$ & $\ldots$ & $\ldots$ & - & $\ldots$ & -- & -- & -- & - & - & 0 & - & -- \\
\hline 53 & $08-09-68$ & - & -- & -- & - & -- & -- & -- & -- & -- & 120 & -- & -- \\
\hline 54 & $08-05-68$ & $\ldots$ & $\ldots$ & $\ldots$ & $\ldots$ & - & - & - & $\ldots$ & - & 70 & - & - \\
\hline 55 & $08-22-78$ & 1.1 & 1.1 & 1.1 & $<0.010$ & 0.010 & 0.03 & 2 & -- & -- & 70 & 2 & ND \\
\hline 56 & $07-18-68$ & $\ldots$ & $\ldots$ & - & -- & -- & - & -- & - & -- & 100 & $\ldots$ & -- \\
\hline 57 & $08-07-68$ & -- & - & - & -- & -- & -- & - & - & - & 60 & - & - \\
\hline 58 & $08-07-68$ & -- & -- & -- & -- & -- & -- & - & -- & -- & 0 & -- & -- \\
\hline 59 & $08-07-68$ & $\ldots$ & $\ldots$ & - & - & - & - & - & -- & -- & 240 & - & - \\
\hline 60 & $08-07-68$ & -- & -- & -- & -- & -- & -- & - & -- & -- & 200 & $\cdots$ & -- \\
\hline 61 & $09-09-68$ & - & -- & -- & - & -- & -- & -- & -- & -- & 340 & -- & -- \\
\hline 62 & $08-05-68$ & -- & -- & -- & -- & -- & -- & -- & -- & - & 0 & -- & -- \\
\hline 63 & $07-03-68$ & -- & - & -- & -- & -- & -- & -- & -- & -- & 180 & -- & - \\
\hline 64 & $08-08-68$ & -- & -- & -- & -- & -- & -- & -- & -- & -- & 270 & -- & -- \\
\hline 65 & $08-07-68$ & -- & -- & - & -- & $\cdots$ & -- & - & -- & $\cdots$ & 0 & - & -- \\
\hline 66 & $11-01-68$ & -- & -- & -- & -- & -- & -- & -- & -- & -- & - & - & -- \\
\hline 67 & $11-01-68$ & $\ldots$ & $\cdots$ & -- & -- & $\ldots$ & -- & -- & -- & -- & -- & -- & - \\
\hline 68 & $11-01-68$ & -- & $\cdots$ & $\cdots$ & -- & -- & -- & -- & -- & -- & -- & -- & -- \\
\hline 69 & $08-08-68$ & - & -- & -- & -- & -- & $\ldots$ & - & $\ldots$ & - & 310 & -- & -- \\
\hline 70 & $08-07-68$ & -- & -- & -- & -- & -- & -- & -- & -- & -- & 610 & -- & -- \\
\hline 71 & $07-26-68$ & - & - & - & - & -- & - & - & -- & - & 0 & - & - \\
\hline 72 & $08-07-68$ & -- & -- & -- & -- & -- & -- & - & -- & - & 640 & -- & -- \\
\hline 73 & $08-06-68$ & -- & -- & -- & -- & -- & -- & -- & -- & -- & 680 & -- & -- \\
\hline 74 & $08-06-68$ & -- & -- & -- & -- & -- & -- & - & -- & -- & 350 & -- & -- \\
\hline 75 & $08-08-68$ & $\cdots$ & - & -- & -- & - & -- & -- & -- & -- & 310 & $\cdots$ & -- \\
\hline 76 & $08-28-79$ & -- & - & -- & .030 & -- & -- & 60 & -- & -- & 2,000 & -- & -- \\
\hline 77 & $08-06-68$ & -- & - & -- & -- & -- & - & - & -- & -- & 0 & - & -- \\
\hline 78 & $08-06-68$ & - & -- & -- & -- & -- & - & -- & -- & -- & 0 & -- & -- \\
\hline 79 & $08-06-68$ & -- & - & - & -- & - & - & - & -- & -- & 40 & -- & -- \\
\hline 80 & $08-06-68$ & -- & -- & -- & -- & -- & - & - & - & - & 70 & -- & -- \\
\hline 81 & $09-06-68$ & $\ldots$ & - & $\ldots$ & $\ldots$ & - & - & -- & -- & - & 200 & -- & -- \\
\hline 82 & $09-06-68$ & -- & -- & -- & -- & -- & -- & $\ldots$ & -- & -- & 30 & -- & -- \\
\hline 83 & $08-06-68$ & -- & -- & -- & -- & - & -- & $\ldots$ & -- & -- & 290 & - & -- \\
\hline 84 & $07-31-80$ & -- & -- & -- & -- & -- & -- & 33 & -- & 20 & 380 & 2 & 10 \\
\hline 85 & $08-09-68$ & $\cdots$ & $\cdots$ & $\cdots$ & -- & $\cdots$ & -- & $\ldots$ & - & -- & 490 & -- & -- \\
\hline 86 & $03-25-81$ & .91 & .91 & 3.8 & - & - & -- & -- & -- & -- & -- & -- & -- \\
\hline 87 & $08-23-78$ & .19 & .35 & .41 & $<.010$ & $<.010$ & .00 & 1 & -- & - & 40 & 12 & ND \\
\hline 88 & $05-08-80$ & -- & .54 & 1.1 & .100 & -- & -- & -- & -- & -- & -- & -- & -- \\
\hline 89 & $07-31-80$ & -- & -- & $=-$ & -- & -- & -- & 3 & -- & 200 & 90 & $<1$ & 0 \\
\hline 90 & $05-08-80$ & -- & .37 & .46 & .050 & -- & -- & -- & - & -- & - & - & -- \\
\hline 91 & $08-29-79$ & -- & -- & -- & $<.010$ & - & - & 1 & -- & - & 60 & -- & -- \\
\hline 92 & $10-21-75$ & -- & -- & -- & -- & .020 & .06 & 2 & -- & - & 2,500 & ND & - \\
\hline 93 & $01-27-76$ & -- & -- & -- & -- & .060 & .18 & -- & -- & -- & 1,300 & $\cdots$ & -- \\
\hline 94 & $04-21-76$ & -- & - & - & -- & .080 & .25 & - & -- & -- & 2,600 & -- & -- \\
\hline 95 & $08-13-75$ & -- & -- & -- & -- & .010 & .03 & 22 & -- & 160 & 2,600 & ND & $<10$ \\
\hline 96 & $10-21-75$ & - & - & -- & -- & .020 & .06 & 21 & -- & -- & 2,500 & ND & $\cdots$ \\
\hline 97 & $01-27-76$ & - & -- & -- & - & .070 & .21 & -- & - & - & 1,300 & -- & -- \\
\hline 98 & $04-18-76$ & -- & - & - & - & .100 & .31 & - & $\cdots$ & - & 2,600 & -- & -- \\
\hline 99 & $07-18-68$ & -- & -- & -- & -- & -- & -- & -- & -- & -- & 800 & -- & -- \\
\hline 100 & $08-20-76$ & -- & $-\infty$ & -- & -- & - & -- & 0 & - & -- & 140 & ND & -- \\
\hline
\end{tabular}


Table 4.--Water-quality information from selected wells and springs in the $S$ an Luis bas in in Colorado and New Mexico--Continued

\begin{tabular}{|c|c|c|c|c|c|c|c|c|c|c|c|c|c|}
\hline $\begin{array}{l}\text { Site } \\
\text { obser- } \\
\text { vation } \\
\text { number }\end{array}$ & $\begin{array}{c}\text { Date } \\
\text { of } \\
\text { sample } \\
\text { (mo/d/yr) }\end{array}$ & $\begin{array}{c}\text { Nitro- } \\
\text { gen, } \\
\text { organic } \\
\text { dis- } \\
\text { solved } \\
(\mathrm{mg} / \mathrm{L} \\
\text { as } \mathrm{N})\end{array}$ & $\begin{array}{l}\text { Nitro- } \\
\text { gen, } \\
\text { ammonia } \\
\text { plus } \\
\text { organic } \\
\text { dis- } \\
\text { solved } \\
\text { (mg/L } \\
\text { as } N \text { ) }\end{array}$ & $\begin{array}{l}\text { Nitro- } \\
\text { gen, } \\
\text { dis- } \\
\text { solved } \\
\text { (mg/L } \\
\text { as N) }\end{array}$ & $\begin{array}{l}\text { Phos- } \\
\text { phorus, } \\
\text { dis- } \\
\text { solved } \\
\text { (mg/L } \\
\text { as P) }\end{array}$ & $\begin{array}{l}\text { Phos- } \\
\text { phorus, } \\
\text { ortho, } \\
\text { dis- } \\
\text { solved } \\
\text { (mg/L } \\
\text { as P) }\end{array}$ & $\begin{array}{l}\text { Phos- } \\
\text { phate, } \\
\text { ortho, } \\
\text { dis- } \\
\text { solved } \\
\left(\mathrm{mg}^{2} \mathrm{~L}\right. \\
\left.\text { as } \mathrm{PO}_{4}\right)\end{array}$ & $\begin{array}{l}\text { Ar- } \\
\text { senic, } \\
\text { dis- } \\
\text { solved } \\
(\mu g / L \\
\text { as As) }\end{array}$ & $\begin{array}{l}\text { Ar- } \\
\text { senic, } \\
\text { total } \\
\text { ( } \mu \mathrm{g} / \mathrm{L} \\
\text { as As) }\end{array}$ & $\begin{array}{l}\text { Bar- } \\
\text { ium, } \\
\text { dis- } \\
\text { solved } \\
(\mu g / L \\
\text { as } \mathrm{Ba})\end{array}$ & $\begin{array}{l}\text { Boron, } \\
\text { dis- } \\
\text { solved } \\
(\mu g / L \\
\text { as B) }\end{array}$ & $\begin{array}{l}\text { Cad- } \\
\text { mium, } \\
\text { solved } \\
\text { ( } \mu g / L \\
\text { as Cd) }\end{array}$ & $\begin{array}{l}\text { Chro- } \\
\text { mium, } \\
\text { solved } \\
(\mu g / L \\
\text { as } C r)\end{array}$ \\
\hline 101 & $08-23-78$ & 0.00 & 2.1 & 2.1 & 0.080 & 0.090 & 0.28 & 2 & -- & -- & 50 & 4 & ND \\
\hline 102 & $09-06-68$ & -- & -- & -- & -- & -- & -- & - & -- & -- & 100 & - & -- \\
\hline 103 & $07-11-68$ & -- & -- & - & -- & -- & -- & -- & -- & -- & 70 & -- & -- \\
\hline 104 & $08-23-78$ & .37 & .88 & 1.0 & .230 & .250 & .77 & 9 & -- & $\cdots$ & 370 & 4 & $<20$ \\
\hline 105 & $09-06-68$ & -- & - & $\cdots$ & -- & -- & - & -- & -- & -- & 50 & - & $=-$ \\
\hline 106 & $08-23-78$ & .10 & 2.8 & 2.8 & .090 & .120 & .37 & 1 & -- & -- & 70 & $<20$ & ND \\
\hline 107 & $05-08-80$ & -- & 1.3 & 2.9 & .200 & -- & -- & - & -- & -- & -- & $\cdots$ & -- \\
\hline 108 & $03-25-81$ & 1.0 & 1.0 & 2.1 & -- & -- & -- & -- & -- & -- & -- & -- & -- \\
\hline 109 & $08-01-80$ & -- & -- & -- & -- & -- & -- & -- & -- & -- & 480 & -- & -- \\
\hline 110 & $08-23-78$ & .48 & 1.4 & 1.4 & .110 & .120 & .37 & 1 & -- & -- & 160 & 3 & $<20$ \\
\hline 111 & $08-23-78$ & 1.5 & 2.3 & 2.3 & .020 & $<.010$ & .00 & 1 & -- & -- & 40 & 18 & ND \\
\hline 112 & $09-12-68$ & -- & -- & - & -- & -- & -- & $\cdots$ & -- & -- & 20 & -- & -- \\
\hline 113 & $05-08-80$ & -- & 1.1 & 1.1 & .020 & -- & -- & -- & -- & -- & -- & -- & -- \\
\hline 114 & $12-17-68$ & -- & -- & -- & -- & -- & -- & -- & -- & -- & -- & -- & -- \\
\hline 115 & $09 / 06 / 68$ & -- & -- & -- & -- & -- & -- & -- & -- & -- & 50 & -- & -- \\
\hline 116 & $09-06-68$ & -- & -- & -- & -- & -- & -- & -- & - & -- & 80 & -- & -- \\
\hline 117 & $07-30-80$ & -- & -- & $\cdots$ & -- & -- & -- & 2 & -- & 100 & 30 & $<1$ & .00 \\
\hline 118 & $08-06-68$ & -- & -- & $\cdots$ & -- & -- & -- & -- & -- & -- & 20 & -- & -- \\
\hline 119 & $07-31-80$ & -- & .48 & .48 & .130 & -- & -- & -- & -- & -- & -- & -- & -- \\
\hline 120 & $07-30-80$ & -- & -- & -- & -- & -- & $\cdots$ & -- & -- & -- & 10 & -- & -- \\
\hline 121 & $07-29-80$ & -- & -- & - & -- & -- & -- & -- & -- & -- & 30 & -- & -- \\
\hline 122 & $09-06-68$ & -- & -- & $\cdots$ & -- & -- & -- & -- & -- & -- & 30 & -- & -- \\
\hline 123 & $08-21-68$ & -- & -- & - & -- & -- & -- & -- & -- & -- & 30 & -- & -- \\
\hline 124 & $10-09-75$ & -- & -- & $\cdots$ & -- & .010 & .03 & 36 & $\cdots$ & -- & 350 & $<2$ & -- \\
\hline 125 & $01-25-76$ & - & - & $\cdots$ & -- & $<.010$ & .00 & -- & - & -- & 340 & -- & -- \\
\hline 126 & $04-20-76$ & -- & -- & -- & -- & .040 & .12 & -- & -- & -- & 400 & -- & -- \\
\hline 127 & $10-09-75$ & -- & -- & -- & -- & .010 & .03 & 32 & -- & -- & 350 & $<2$ & -- \\
\hline 128 & $01-25-76$ & -- & -- & $\cdots$ & $\cdots$ & $<.010$ & .00 & - & $\cdots$ & -- & 370 & -- & -- \\
\hline 129 & $04-20-76$ & -- & -- & $\cdots$ & $\cdots$ & .040 & .12 & -- & - & -- & 450 & -- & -- \\
\hline 130 & $07-29-80$ & -- & -- & -- & -- & -- & -- & 2 & -- & 60 & 40 & 2 & .00 \\
\hline 131 & $10-23-75$ & - & - & - & -- & .020 & .06 & 1 & -- & -- & 50 & ND & - \\
\hline
\end{tabular}


Table 4.--Water-quality information from selected wells and springs in the San Luis basin in Colorado and New Mexico--Continued

\begin{tabular}{|c|c|c|c|c|c|c|c|c|c|c|c|c|}
\hline $\begin{array}{l}\text { Site } \\
\text { obser- } \\
\text { vation } \\
\text { number }\end{array}$ & $\begin{array}{l}\text { Date of } \\
\text { sample } \\
\text { (mo/d/yr) }\end{array}$ & $\begin{array}{l}\text { Copper, } \\
\text { dis- } \\
\text { solved } \\
(\mu g / L \\
\text { as } \mathrm{Cu})\end{array}$ & $\begin{array}{l}\text { Iron, } \\
\text { dis- } \\
\text { solved } \\
(\mu g / L \\
\text { as } \mathrm{Fe})\end{array}$ & $\begin{array}{l}\text { Lead, } \\
\text { dis- } \\
\text { solved } \\
(\mu \mathrm{g} / \mathrm{L} \\
\text { as } \mathrm{Pb})\end{array}$ & $\begin{array}{c}\text { Lithium, } \\
\text { dis- } \\
\text { solved } \\
(\mu g / L) \\
\text { as } L i)\end{array}$ & $\begin{array}{l}\text { Manga- } \\
\text { nese, } \\
\text { dis- } \\
\text { solved } \\
(\mu g / L \\
\text { as } M n)\end{array}$ & $\begin{array}{c}\text { Mercury, } \\
\text { dis- } \\
\text { solved } \\
(\mu g / L \\
\text { as } \mathrm{Hg})\end{array}$ & $\begin{array}{l}\text { Nickel, } \\
\text { dis- } \\
\text { solved } \\
\left(\mu_{g} / \mathrm{L}\right. \\
\text { as } \mathrm{Ni})\end{array}$ & $\begin{array}{l}\text { Sele- } \\
\text { nium, } \\
\text { dis- } \\
\text { solved } \\
\left(\mu_{g} / \mathrm{L}\right. \\
\text { as } \mathrm{Se})\end{array}$ & $\begin{array}{l}\text { Silver, } \\
\text { dis- } \\
\text { solved } \\
(\mu g / L \\
\text { as } A g)\end{array}$ & $\begin{array}{l}\text { Zinc, } \\
\text { dis- } \\
\text { solved } \\
(\mu g / L \\
\text { as } Z n)\end{array}$ & $\begin{array}{c}\text { Carbon } \\
\text { organic, } \\
\text { dis- } \\
\text { solved } \\
\text { (mg/L } \\
\text { as C) }\end{array}$ \\
\hline 1 & $03-08-83$ & -- & 40 & 5 & -- & 13 & $<0.1$ & -- & 1 & -- & -- & -- \\
\hline 2 & $11-17-81$ & -- & $<10$ & $<1$ & -- & - & $<.1$ & - & $<1$ & -- & -- & -- \\
\hline 3 & $07-23-76$ & -- & -- & -- & 90 & -- & $\cdots$ & -- & -- & -- & $-\infty$ & -- \\
\hline 4 & $09-06-79$ & -- & $<10$ & -- & 5 & $<1$ & - & -- & -- & - & -- & -- \\
\hline 5 & $07-22-76$ & -- & -- & -- & 270 & -- & -- & -- & -- & -- & -- & -- \\
\hline 6 & $08-19-82$ & 1 & 6 & $<1$ & -- & 3 & $<.1$ & -- & $<1$ & $<1$ & 40 & -- \\
\hline 7 & $08-19-82$ & $<1$ & 8 & 1 & -- & 5 & $<.1$ & -- & $<1$ & $<1$ & 3 & -- \\
\hline 8 & $08-20-82$ & $<1$ & 4 & $<1$ & -- & 3 & $<.1$ & $-n$ & $<1$ & $<1$ & 13 & -- \\
\hline 9 & $09-06-79$ & -- & $<10$ & -- & 20 & $<1$ & -- & -- & -- & $-m$ & -- & -- \\
\hline 10 & $03-09-66$ & 10 & 10 & 0 & -- & -- & - & - & -- & -- & 60 & - \\
\hline 11 & $06-01-81$ & -- & 80 & -- & -- & 6 & -- & -- & -- & -- & -- & -- \\
\hline 12 & $08-13-80$ & -- & 20 & -- & - & 2 & -- & -- & -- & -- & -- & -- \\
\hline 13 & $06-26-68$ & -- & -- & $=-$ & -- & -- & $-\infty$ & $\cdots$ & -- & -- & -- & -- \\
\hline 14 & $06-04-82$ & -- & 3 & -- & -- & $<1$ & -- & -- & - & -- & - & - \\
\hline 15 & $06-04-82$ & -- & 8 & -- & -- & 3 & -- & - & - & -- & -- & -- \\
\hline 16 & $06-04-82$ & -- & 14 & $-\infty$ & -- & 3 & - & - & - & -- & - & - \\
\hline 17 & $06-04-82$ & -- & 9 & -- & -- & $<1$ & -- & -- & -- & -- & -- & -- \\
\hline 18 & $08-29-79$ & -- & 30 & -- & 9 & $<1$ & - & -- & -- & - & -- & -- \\
\hline 19 & $09-09-68$ & -- & -- & -- & -- & -- & -- & -- & -- & -- & -- & -- \\
\hline 20 & $09-10-68$ & -- & -- & -- & -- & -- & -- & -- & -- & $\cdots$ & -- & $\cdots$ \\
\hline 21 & $06-03-82$ & - & 8 & -- & -- & 1 & -- & -- & -- & -- & -- & -- \\
\hline 22 & $06-02-82$ & -- & 22 & -- & -- & 7 & -- & - & - & -- & -- & -- \\
\hline 23 & $09-10-68$ & -- & -- & -- & -- & -- & -- & -- & -- & -- & -- & $m$ \\
\hline 24 & $08-08-68$ & -- & -- & -- & -- & -- & -- & -- & -- & -- & -- & -- \\
\hline 25 & $05-14-68$ & -- & -- & -- & -- & -- & -- & -- & -- & -- & -- & + \\
\hline 26 & $09-09-68$ & -- & - & -- & -- & - & - & -- & -- & -- & -- & -- \\
\hline 27 & $04-19-76$ & -- & $<10$ & -- & -- & $<10$ & $-\infty$ & -- & -- & -- & -- & $\cdots$ \\
\hline 28 & $06-07-68$ & -- & -- & -- & -- & - & -- & -- & -- & -- & -- & - \\
\hline 29 & $08-20-68$ & -- & -- & -- & -- & -- & -- & -- & -- & -- & -- & -- \\
\hline 30 & $07-23-80$ & 3 & 40 & 0 & -- & 1 & .7 & -- & 0 & 0 & 7 & -- \\
\hline 31 & $04-19-76$ & - & $<10$ & -- & - & $<10$ & -- & - & - & -- & -- & -- \\
\hline 32 & $08-19-68$ & -- & -- & - & -- & -- & $-\infty$ & -- & -- & -- & -- & -- \\
\hline 33 & $06-18-68$ & -- & -- & -- & - & - & - & -- & -- & -- & -- & -- \\
\hline 34 & $06-26-68$ & -- & -- & $\cdots$ & -- & -- & $-\cdots$ & -- & -- & $-\cdots$ & -- & -- \\
\hline 35 & $07-22-80$ & -- & 20 & -- & -- & 1 & - & -- & - & -- & - & -- \\
\hline 36 & $05-07-68$ & -- & -- & -- & -- & -- & - & -- & -- & -- & -- & -- \\
\hline 37 & $09-10-68$ & -- & -- & -- & -- & -- & - & -- & $m$ & - & -- & -- \\
\hline 38 & $07-22-80$ & 0 & $<10$ & 0 & - & $<1$ & .6 & -- & 0 & 0 & 3 & $m$ \\
\hline 39 & $07-18-68$ & -- & $\cdots$ & -- & -- & - & -- & $\cdots$ & -- & -- & -- & -- \\
\hline 40 & $09-10-68$ & -- & $\cdots$ & - & $\cdots$ & $\cdots$ & $\cdots$ & $m$ & -- & -- & -- & - \\
\hline 41 & $08-23-68$ & -- & -- & $-\infty$ & -- & -- & -- & $\cdots$ & -- & $\cdots$ & -- & -- \\
\hline 42 & $06-07-68$ & -- & -- & -- & -- & -- & - & - & - & - & - & - \\
\hline 43 & $07-19-68$ & -- & -- & $-\infty$ & -- & - & -- & -- & -- & -- & -- & -- \\
\hline 44 & $08-05-68$ & -- & -- & $-\infty$ & -- & - & -- & -- & -- & -- & -- & -- \\
\hline 45 & $08-05-68$ & -- & -- & $-\infty$ & -- & - & -- & -- & - & - & - & $m$ \\
\hline 46 & $08-05-68$ & -- & -- & $-\infty$ & -- & - & -- & -- & - & -- & - & -- \\
\hline 47 & $08-09-68$ & -- & -- & -- & -- & -- & $-\infty$ & -- & - & -- & -- & -- \\
\hline 48 & $08-12-75$ & -- & 20 & -- & $<10$ & $<10$ & $<.5$ & -- & $<1$ & -- & ND & -- \\
\hline 49 & $07-31-80$ & -- & 2,300 & $-\cdots$ & -- & 1,700 & $\cdots$ & -- & -- & -- & -- & -- \\
\hline 50 & $08-05-68$ & -- & -- & -- & -- & -- & -- & $m$ & -- & -- & -- & - \\
\hline
\end{tabular}


Table 4.--Water-quality information from selected wells and springs in the San Luis basin in Colorado and New Mexico--Continued

\begin{tabular}{|c|c|c|c|c|c|c|c|c|c|c|c|c|}
\hline $\begin{array}{l}\text { Site } \\
\text { obser- } \\
\text { vation } \\
\text { number }\end{array}$ & $\begin{array}{l}\text { Date of } \\
\text { sample } \\
\text { (mo/d/yr) }\end{array}$ & $\begin{array}{c}\text { Copper, } \\
\text { dis- } \\
\text { solved } \\
(\mu \mathrm{g} / \mathrm{L} \\
\text { as } \mathrm{Cu})\end{array}$ & $\begin{array}{l}\text { Iron, } \\
\text { dis- } \\
\text { solved } \\
(\mu \mathrm{g} / \mathrm{L} \\
\text { as } \mathrm{Fe})\end{array}$ & $\begin{array}{l}\text { Lead, } \\
\text { dis- } \\
\text { solved } \\
\text { ( } \mu \mathrm{g} / \mathrm{L} \\
\text { as } \mathrm{Pb})\end{array}$ & $\begin{array}{c}\text { Lithium, } \\
\text { dis- } \\
\text { solved } \\
\text { ( } \mu \mathrm{g} / \mathrm{L}) \\
\text { as } \mathrm{Li})\end{array}$ & $\begin{array}{l}\text { Manga- } \\
\text { nese, } \\
\text { dis- } \\
\text { solved } \\
(\mu \mathrm{L} / \mathrm{L} \\
\text { as } \mathrm{Mn})\end{array}$ & $\begin{array}{c}\text { Mercury, } \\
\text { dis- } \\
\text { solved } \\
\text { ( } \mu \mathrm{g} / \mathrm{L} \\
\text { as } \mathrm{Hg})\end{array}$ & $\begin{array}{l}\text { Nickel, } \\
\text { dis- } \\
\text { solved } \\
(\mu \mathrm{g} / \mathrm{L} \\
\text { as } \mathrm{Ni})\end{array}$ & $\begin{array}{l}\text { Sele- } \\
\text { nium, } \\
\text { dis- } \\
\text { solved } \\
\text { ( } \mu \mathrm{g} / \mathrm{L} \\
\text { as } \mathrm{Se} \text { ) }\end{array}$ & $\begin{array}{l}\text { Silver, } \\
\text { dis- } \\
\text { solved } \\
(\mu g / L \\
\text { as Ag) }\end{array}$ & $\begin{array}{l}\text { Zinc, } \\
\text { dis- } \\
\text { solved } \\
(\mu \mathrm{g} / \mathrm{L} \\
\text { as } \mathrm{Zn})\end{array}$ & $\begin{array}{c}\text { Carbon } \\
\text { organic, } \\
\text { dis- } \\
\text { solved } \\
\text { (mg/L } \\
\text { as C) }\end{array}$ \\
\hline 51 & $08-05-68$ & -- & -- & -- & -- & -- & -- & -- & -- & -- & -- & -- \\
\hline 52 & $08-05-68$ & -- & -- & $\cdots$ & -- & -- & -- & -- & -- & -- & -- & -- \\
\hline 53 & $08-09-68$ & -- & -- & -- & -- & -- & -- & -- & -- & -- & -- & -- \\
\hline 54 & $08-05-68$ & -- & -- & -- & -- & -- & -- & -- & -- & -- & -- & -- \\
\hline 55 & $08-22-78$ & ND & 260 & 23 & -- & 40 & $<0.1$ & ND & $<1$ & $\therefore$ & 100 & 2.8 \\
\hline 56 & $07-18-68$ & - & -- & -- & -- & -- & -- & -- & -- & -- & -- & -. \\
\hline 57 & $08-07-68$ & -- & -- & -- & -- & -- & -- & -- & -- & -- & -- & -- \\
\hline 58 & $08-07-68$ & -- & -- & -- & -- & -- & -- & -- & -- & -- & -- & -- \\
\hline 59 & $08-09-68$ & -- & -- & -- & -- & -- & -- & -- & -- & -- & -- & -- \\
\hline 60 & $08-07-68$ & -- & -- & -- & -- & -- & -- & -- & -- & -- & -- & -- \\
\hline 61 & $09-09-68$ & -- & -- & -- & -- & -- & -- & -. & -- & -- & -- & -- \\
\hline 62 & $08-05-68$ & -- & -- & -- & -- & -- & -- & -- & -- & -- & -- & -- \\
\hline 63 & $07-03-68$ & -- & -- & -- & -- & -- & -- & -- & -- & -- & -- & -- \\
\hline 64 & $08-08-68$ & -- & -- & -- & -- & -- & -- & -- & -- & -- & -- & -- \\
\hline 65 & $08-07-68$ & -- & -- & -- & -- & -- & -- & -- & -- & -- & -- & -- \\
\hline 66 & $11-01-68$ & -- & -. & - & -. & -- & -- & -- & -- & -- & -. & $\ldots$ \\
\hline 67 & $11-01-68$ & -- & -- & - & -- & -- & -- & -- & -. & -- & -- & -- \\
\hline 68 & $11-01-68$ & -- & -- & -- & -- & -- & -- & -- & -- & -- & -- & -- \\
\hline 69 & $08-08-68$ & -- & $\cdots$ & -- & $\cdots$ & -- & -- & -- & $\cdots$ & -- & -- & -- \\
\hline 70 & $08-07-68$ & -. & -- & -- & - & -- & -- & -- & -- & -- & -- & -- \\
\hline 71 & $08-07-68$ & -- & -. & -. & -- & -. & -. & -. & -. & -- & -. & -- \\
\hline 72 & $07-26-68$ & -- & -- & -- & -- & -- & -- & -- & -- & -- & -- & -- \\
\hline 73 & $08-06-68$ & -- & $\cdots$ &.- & -- & -- & -- & -- & -. & -- & - & -- \\
\hline 74 & $08-06-68$ & -- & - & - & -- & -- & -- & -- & -- & -- & -- & -- \\
\hline 75 & $08-06-68$ & -. & $\cdots$ & -- & -- & $\cdots$ & -- & -- & -- & $\cdots$ & -- & -- \\
\hline 76 & $08-28-79$ & -- & $<10$ & -- & - & 2 & -- & -- & -- & -- & -- & -- \\
\hline 77 & $08-06-68$ & $\cdots$ & -- & -- & -- & -- & -- & -- & -- & -- & -- & -- \\
\hline 78 & $08-06-68$ & -- & -- & -- & -- & -- & -- & -- & -- & -- & -- & -- \\
\hline 79 & $08-06-68$ & -- & -- & -- & -- & -- & -- & -- & -- & -- & -- & -- \\
\hline 80 & $08-06-68$ & -- & -- & -- & -- & -- & -- & -- & -- & -- & -- & -- \\
\hline 81 & $09-06-68$ & - & -. & -- & -. & -- & -- & -- & -- & -- & -- & -- \\
\hline 82 & $09-06-68$ & -- & -- & -- & -- & -- & -- & -- & -- & -- & -- & -- \\
\hline 83 & $08-06-68$ & -- & -- & -- & -- & -- & -- & -- & -- & -- & -- & -- \\
\hline 84 & $07-31-80$ & -- & 120 & 0 & -- & 6 & .5 & -- & 0 & 0 & 3 & -- \\
\hline 85 & $08-09-68$ & -- & -- & -- & -- & -- & -- & -- & -- & -- & -- & -- \\
\hline 86 & $03-25-81$ & -- & -- & -- & -- & -- & -- & -. & -- & -- & -- & -- \\
\hline 87 & $08-23-78$ & ND & 20 & 88 & -- & 40 & $<.1$ & ND & $<1$ & -- & ND & 1.9 \\
\hline 88 & $05-08-80$ & -- & $<10$ & -- & -- & 110 & -- & - & -- & -- & -- & -- \\
\hline 89 & $07-31-80$ & 2 & 20 & 0 & -- & $<1$ & .8 & -. & 0 & 0 & 6 & -- \\
\hline 90 & $05-08-80$ & -- & 50 & -- & -- & 10 & -- & -- & -- & -- & -- & -- \\
\hline 91 & $08-29-79$ & -- & 30 & -- & 40 & $<10$ & -- & -- & - & - & -. & -- \\
\hline 92 & $10-21-75$ & -- & 250 & -- & 2,000 & 530 & $<.5$ & -- & $<1$ & -- & 2 & -- \\
\hline 93 & $01-27-76$ & - & 120 & -- & -- & 560 & -- & -- & -- & -- & -- & -- \\
\hline 94 & $04-21-76$ & -- & 170 & -- & $\cdots$ & 540 & -- & -- & -- & -- & $\cdots$ & $\cdots$ \\
\hline 95 & $08-13-75$ & $<3$ & 30 & 30 & 2,000 & 280 & $<.5$ & $<11$ & $<1$ & ND & $<20$ & -- \\
\hline 96 & $10-21-75$ & -- & 30 & -- & 2,200 & 310 & $<.5$ & -- & $<1$ & -- & 20 & -- \\
\hline 97 & $01-27-76$ & - & $<10$ & - & -- & 320 & -- & -. & -- & -- & -- & -- \\
\hline 98 & $04-18-76$ & -- & $<10$ & -- & -- & 300 & -- & -- & -- & -- & $-\cdot$ & -- \\
\hline 99 & $07-18-68$ & -- & -- & -- & -- & -- & -- & -- & -- & -- & -- & -- \\
\hline 100 & $08-20-76$ & -- & 40 & - & 30 & $<10$ & $<.5$ & -. & $<1$ & -- & 5 & -- \\
\hline
\end{tabular}


Table 4,--Water-quality information from selected wells and springs in the $S$ an Luis basin in Colorado and New Mexico--Continued

\begin{tabular}{|c|c|c|c|c|c|c|c|c|c|c|c|c|}
\hline $\begin{array}{l}\text { Site } \\
\text { obser- } \\
\text { vation } \\
\text { number }\end{array}$ & $\begin{array}{l}\text { Date of } \\
\text { sample } \\
\text { (mo/d/yr) }\end{array}$ & $\begin{array}{l}\text { Copper, } \\
\text { dis- } \\
\text { solved } \\
(\mu \mathrm{g} / \mathrm{L} \\
\text { as } \mathrm{Cu})\end{array}$ & $\begin{array}{l}\text { Iron, } \\
\text { dis- } \\
\text { solved } \\
(\mu \mathrm{g} / \mathrm{L} \\
\text { as } \mathrm{Fe})\end{array}$ & $\begin{array}{l}\text { Lead, } \\
\text { dis- } \\
\text { solved } \\
(\mu g / L \\
\text { as } \mathrm{Pb})\end{array}$ & $\begin{array}{c}\text { Lithium, } \\
\text { dis- } \\
\text { solved } \\
(\mu \mathrm{g} / \mathrm{L}) \\
\text { as } \mathrm{Li})\end{array}$ & $\begin{array}{l}\text { Manga- } \\
\text { nese, } \\
\text { dis- } \\
\text { solved } \\
(\mu g / L \\
\text { as } \mathrm{Mn})\end{array}$ & $\begin{array}{c}\text { Mercury, } \\
\text { dis- } \\
\text { solved } \\
\text { ( } \mu \mathrm{g} / \mathrm{L} \\
\text { as } \mathrm{Hg} \text { ) }\end{array}$ & $\begin{array}{l}\text { Nickel, } \\
\text { dis- } \\
\text { solved } \\
(\mu \mathrm{g} / \mathrm{L} \\
\text { as } \mathrm{Ni})\end{array}$ & $\begin{array}{l}\text { Sele- } \\
\text { nium, } \\
\text { dis- } \\
\text { solved } \\
(\mu \mathrm{g} / \mathrm{L} \\
\text { as } \mathrm{Se})\end{array}$ & $\begin{array}{l}\text { Silver, } \\
\text { dis- } \\
\text { solved } \\
\text { ( } \mu \mathrm{g} / \mathrm{L} \\
\text { as } \mathrm{Ag})\end{array}$ & $\begin{array}{l}\text { Zinc, } \\
\text { dis- } \\
\text { solved } \\
(\mu g / L \\
\text { as } Z n)\end{array}$ & $\begin{array}{c}\text { Carbon } \\
\text { organic, } \\
\text { dis- } \\
\text { solved } \\
\text { (mg/L } \\
\text { as C) }\end{array}$ \\
\hline 101 & $08-23-78$ & ND & 550 & 22 & -- & 80 & $<0.1$ & ND & $<1$ & -- & $<20$ & 1.9 \\
\hline 102 & $09-06-68$ & $\cdots$ & - & - & -- & -- & -- & -- & -- & -- & -- & -- \\
\hline 103 & $07-11-68$ & -- & -- & -- & -- & -- & -- & -- & -- & -- & -- & -- \\
\hline 104 & $08-23-78$ & $<20$ & 390 & 25 & - & 710 & $<.1$ & $\mathrm{ND}$ & $<1$ & -- & ND & 3.7 \\
\hline 105 & $09-06-68$ & -- & -- & -- & $\cdots$ & -- & -- & -- & -- & -- & $\cdots$ & -- \\
\hline 106 & $08-23-78$ & ND & 1,000 & 82 & -- & 160 & $<.1$ & ND & $<1$ & -- & 220 & 3.4 \\
\hline 107 & $05-08-80$ & -- & $<10$ & -- & -- & 370 & -- & -- & -- & -- & -- & -- \\
\hline 108 & $03-25-81$ & -- & -- & -- & -- & -- & -- & -- & -- & -- & -- & -- \\
\hline 109 & $08-01-80$ & -- & 640 & -- & -- & 140 & -- & $\cdots$ & -- & -- & -- & $\cdots$ \\
\hline 110 & $08-23-78$ & ND & 80 & 31 & -- & 170 & $<.1$ & ND & $<1$ & -- & ND & 4.6 \\
\hline 111 & $08-23-78$ & ND & 50 & 150 & -- & 250 & $<.1$ & ND & $<1$ & -- & ND & 4.2 \\
\hline 112 & $09-12-68$ & -- & -- & - & -- & $\cdots$ & -- & $\therefore$ & $\therefore$ & -- & - & -- \\
\hline 113 & $05-08-80$ & $\cdots$ & 10,000 & -- & -- & 5,900 & $\cdots$ & -- & -- & -- & -- & -- \\
\hline 114 & $12-17-68$ & -- & -- & -- & -- & $\cdots$ & -- & -- & -- & -- & -- & -- \\
\hline 115 & $09-06-68$ & -- & -- & -- & -- & -- & -- & -- & -- & -- & -- & -- \\
\hline 116 & $09-06-68$ & -- & -- & -- & -- & -- & -- & -- & -- & -- & -- & -- \\
\hline 117 & $07-30-80$ & 4 & $<10$ & 0 & -- & 1 & .8 & -- & 0 & 0 & 50 & -- \\
\hline 118 & $08-06-68$ & -- & -- & -- & -- & -- & -- & -- & -- & -- & -- & -- \\
\hline 119 & $07-31-80$ & -- & 160 & -- & -- & 1,800 & -- & -- & -- & -- & -- & -- \\
\hline 120 & $07-30-80$ & $\cdots$ & 20 & -- & $\cdots$ & 1 & $\cdots$ & -- & -- & -- & -- & -- \\
\hline 121 & $07-29-80$ & -- & 40 & -- & -- & 10 & -- & -- & -- & -- & -- & -- \\
\hline 122 & $09-06-68$ & -- & -- & -- & -- & -- & -- & -- & -- & -- & -- & $\cdots$ \\
\hline 123 & $08-21-68$ & -- & -- & -- & -- & -- & -- & -- & -- & -- & -- & -- \\
\hline 124 & $10-09-75$ & -- & 130 & -- & 320 & $<10$ & $<.5$ & -- & $<1$ & -- & $<20$ & -- \\
\hline 125 & $01-25-76$ & -- & 50 & -- & -- & 20 & -- & -- & -- & -- & -- & -- \\
\hline 126 & $04-20-76$ & -- & 60 & -- & -- & $<10$ & -- & -- & -- & -- & -- & -- \\
\hline 127 & $10-09-75$ & -- & 220 & -- & 320 & 20 & $<.5$ & $\cdots$ & $<1$ & -- & $<20$ & -- \\
\hline 128 & $01-25-76$ & -- & 150 & -- & -- & 20 & -- & -- & -- & -- & -- & -- \\
\hline 129 & $04-20-76$ & -- & 250 & -- & -- & $<10$ & -- & -- & -- & -- & -- & -- \\
\hline 130 & $07-29-80$ & 4 & 50 & 0 & -- & 9 & 1.0 & -- & 0 & 0 & 20 & -- \\
\hline 131 & $10-23-75$ & -- & $<10$ & -- & 100 & 5 & $<.5$ & -- & $<1$ & -- & 8 & -- \\
\hline
\end{tabular}


Table 5.--Water-quality information from selected wells and springs in the Conejos River subbasin in Colorado

[mo/d/yr, month/day/year; gal/min, gallons per minute; C, degree Celsius; $\mu \mathrm{S} / \mathrm{cm}$, microsiemens per centimeter at $25^{\circ} \mathrm{C} ; \mathrm{mg} / \mathrm{L}$, milligrams per liter; $\mu \mathrm{g} / \mathrm{L}$, micrograms per liter; TU, tritium unit; --, no data]

\begin{tabular}{|c|c|c|c|c|c|c|c|c|c|c|c|}
\hline $\begin{array}{l}\text { Site- } \\
\text { obser- } \\
\text { vation } \\
\text { letter } \\
\text { (figs. } 6 \\
\text { and } 11 \text {, } \\
\text { table } 3 \text { ) }\end{array}$ & Latitude & Longitude & $\begin{array}{l}\text { Sequence } \\
\text { number }\end{array}$ & Local & 1 identifier & $\begin{array}{l}\text { Date of } \\
\text { sample } \\
\text { (mo/d/yr) }\end{array}$ & $\begin{array}{l}\text { Depth } \\
\text { to water } \\
\text { (feet) }\end{array}$ & $\begin{array}{l}\text { Temper- } \\
\text { ature } \\
\left({ }^{\circ} \mathrm{C}\right)\end{array}$ & $\begin{array}{l}\text { Spe- } \\
\text { cific } \\
\text { conduct- } \\
\text { ance, } \\
\text { field } \\
(\mu \mathrm{S} / \mathrm{cm})\end{array}$ & $\begin{array}{l}\mathrm{pH}, \\
\text { field } \\
\text { (stand- } \\
\text { ard } \\
\text { units) }\end{array}$ & $\begin{array}{c}\text { Depth } \\
\text { to } \\
\text { water } \\
\text { (feet) }\end{array}$ \\
\hline $\begin{array}{l}\text { A } \\
\text { B } \\
\text { C } \\
\text { D } \\
\text { E }\end{array}$ & $\begin{array}{l}37^{\circ} 11^{\prime} 45^{\prime \prime} \\
37^{\circ} 16^{\prime} 48^{\prime \prime} \\
37^{\circ} 16^{\prime} 48^{\prime \prime} \\
37^{\circ} 17^{\prime} 41^{\prime \prime} \\
37^{\circ} 18^{\prime} 07^{\prime \prime}\end{array}$ & $\begin{array}{l}105^{\circ} 52^{\prime} 30^{\prime \prime} \\
105^{\circ} 48^{\prime} 34^{\prime \prime} \\
105^{\circ} 48^{\prime} 34^{\prime \prime} \\
105^{\circ} 47^{\prime} 05^{\prime \prime} \\
105^{\circ} 47^{\prime} 45^{\prime \prime}\end{array}$ & $\begin{array}{l}01 \\
00 \\
00 \\
00 \\
00\end{array}$ & $\begin{array}{l}\text { Well } \\
\text { McInt } \\
\text { McInt } \\
\text { Dexte } \\
\text { Well }\end{array}$ & $\begin{array}{l}\text { NA03401016AAA } \\
\text { ire Spring } \\
\text { =ire Spring } \\
\text { er Warm Spring } \\
\text { NA03501105CAC }\end{array}$ & $\begin{array}{l}5 / 04 / 84 \\
5 / 04 / 84 \\
5 / 04 / 84 \\
5 / 03 / 84 \\
5 / 03 / 84\end{array}$ & $\begin{array}{l}575 \\
-- \\
-- \\
-- \\
940\end{array}$ & $\begin{array}{l}12.0 \\
16.0 \\
16.0 \\
21.0 \\
24.0\end{array}$ & $\begin{array}{l}135 \\
165 \\
215 \\
205 \\
225\end{array}$ & $\begin{array}{l}7.9 \\
7.7 \\
7.8 \\
8.2 \\
8.2\end{array}$ & $\begin{array}{l}575 \\
-- \\
-- \\
-- \\
940 \\
\end{array}$ \\
\hline $\begin{array}{l}\text { Site- } \\
\text { obser- } \\
\text { vation } \\
\text { letter }\end{array}$ & $\begin{array}{c}\text { Alka- } \\
\text { linity } \\
(\mathrm{mg} / \mathrm{L} \text { as } \\
\left.\mathrm{CaCO}_{3}\right)\end{array}$ & $\begin{array}{l}\text { Calcium, } \\
\text { dissolved } \\
(\mathrm{mg} / \mathrm{L} \\
\text { as Ca) }\end{array}$ & \multicolumn{2}{|c|}{$\begin{array}{l}\text { Magnesium, } \\
\text { dissolved } \\
\text { (mg/L } \\
\text { as } \mathrm{Mg})\end{array}$} & $\begin{array}{l}\text { Potassium, } \\
\text { dissolved } \\
(\mathrm{mg} / \mathrm{L} \\
\text { as K) }\end{array}$ & \multicolumn{2}{|c|}{$\begin{array}{l}\text { Sodium, } \\
\text { dissolved } \\
\text { (mg/L } \\
\text { as } \mathrm{Na})\end{array}$} & $\begin{array}{l}\text { Chloride, } \\
\text { dissolved } \\
\text { (mg/L } \\
\text { as Cl) }\end{array}$ & $\begin{array}{c}\text { Fluoride, } \\
\text { dissolved } \\
\text { (mg/L } \\
\text { as F) }\end{array}$ & \multicolumn{2}{|c|}{$\begin{array}{r}\text { Sulfate, } \\
\text { dissolved } \\
(\mathrm{mg} / \mathrm{L} \\
\left.\text { as } \mathrm{SO}_{4}\right)\end{array}$} \\
\hline $\begin{array}{l}\text { A } \\
\text { B } \\
\text { C } \\
\text { D } \\
\text { E }\end{array}$ & $\begin{array}{l}75 \\
75 \\
62 \\
77 \\
84\end{array}$ & $\begin{array}{l}19 \\
20 \\
22 \\
12 \\
11\end{array}$ & \multicolumn{2}{|c|}{$\begin{array}{l}3.4 \\
3.3 \\
2.7 \\
2.0 \\
5.0\end{array}$} & $\begin{array}{l}1.8 \\
3.7 \\
4.8 \\
7.0 \\
7.9 \\
\end{array}$ & \multicolumn{3}{|r|}{$\begin{array}{l}0.7 \\
1.4 \\
1.3 \\
2.3 \\
3.4\end{array}$} & $\begin{array}{r}0.2 \\
.3 \\
.3 \\
.7 \\
.9 \\
\end{array}$ & \multicolumn{2}{|r|}{$\begin{array}{l}1.9 \\
16 \\
30 \\
28 \\
29\end{array}$} \\
\hline $\begin{array}{l}\text { Site- } \\
\text { obser- } \\
\text { vation } \\
\text { letter }\end{array}$ & $\begin{array}{c}\text { Boron, } \\
\text { dissolved } \\
(\mu g / L \\
\text { as B })\end{array}$ & $\begin{array}{c}\text { Iron, } \\
\text { dissolved } \\
(\mu \mathrm{g} / \mathrm{L} \\
\text { as Fe })\end{array}$ & \multicolumn{3}{|c|}{$\begin{array}{c}\text { Manganese, } \\
\text { dissolved } \\
(\mu \mathrm{g} / \mathrm{L} \\
\text { as } \mathrm{Mn})\end{array}$} & $\begin{array}{c}\text { Hardness } \\
(\mathrm{mg} / \mathrm{L} \text { as } \\
\left.\mathrm{CaCO}_{3}\right)\end{array}$ & \multicolumn{2}{|c|}{$\begin{array}{c}\text { Hardness, } \\
\text { noncarbonate } \\
(\mathrm{mg} / \mathrm{L} \text { as } \\
\left.\mathrm{CaCO}_{3}\right)\end{array}$} & $\begin{array}{c}\text { Nitrogen } \\
\mathrm{NO}_{2}+\mathrm{NO}_{3} \\
\text { dissolved } \\
(\mathrm{mg} / \mathrm{L} \text { as } \mathrm{N})\end{array}$ & \multicolumn{2}{|c|}{$\begin{array}{c}\text { Phosphorus, } \\
\text { ortho, } \\
\text { dissolved } \\
\text { (mg/L as P) }\end{array}$} \\
\hline $\begin{array}{l}\mathrm{A} \\
\mathrm{B} \\
\mathrm{C} \\
\mathrm{D} \\
\mathrm{E}\end{array}$ & $\begin{array}{l}20 \\
30 \\
30 \\
70 \\
90\end{array}$ & $\begin{array}{r}6 \\
81 \\
13 \\
11 \\
8 \\
\end{array}$ & $\begin{array}{r}<1 . \\
1 . \\
<1 . \\
2 . \\
<1 .\end{array}$ & & $\begin{array}{l}38 \\
50 \\
54 \\
69 \\
72 \\
\end{array}$ & $\begin{array}{l}61.0 \\
64.0 \\
66.0 \\
38.0 \\
48.0\end{array}$ & $\begin{array}{r}0.0 \\
.0 \\
4.0 \\
.0 \\
.0\end{array}$ & & $\begin{array}{r}0.36 \\
.37 \\
.34 \\
.37 \\
.44\end{array}$ & & $\begin{array}{l}.02 \\
.02 \\
.01 \\
.02 \\
.01 \\
\end{array}$ \\
\hline \multicolumn{2}{|c|}{$\begin{array}{l}\text { Site- } \\
\text { observation } \\
\text { letter }\end{array}$} & $\begin{array}{l}\text { Oxygen, } \\
\text { dissolved } \\
(\mathrm{mg} / \mathrm{L})\end{array}$ & \multicolumn{3}{|c|}{$\begin{array}{l}\text { Solids, sum of con- } \\
\text { stituents, dissolved } \\
(\mathrm{mg} / \mathrm{L})\end{array}$} & \multicolumn{2}{|c|}{$\begin{array}{l}\text { Sodium- } \\
\text { absorption } \\
\text { ratio }\end{array}$} & \multicolumn{2}{|c|}{$\begin{array}{l}\text { Percent } \\
\text { sodium }\end{array}$} & \multicolumn{2}{|c|}{$\begin{array}{l}\text { Tritium } \\
\text { (total } \\
\left.\text { TU as }{ }^{3} \mathrm{~T}\right)\end{array}$} \\
\hline \multicolumn{2}{|l|}{$\begin{array}{l}\text { A } \\
\text { B } \\
\text { C } \\
\text { D } \\
\text { E }\end{array}$} & $\begin{array}{l}7.8 \\
5.6 \\
6.2 \\
-- \\
--\end{array}$ & & $\begin{array}{l}11 \\
15 \\
16 \\
19 \\
21\end{array}$ & $\begin{array}{l}8 \\
3 \\
5 \\
7 \\
4\end{array}$ & $\begin{array}{r}0.3 \\
.6 \\
.6 \\
2.1 \\
2.2\end{array}$ & & $\begin{array}{l}17 \\
26 \\
25 \\
56 \\
55\end{array}$ & $\begin{array}{l}17 \\
26 \\
25 \\
56 \\
55\end{array}$ & & $\begin{array}{l}.75 \\
.66 \\
.-\end{array}$ \\
\hline
\end{tabular}

